PR

6015

H98S64

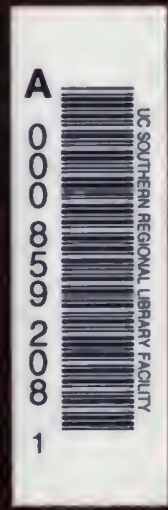

$\therefore \quad 860$ 

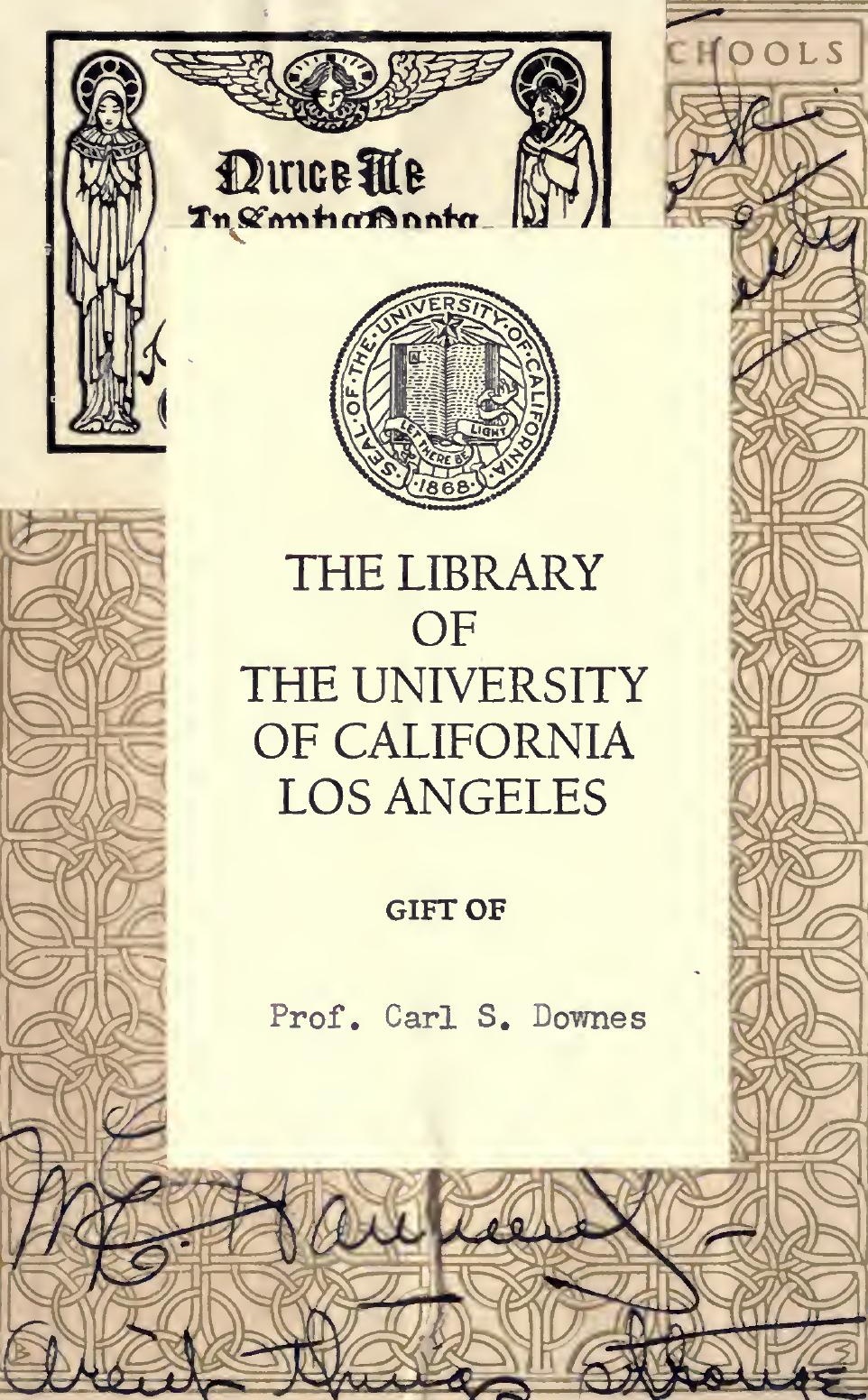


\section{SELECTIONS FROM}

\section{H UXLEY}

EDITED BY

\section{ALPHONSO SMITH}

EDGAR ALLAN POE PROFESSOR OF ENGLISH IN THE UNIVERSITY OF VIRGINIA

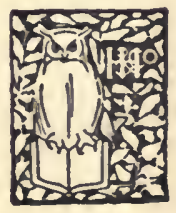

NEW YORK HENRY HOLT AND COMPANY

I9I2 
Copyright, igiz, BY HENRY HOLT AND COMPANY 


\section{$P R$ \\ 6015 \\ H98S64}

\section{CONTENTS}

INTRODUCTION

PAGE

I. Huxley's Life and Work . . . . . . . vii

II. The Selections . . . . . . . . . xix

Descriptive Bibliography • • • • • • • - $\mathbf{x x v}$

Selections

Autobiography . . . : . . . . . 3

Letters . • • • • • • • • • • 16

On the Advisableness of Improving Natural Knowledge 28

A Liberal Education: and where to find it . . . 47

On a Piece of Chalk . . . . . . . . 74

Science and Art in Relation to Education . . . . ro3

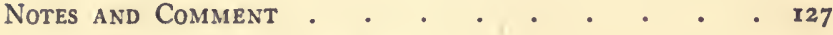

Questions AND Topics For Study . . . . . . 146

Portrait of Huxley . . . . . . . . Frontispiece

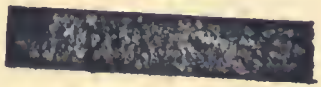

1734619 
Digitized by the Internet Archive in 2007 with funding from Microsoft Corporation 


\section{INTRODUCTION}

\section{I \\ HUXLEY'S LIFE AND WORK}

IN a letter written to his sister in 1850 Huxley said: "I don't know and I don't care whether I shall ever be what is called a great man. I shall leave my mark somewhere, and it shall be clear and distinct-

T. H. H.-his mark.

and free from the abominable blur of cant, humbug, and self-seeking which surrounds everything in this present world - that is to say, supposing that I am not already unconsciously tainted myself, a result of which I have a morbid dread." We shall not debate the question whether Huxley was "what is called a great man," but no one familiar with his life and work can doubt for a moment that he has left his mark or that it is "clear and distinct." $\mathrm{He}$ had the good fortune to find his work early-a rare piece of good fortune-and never to doubt that he had found it. For just fifty years, from 1845 to 1895 , he wrought happily and usefully. When he died he had the satisfaction of knowing that his fame was secure and that he had added to the knowledge and welfare of his fellow-men.

Thomas Henry Huxley was born of good but poor parents at Ealing, a village not far from London, on May 4, 1825. He told Charles Kingsley that he was "kicked into the world a boy without guide or training, or with worse than none." He tells us in his Autobiography of 
the wretched little school that he attended, and in after years used to say that "he had two years of a Pandemonium of a school (between eight and ten) and after that neither help nor sympathy in any intellectual direction till he reached manhood."

He was always fond of reading and used to browse at random in his father's library. "When a boy of twelve," his son and biographer writes, "he used to light his candle before dawn, pin a blanket around his shoulders, and sit up in bed to read Hutton's Geology." His tastes were scientific but he did not confine his reading to science. He was still a child when he read Sir William Hamilton's Philosophy of the Unconditioned, but his comment on it is not that of a child: "It stamped on my mind the strong conviction that on even the most solemn and important of questions, men are apt to take cunning phrases for answers."

But Carlyle had the most lasting influence upon him during these formative years. It was interest in Carlyle that led him to study German, just as at the age of fiftythree he learned Greek so that he might read Aristotle in the original. During these years he also taught himself French and Italian. Of Carlyle's Sartor Resartus he wrote: "It led me to know that a deep sense of religion was compatible with the entire absence of theology." Carlyle taught him also a hatred of shams and a love of uncompromising truthfulness that remained a passion with him as long as he lived. "If wife and child," he said, "and name and fame were all lost to me, one after another, still I would not lie. . . The longer I live, the more obvious it is to me that the most sacred act of a man's life is to say and to feel, 'I believe such and such to be true.' All the greatest rewards and all the heaviest penalties of existence cling about that act." 
After serving as assistant under one or two physicians he received an appointment in 1842 to one of the free scholarships at the Charing Cross Hospital in London. He was now seventeen years old and his application for admission to Charing Cross certified that " $\mathrm{He}$ has a fair knowledge of Latin, reads French with facility, and knows something of German. He has also made considerable progress in mathematics, having, as far as he has advanced, a thorough not a superficial knowledge of the subject." In 1845 he won his M.B. (Bachelor of Medicine) at the University of London and also a gold medal for proficiency in anatomy and physiology. He tells us also that in this year he published his first scientific paper, "a very little one," in the Medical Gazette; but he does not tell us that this paper announced a permanent contribution to anatomy. The youthful investigator had found a hitherto undiscovered membrane in the root of the human hair and this membrane is now known as "Huxley's layer."

In December of 1846 Huxley left England as assistant surgeon on board her Majesty's ship, the Rattlesnake. The cruise lasted four years, three being spent in Australian waters. It was on a voyage of this sort that Charles Darwin and Joseph Dalton Hooker had laid the foundations of their scientific careers. Indeed we can hardly imagine a better scientific training than such a voyage afforded. The young scientist had to depend largely on his own resources. He had to collect and dissect without the aid of many books. He was confronted daily by forms of marine life either unknown or at least unclassified. But it was just the discipline that Huxley needed and wanted. When he returned in 1850 , Edward Forbes, the best English authority on star-fishes, examined his collection and wrote to him, saying: "I can say without exaggeration that more important or more complete 
zoölogical researches have never been conducted during any voyage of discovery in the southern hemisphere. The course you have taken of directing your attention mainly to impreservable creatures, and to those orders of the animal kingdom respecting which we have least information, and the care and skill with which you have conducted elaborate dissections and microscopic examinations of the curious creatures you were so fortunate as to meet with, necessarily gives a peculiar and unique character to your researches, since thereby they fill up gaps in our knowledge of the animal kingdom. This is more important, since such researches have been almost always neglected during voyages of discovery."

But Huxley's cruise in Australian waters had another result. Three weeks after his return to England, he wrote to his sister, Mrs. J. G. Scott, who was then living in Nashville, Tennessee: "I have a woman's element in me. I hate the incessant struggle and toil to cut one another's throat among us men, and I long to be able to meet with some one in whom I can place implicit confidence, whose judgment I can respect, and yet who will not laugh at my most foolish weaknesses, and in whose love I can forget all care. All these conditions I have fulfilled in Nettie. With a strong natural intelligence, and knowledge enough to understand and sympathize with my aims, with the firmness of a man when necessary, she combines the gentleness of a very woman and the honest simplicity of a child, and then she loves me well, as well as I love her, and you know I love but few-in the real meaning of the word, perhaps, but two-she and you . . . The worst of it is I have no ambition, except as means to an end, and that end is the possession of a sufficient income to marry upon. I assure you I would not give two straws for all the honors and titles in the world. A worker I 
must always be-it is my nature-but if I had $£_{400}$ a year I would never let my name appear to anything I did or shall ever do. It would be glorious to be a voice working in secret and free from all those personal motives that have actuated the best."

The woman thus charmingly referred to was Miss Henrietta Anne Heathorn, whom he had met in Australia in 1848 . But not till 1855 could he write: "I terminate my Baccalaureate and take my degree of M.A. trimony (isn't that atrocious?) on Saturday, July 21." He had served as long for her as Jacob thought to serve for Rachel, but during their forty years of married life he found in her his best comforter and wisest counselor. What he said of her in 1848 he could say with added assurance in 1895: "I never met with so sweet a temper, so self-sacrificing and affectionate a disposition, or so pure and womanly a mind." Twelve years after his marriage he was visited by a German, Dr. Dohrn, who wrote: "I have been reading several chapters of Mill's Utilitarianism and have found the word 'happiness' occurring very often. If $I$ had to give anybody a definition of this much debated word, I should only say, 'Go and see the Huxley family.'

His life was very busy now, but he found time in the summer of 1876 to visit America and to deliver the inaugural address at the opening of the Johns Hopkins University in Baltimore. He received an enthusiastic welcome, and the letters that he sent from America are among the most interesting that he ever wrote. The little tug-boats in the harbor of New York seemed especially to interest him. "If I were not a man," he said, "I think I should like to be a tug." On the material greatness of America he remarked: "I cannot say that I $\mathrm{am}$ in the slightest degree impressed by your bigness or 
your material resources, as such. Size is not grandeur; territory does not make a nation. The great issue, about which hangs a true sublimity and the terror of overhanging fate, is, What are you going to do with all these things? The one condition of success, your sole safeguard, is the moral worth and intellectual clearness of the individual citizen. Education cannot give these, but it can cherish them and bring them to the front in whatever station of society they are to be found, and the universities ought to be and may be the fortresses of the higher life of the nation."

Huxley was never very strong. In 1888 he wrote to a friend: "Dame Nature has given me a broad hint that I have had my innings, and, for the rest of my time, must be content to look on at the players." The essays alone, however, that he wrote after 1888 would have given him a place among the intellectual leaders of. the century. Three days before his death he writes as jauntily as ever: "At present I don't feel at all like 'sending in my checks,' and without being over sanguine I rather incline to think that my native toughness will get the best of it." The end came quietly on June 29, 1895. At his request these lines, written by Mrs. Huxley, were inscribed upon his tombstone:

"Be not afraid, ye waiting hearts that weep;

For still He giveth His belovèd sleep, And if an endless sleep He wills, so best."

Of Huxley's busy career the Autobiography gives us only glimpses here and there. We learn from it, however, that his chief interests lay in "the working out of the wonderful unity of plan in the thousands and thousands of diverse living constructions" of nature, and in promoting "the application of scientific methods of investigation 
to all the problems of hife." In other words, Huxley spent his life in forwarding science and education. He was not only a naturalist but a sociologist. Was he greater, now, in discovery or in application? He was great in both but greater, we think, in the latter. Let us see.

As a scientific discoverer, Huxley can never rank with Newton or Darwin. But if these are immortals of the first rank, Huxley is as certainly an immortal of the second rank. It is interesting to see how eager Darwin was to know how The Origin of Species, Darwin's greatest work, would impress Huxley. Darwvin called Huxley his "general agent," and Huxley called himself "Darwin's bulldog." The Origin of Species appeared in 1859 and Darwin wrote: "If I can convert Huxley I shall be content." With one or two reservations, Huxley was converted and championed the book the rest of his life. But this association with Darwin and with Darwin's work has caused most readers to overlook Huxley's own contributions to science. These may be summarized in untechnical language under five heads.

We have already seen that at the age of tiventy Huxley discovered an unknown layer in the human hair now known by his name. More important, however, than "Huxley's layer" was his paper published in 1849 on The Anatomy and the Affinities of the Family of the Medusa. The medusæ are jelly-fishes and their classification had been in a state of chaos till Huxley succeeded in finding "unity of plan" not only in them but in the entire family to which they belong. He discovered that all medusæ are built up of two cell-layers, two "foundationmembranes," inclosing a stomach cavity. He did not know then how his discovery would help to prepare the way for Darwin's work. Scientists, however, knew al- 
ready that all backboned animals passed through certain regular and definite stages in their progress from the embryo to the adult state, but Huxley showed that all backboned animals passed through the medusæ stage, that is, they also exhibited two corresponding "foundationmembranes." He had thus laid a foundation on which other scientists were soon to build.

Another original view appeared in The Cell Theory (1853). Before this time scientists had believed, as many still believe, the cell to be the ultimate life-unit. In other words, the cell was life reduced to its lowest terms. It was the smallest particle of life just as the atom is considered the smallest particle of matter. Huxley contended that the real life-element was not the cell but protoplasm, that protoplasm was the raw stuff that built up the cell just as the cell built up the body. He compared protoplasm to the sea, cells to the numberless shells and weeds that the sea tosses up. While this theory has not been universally accepted it has not been conclusively overthrown.

But perhaps Huxley's best claim to popular recognition as a scientist is that he discovered, or at least was the first to announce, the pedigree of the horse. In 1870 he said that if there were strong reasons to believe that our modern one-toed horse had a remote ancestor with three toes, there were still stronger reasons to believe that he had a still more remote ancestor with five toes. When Huxley visited America in 1876, Professor O. C. Marsh of Yale University showed him the fossil of a horse with four complete toes on the front leg and three on the hind leg. Huxley now re-affirmed his theory of a five-toed horse, "in which, if the doctrine of evolution is wellfounded, the whole series must have taken its origin." Two months later Professor Marsh actually discovered the 
fossil of an American horse with five toes. The honor of the find belongs, therefore, by discovery to Professor Marsh, and only by prophecy to Huxley.

One other contribution to anatomy may be said to close Huxley's achievements as a discoverer. It was a generally accepted belief that the skull was merely the expanded backbone. A German naturalist, named Oken, while walking in the Harz Mountains, had picked up the dried skull of a sheep, and it suddenly occurred to him that this skull was nothing but a series of expanded vertebræ molded together. Oken's view was accepted in England till Huxley overthrew it. He examined the skulls of fishes, beasts, and men, and found that Oken's theory was not borne out by the facts. "It may be true," he said, "that there is a primitive identity of structure between the spinal or vertebral column and the skull, but it is no more true that the adult skull is a modified vertebral column than it would be to affirm that the vertebral column is a modified skull."

Let us turn now to Huxley's services in the cause of education. If Darwin outranks him as a scientist, he outranks Darwin just as incontestably as an educator. His interests were more varied than Darwin's, his perceptions quicker, his personality more vigorous, his human sympathies broader, and his command of the resources of the English language far superior. If Huxley had done nothing more than contribute to modern thought the definition of a liberal education found on pages 54 and 55 of this book, he would be remembered at least to the extent of that stimulating paragraph. But he did far more. He talked and wrote and worked unceasingly to make his educational ideals prevail. These ideals are scattered through his essays and lectures and letters, but the fundamentals may be easily summarized. 
The function of education as a national concern should be, he contended, to provide "a ladder reaching from the gutter to the university, along which every child in the three kingdoms should have the chance of climbing as far as he was fit to go." All children, but especially townbred children, should be taught the simpler forms of gymnastics. After reading, writing, and arithmetic, the emphasis should be put upon one or more of the natural sciences, because in these the faculties of observation and inquiry are disciplined. The value of drawing, he thought, could not be exaggerated, "because it gives the means of training the young in attention and accuracy, the two things in which all mankind are more deficient than in any other mental quality whatever."

Women are not excluded from his scheme of education but expressly included. "The mind of the average girl," he wrote, " is less different from that of the average boy, than the mind of one boy is from that of another; so that whatever argument justifies a given education for all boys, justifies its application to girls as well. So far from imposing artificial restriction upon the acquirement of knowledge by women, throw every facility in their way. . . . They will be none the less sweet for a little wisdom; and the golden hair will not curl less gracefully outside the head by reason of there being brains within. . . . Let them, if they so please, become merchants, barristers, politicians. Let them have a fair field, but let them understand as the necessary correlative, that they are to have no favor. . . . And the result? Women will find their place and it will neither be that in which they have been held, nor that to which some of them aspire."

Literature should have an important place because "an exclusively-scientific training will bring about a mental twist as surely as an exclusively literary training. For 
literature is the greatest of all sources of refined pleasure, and there is scope enough for the purposes of liberal education in the study of the rich treasures of our own language alone. . . . I have said before, and I repeat it here, that if a man cannot get literary culture of the highest kind out of his Bible, and Chaucer, and Shakespeare, he cannot get it out of anything, and I would assuredly devote a very large portion of the time of every English child to the careful study of models of English writing of such varied and wonderful kind as we possess, and, what is still more important, and still more neglected, the habit of using that language with precision, with force, and with art."

Moral training should not be neglected. Since each child is " a member of a social and political organization of great complexity, and has, in future, to fit himself into that organization, or be crushed by it, it is needful not only that boys and girls should be made acquainted with the elementary laws of conduct, but that their affections should be trained so as to love with all their hearts that conduct which tends to the attainment of the highest good for themselves and their fellow-men, and to hate with all their hearts that opposite course of action which is fraught with evil." As his own children were taught the Bible, he advocated its use in all elementary schools. He saw no way in which "the religious feeling, which is the essential basis of conduct, was to be kept up, in the present utterly chaotic state of opinion, without the use of the Bible."

Then follows this eloquent passage: "Consider the great historical fact that, for three centuries, this book has been woven into the life of all that is best and noblest in English history; that it has become the national epic of Britain, and is as familiar to noble and simple, from John-o'- 
Groat's House to Land's End, as Dante and Tasso once were to the Italians; that it is written in the noblest and purest English, and abounds in exquisite beauties of mere literary form; and, finally, that it forbids the veriest hind who never left his village to be ignorant of the existence of other countries and other civilizations, and of a great past, stretching back to the furthest limits of the oldest nations in the world. By the study of what other book could children be so much humanized and made to feel that each figure in that vast historical procession fills, like themselves, but a momentary space in the interval between two eternities; and earns the blessings or the curses of all time, according to its effort to do good and hate evil, even as they also are earning their payment for their work?"

Huxley's success as an educational leader was due not to natural gifts as a speaker or writer but to depth of conviction, to steady growth, and to persistent self-improvement. "I have a great love and respect for my native tongue," he wrote in 1891, "and take great pains to use it properly. Sometimes I write essays half-a-dozen times before I can get them into the proper shape; and I believe I become more fastidious as I grow older." His creed was: "Say that which has to be said in such language that you can stand cross-examination on each word."

His best writing is in his letters, where his humor, his abounding vigor, his nimble fancy, his quick feeling for analogy, his wide command of illustration, his passion for directness find their amplest exhibition. He brought into his writings the same "unity of plan" which he found "in the thousands and thousands of diverse living constructions" that surrounded him. The force and vividness of his style find their explanation in the fact that he 
was always an investigator and thus always a learner. No man could vivify and humanize the claims of science as Huxley has done unless he was himself invigorated by a sense of daily growth and achievement. The lesson of his style at last is not, Study science that you may learn to write clearly, but, Think for yourself that your message may come with force, directness, and conviction.

\section{II}

\section{THE SELECTIONS}

THE selections that follow have been chosen with three ends in view: ( $I$ ) To throw light on the character and services of Huxley; (2) to stimulate an interest in the principles and problems of modern science; and - (3) to furnish examples of clear, flexible, forceful prose. It will be seen that the Autobiography is an admirable example of narration, that the Letters furnish still more interesting examples of both narration and description, and that the Essays confine themselves almost wholly to exposition and argumentation. The selections exemplify, therefore, the four literary types or kinds of discourse.

What follows is intended to serve as an introduction not only to the selections themselves but also to the Notes and Comment and to the Questions and Topics for Study.

1. Autobiography. On March 2, 1889, Huxley wrote to his wife: "A man who is bringing out a series of portraits of celebrities, with a sketch of their career attached, has bothered me out of my life for something to go with my portrait, and to escape the abominable bad taste of some of the notices, I have done that. I shall show it to you before it goes back to Engel in proof." 
To Engel he wrote: "You are really the most pertinaciously persuasive of men. When you first wrote to me, I said I would have nothing whatever to do with anything you might please to say about me, that I had a profound objection to write about myself, and that I could not see what business the public had with my private life. I think I even expressed to you my complete sympathy with Dr. Johnson's desire to take Boswell's life when he heard of the latter's occupation with his biography.

"Undeterred by all this, you put before me the alternative of issuing something that may be all wrong, unless I furnish you with something authoritative; I do not say all right, because autobiographies are essentially works of fiction, whatever biographies may be. So I yield, and send you what follows, in the hope that those who find it to be mere egotistical gossip will blame you and not me."

The Autobiography was written, then, in 1889 , six years before Huxley's death. It was published in Method and Results (1893), which is volume one of Huxley's Collected Essays. Huxley was often urged to write a longer sketch of his life, but seemed to think it not worth the time. His best autobiography is to be found in the letters published in The Life and Letters of Thomas Henry Huxley, by his son, Leonard Huxley (American edition, 2 volumes, New York, I901).

2. LetTers. These letters, dating from 1852 to 1892 , are really a continuation of the Autobiography, no form of literature being as truly autobiographic as the letter. They present Huxley the man, Huxley the scientist, Huxley the public-spirited citizen. The frank expression of his hopes and ideals, the impressions made upon him by the funerals of the Duke of Wellington and Tennyson, his immediate recognition of the significance of Darwin's great work, his interesting description of the 
day spent on Mount Vesuvius, his magnanimous estimate of Pasteur's services, the sturdy common sense of his advice to a young man-all these supplement the Autobiography at vital points. The style of these letters is notable, too, for its freedom and flexibility, and for a certain rapidity of thought which Huxley said he owed to his mother.

3. On the Advisableness of Improving Natural Knowledge. This lay sermon was delivered in St. Martin's Hall, London, January 7, 1866. It was published in Lay Sermons, Addresses, and Reviews (1870), and republished in the first volume of Collected Essays. Huxley had spoken in St. Martin's Hall twelve years before on The Educational Value of the Natural History Sciences. The earlier address marked the beginning of Huxley's persistent endeavor to secure for science its rightful place in the educational system of England. The two addresses are strikingly alike. Of the first (now published in the third volume of Collected Essays) Huxley said: "It contains some crudities, which I repudiated when the lecture was first reprinted, more than twenty years ago; but it will be seen that much of what I have had to say, later on in life, is merely a development of the propositions enunciated in this early and sadly imperfect piece of work." One passage, at least, in the earlier essay deserves reproduction: "So far as I can arrive at any clear comprehension of the matter, science is not, as many would seem to suppose, a modification of the black art, suited to the tastes of the nineteenth century, and flourishing mainly in consequence of the decay of the Inquisition. Science is, I believe, nothing but trained and organized common sense, differing from the latter only as a veteran may differ from a raw recruit."

The address here reproduced might be called The 
Cultural vs. the Utilitarian Value of Science. It was not delivered to working men, and is hardly so popular in style or so practical in purpose as are the two following addresses. Its theme is the desirableness, not any particular method, of improving natural knowledge. The two leading thoughts-that science not only provides material comforts but (I) implants great ideas and (2) inculcates a higher type of ethics-are presented with great clearness. The second point, however, can hardly be considered as proved. The introduction to the essay proper, though a trifle long, is a model of its kind.

4. A Liberal Education: and Where to Find It. This was the opening address that Huxley delivered as Principal of the South London Working Men's College on January 4, I868. It was published in Lay Sermons, Addresses, and Reviews (1870) and republished in the third volume of Collected Essays. This address differs radically in method from the preceding. It is a presentation by means of a carefully formulated definition. If the definition of the liberally educated man be conceded, where can such an education be found? What, then, is needed?

This lecture and the following, says Mr. Leonard Huxley, "seem to me to mark the maturing of his style into that mastery of clear expression for which he deliberately labored, the saying exactly what he meant, neither too much nor too little. . . Be clear, though you may be convicted of error. If you are clearly wrong, you will run up against a fact some time and get set right. If you shuffle with your subject, and study chiefly to use language which will give a loophole of escape either way, there is no hope for you. This was the secret of his lucidity." This may be the secret of Huxley's lucidity, but lucidity alone is not the distinguishing characteristic of Huxley's style. His style is more than lucid. Its 
lucidity is vitalized by conviction and enthusiasm.' These are personal or rather, emotional traits, while lucidity is purely intellectual. Euclid and Blackstone are lucid; Macaulay and Huxley are vivid.

Huxley began his lectures to working men in I 855. "I am sick of the dilettante class," he wrote, "and mean to try what I can do with these hard-handed fellows who live among facts." Only working men were admitted, though a clerk once secured admission by calling himself a "driver." He was in fact a "quill-driver." The attendance and attention were equally gratifying, and Huxley exerted himself to the utmost to make these lectures a power for right thinking and right living. They represent him at his best in the spoken presentation of scientific truth.

5. On a Piece of Chalk. This lecture was delivered to the working men of Norwich during the meeting of the British Association in 1868. It was published in Lay Sermons, Addresses, and Reviews (1870), and republished in the eighth volume of Collected Essays. An interesting reference to Mrs. Huxley's good judgment is made by Huxley in connection with the proof-sheets of this lecture. He wrote to her from Norwich, August 23, I866: "I met Grove who edits Macmillan, at the soirée. He pulled the proof of my lecture out of his pocket and said: 'Look here, there is one paragraph in your lecture I can make neither top nor tail of. I can't understand what it means.' I looked to where his finger pointed, and behold it was the paragraph you objected to when I read you the lecture on the seashore! I told him, and said I should confess, however set up it might make you." "The address is noteworthy," says Mr. J. R. Ainsworth Davis, "in a variety of ways. For one thing it marks the increasing interest which men of science were 
beginning to take in deep-sea life, and which culminated in the equipment and despatch of the Challenger expedition towards the end of 1872." Interest in deep-sea problems, it may be said, had been greatly stimulated by the publication in 1855 of Matthew Fontaine Maury's Physical Geography of the Sea. This book was reprinted in England, where it passed through more than twenty editions. Huxley's address is noteworthy also as a perfect example of how a thinker can take a seemingly trivial subject and make it "a window into the infinite." Huxley's Piece of Chalk belongs with Tennyson's Flower in the Crannied Wall.

6. On Science and ARt in Relation to EducaTron. This lecture was delivered at a meeting of the Liverpool Institution in 1882 and published in the third volume of Collected Essays. It forms a fitting conclusion to our selections because Huxley here summarizes his views about education, defends his position against the charge of one-sidedness, re-affirms what he has said about science, and then talks interestingly and helpfully about literature in general, about grammar, drawing, English literature in particular, English composition, the value of translations-in fact, "all the essentials of education for an English child."

In simplicity of style, in maturity of thought, in range and variety of topics discussed, in autobiographic significance, in all the elements of clear and forceful exposition, this lecture outranks (in the edifor's opinion) all that have preceded it. It is, therefore, more than a conclusion to our selections: it is, in its way, a summary and a culmination. 


\section{DESCRIPTIVE BIBLIOGRAPHY}

THE best account of Huxley's life and varied activities is The Life and Letters of Thomas Henry Huxley, by his son, Leonard Huxley, in two volumes (London, 1900). The American edition is published by D. Appleton and Company, New York. This is one of the most interesting and stimulating of modern biographies. The whole modern scientific movement is reflected in it. A good book, made of gleanings from The Life and Letters, is Thomas Henry Huxley, by Edward Clodd, to whom some of the Huxley letters were written. This rolume is number eight in the Modern English Writers Series (Dodd, Mead and Company, New York, 1902). Clodd discusses Huxley in successive chapters as Man (the best chapter), Discoverer, Interpreter, Controversialist, and Constructor, there being no chapter on. Huxley the Writer. Chalmers Mitchell's Thomas Henry Huxley: $A$ Sketch of His Life and Work, and George Smalley's Mr. Huxley (published in Scribner's Magazine, October, 1895) are interesting presentations from different points of view, but they are less significant since the appearance of The Life and Letters. Fiske's Reminiscences of Huxley (in The Atlantic Monthly, February, I90I) is an eminently readable sketch of Huxley the man. The best sketch of Huxley, as a scientist, is Thomas H. Huxley, by J. R. Ainsworth Davis (London and New York, 1907). A complete list of obituary notices and personal reminiscences will be found in Poole's Index to Periodical 


\section{xxvi \\ Descriptive Bibliography}

Literature, Third Supplement, 1892-1896, and Fourth Supplement, 1897-1902.

Huxley's writings (essays, books, and scientific memoirs) form Appendix III in The Life and Letters and cover nineteen pages. Only the more significant books need be mentioned here. The dates are those of first editions:

1863. Evidence as to Man's Place in Nature.

The main contention of the book is thus summarized on page 67: "Without question, the mode of origin and the early stages of the development of man are identical with those of the animals immediately below him in the scale: without a doubt, in these respects, he is far nearer the Apes than the Apes are to the Dog."

1866. Lessons in Elementary Physiology.

This has proved the most popular of Huxley's books. Before his death it had passed into its fourth edition and been reprinted twenty-eight times.

1870. Lay Sermons, Addresses, and Reviews.

The fifteen chapters cover the years from 1854 to 1870. The volume includes the first three addresses reprinted in this book.

1877. American Addresses.

These addresses are good illustrations of how scientific accuracy may be not only joined with but vitalized by imagination. They discuss university education, creation, evolution, and methods of biological study. The lecture On the Study of Biology, though included in American Addresses, was not delivered until after Huxley's return to England.

I878. Hume.

Though this book appeared in the English Men of Letters Series, the emphasis is naturally upon Hume the philosopher. "It is assuredly one of Hume's greatest merits," says Huxley on page 63, "that he clearly recognized the fact that philosophy is based upon psychology; and that the inquiry into the contents and the operations of the mind must be conducted upon the same principles as a physical investiga- 


\section{Descriptive Bibliography}

tion, if what he calls the 'moral philosopher' would attain results of as firm and definite a character as those which reward the "natural philosopher.'"

1893. Evolution and Ethics.

Huxley's views on this subject are tersely stated in a letter of March 23, 1894: "There are two very different questions which people fail to discriminate. One is whether evolution accounts for morality, the other whether the principle of evolution in general can be adopted as an ethical principle. The first, of course, I advocate, and have constantly insisted upon. The second I deny, and reject all so-called evolutional ethics based upon it."

1893-1894. Collected Essays.

These nine volumes contain all of Huxley's writings that he cared to preserve, except the more technical papers.

1898-1903. The Scientific Memoirs of Thomas Henry Huxley. These, the purely scientific works of Huxley, were edited in five volumes by Michael Foster and E. Ray Lankester. 





\section{AUTOBIOGRAPHY}

\section{(1889)}

And when I consider, in one view, the many things ... which I have upon my hands, I feel the burlesque of being employed in this manner at my time of life. But, in another view, and taking in all circumstances, these things, as trifling as they may appear, no less than things of greater importance, 5 seem to be put upon me to do.-Bishop Butler to the Duchess of Somerset.

THE "many things" to which the Duchess's correspondent here refers are the repairs and improvements of the episcopal seat at Auckland. I doubt if the great ro apologist, greater in nothing than in the simple dignity of his character, would have considered the writing an account of himself as a thing which could be put upon him to do whatever circumstances might be taken in. But the good bishop lived in an age when a man might 15 write books and yet be permitted to keep his private existence to himself; in the pre-Boswellian epoch, when the germ of the photographer lay concealed in the distant future, and the interviewer who pervades our age was an unforeseen, indeed unimaginable, birth of time.

At present, the most convinced believer in the aphorism "Bene qui latuit, bene vixit," is not always able to act up to it. An importunate person informs him that his portrait is about to be published and will be accompanied by a biography which the importunate person proposes to 25 write. The sufferer knows what that means; either he 
undertakes to revise the "biography" or he does not. In the former case, he makes himself responsible; in the latter, he allows the publication of a mass of more or less fulsome inaccuracies for which he will be held responsible 5 by those who are familiar with the prevalent art of selfadvertisement. On the whole, it may be better to get over the "burlesque of being employed in this manner" and do the thing himself.

It was by reflections of this kind that, some years ago, I Io was led to write and permit the publication of the subjoined sketch.

I was born about eight o'clock in the morning on the 4th of May, 1825, at Ealing, which was, at that time, as quiet a little country village as could be found within I5 half-a-dozen miles of Hyde Park Corner. Now it is a suburb of London with, I believe, 30,000 inhabitants. My father was one of the masters in a large semi-public school which at one time had a high reputation. I am not aware that any portents preceded my arrival in this world, 20 but, in my childhood, I remember having a traditional account of the manner in which I lost the chance of an endowment of great practical value. The windows of my mother's room were open, in consequence of the unusual warmth of the weather. For the same reason, prob25 ably, a neighboring beehive had swarmed, and the new colony, pitching on the window-sill, was making its way into the room when the horrified nurse shut down the sash. If that well-meaning woman had only abstained from her ill-timed interference, the swarm might have settled on 30 my lips, and I should have been endowed with that mellifluous eloquence which, in this country, leads far more surely than worth, capacity, or honest work, to the highest places in church and state. But the opportunity was 


\section{Autobiography}

lost, and I have been obliged to content myself through life with saying what I mean in the plainest of plain language, than which, I suppose, there is no habit more ruinous to a man's prospects of advancement.

Why I was christened Thomas Henry I do not know; 5 but it is a curious chance that my parents should have fixed for my usual denomination upon the name of that particular Apostle with whom I have always felt most sympathy. Physically and mentally I am the son of my mother so completely-even down to peculiar movements of the ro hands, which made their appearance in me as I reached the age she had when I noticed them-that I can hardly find any trace of my father in myself, except an inborn faculty for drawing, which unfortunately, in my case, has never been cultivated, a hot temper, and that amount of 15 tenacity of purpose which unfriendly observers sometimes call obstinacy.

My mother was a slender brunette, of an emotional and energetic temperament, and possessed of the most piercing black eyes I ever saw in a woman's head. With 20 no more education than other women of the middle classes in her day, she had an excellent mental capacity. Her most distinguishing characteristic, however, was rapidity of thought. If one ventured to suggest she had not taken much time to arrive at any conclusion, she would say: 25 "I cannot help it, things flash across me." That peculiarity has been passed on to me in full strength; it has often stood me in good stead; it has sometimes played me sad tricks, and it has always been a danger. But, after all, if my time were to come over again, there is nothing 30 I would less willingly part with than my inheritance of mother wit.

I have next to nothing to say about my childhood. In later years my mother, looking at me almost reproachfully, 
would sometimes say, "Ah! you were such a pretty boy!" whence I had no difficulty in concluding that I had not fulfilled my early promise in the matter of looks. In fact, I have a distinct recollection of certain curls of 5 which I was vain, and of a conviction that I closely resembled that handsome, courtly gentleman, Sir Herbert Oakley, who was vicar of our parish, and who was as a god to us country folk, because he was occasionally visited by the then Prince George of Cambridge. I remember to turning my pinafore wrong side forwards in order to represent a surplice, and preaching to my mother's maids in the kitchen as nearly as possible in Sir Herbert's manner one Sunday morning when the rest of the family were at church. That is the earliest indication I can call to mind I5 of the strong clerical affinities which my friend Mr. Herbert Spencer has always ascribed to me, though I fancy they have for the most part remained in a latent state.

My regular school training was of the briefest, perhaps fortunately, for though my way of life has made me 20 acquainted with all sorts and conditions of men, from the highest to the lowest, I deliberately affirm that the society I fell into at school was the worst I have ever known. We boys were average lads, with much the same inherent capacity for good and evil as any others; but the

25 people who were set over us cared about as much for our intellectual and moral welfare as if they were babyfarmers. We were left to the operation of the struggle for existence among ourselves, and bullying was the least of the ill practices current among us. Almost the only 30 cheerful reminiscence in connection with the place which arises in my mind is that of a battle I had with one of my classmates, who had bullied me until I could stand it no longer. I was a very slight lad, but there was a wildcat element in me which, when roused, made up for lack of 
weight, and I licked my adversary effectually. However, one of my first experiences of the extremely rough-andready nature of justice, as exhibited by the course of things in general, arose out of the fact that I-the victorhad a black eye, while he-the vanquished-had none, so 5 that I got into disgrace and he did not. We made it up, and thereafter I was unmolested. One of the greatest shocks I ever received in my life was to be told a dozen years afterwards by the groom who brought me my horse in a stable-yard in Sydney that he was my quondam an- 10 tagonist. He had a long story of family misfortune to account for his position, but at that time it was necessary to deal very cautiously with mysterious strangers in New South Wales, and on inquiry I found that the unfortunate young man had not only been "sent out," but had under- 15 gone more than one colonial conviction.

As I grew older, my great desire was to be a mechanical engineer, but the fates were against this and, while very young, I commenced the study of medicine under a medical brother-in-law. But, though the In- 20 stitute of Mechanical Engineers would certainly not own me, I am not sure that I have not all along been a sort of mechanical engineer in partibus infidelium. I am now occasionally horrified to think how very little I ever knew or cared about medicine as the art of healing. The only 25 part of my professional course which really and deeply interested me was physiology, which is the mechanical engineering of living machines; and, notwithstanding that natural-science has been my proper business, I am afraid there is very little of the genuine naturalist in me. I 30 never collected anything, and species work was always a burden to me; what I cared for was the architectural and engineering part of the business, the working out of the wonderful unity of plan in the thousands and thou- 
sands of diverse living constructions, and the modifications of similar apparatuses to serve diverse ends. The extraordinary attraction I felt towards the study of the intricacies of living structure nearly proved fatal to me at 5 the outset. I was a mere boy-I think between thirteen and fourteen years of age-when $I$ was taken by some older student friends of mine to the first post-mortem examination I ever attended. All my life I have been most unfortunately sensitive to the disagreeables which Io attend anatomical pursuits, but on this occasion my curiosity overpowered all other feelings, and I spent two or three hours in gratifying it. I did not cut myself, and none of the ordinary symptoms of dissection-poison supervened, but poisoned I was somehow, and I remember I5 sinking into a strange state of apathy. By way of a last chance, I was sent to the care of some good, kind people, friends of my father's, who lived in a farmhouse in the heart of Warwickshire. I remember staggering from my bed to the window on the bright spring morning after my 20 arrival, and throwing open the casement. Life seemed to come back on the wings of the breeze, and to this day the faint odor of wood-smoke, like that which floated across the farm-yard in the early morning, is as good to me as the "sweet south upon a bed of violets." I soon re25 covered, but for years I suffered from occasional paroxysms of internal pain, and from that time my constant friend, hypochondriacal dyspepsia, commenced his half century of co-tenancy of my fleshly tabernacle.

Looking back on my "Lehrjahre," I am sorry to 30 say that I do not think that any account of my doings as a student would tend to edification. In fact, I should distinctly warn ingenuous youth to avoid imitating my example. I worked extremely hard when it pleased me, and when it did not-which was a very frequent case- 
I was extremely idle (unless making caricatures of one's pastors and masters is to be called a branch of industry), or else wasted my energies in wrong directions. I read everything I could lay hands upon, including novels, and took up all sorts of pursuits to drop them again quite as 5 speedily. No doubt it was very largely my own fault, but the only instruction from which I ever obtained the proper effect of education was that which I received from $\mathrm{Mr}$. Wharton Jones, who was the lecturer on physiology at the Charing Cross School of Medicine. The extent and pre- ro cision of his knowledge impressed me greatly, and the severe exactness of his method of lecturing was quite to my taste. I do not know that I have ever felt so much respect for anybody as a teacher before or since. I worked hard to obtain his approbation, and he was extremely kind 15 and helpful to the youngster who, I am afraid, took up more of his time than he had any right to do. It was he who suggested the publication of my first scientific paper-a very little one-in the Medical Gazette of 1845 , and most kindly corrected the literary faults which 20 abounded in it, short as it was; for at that time, and for many years afterwards, I detested the trouble of writing, and would take no pains over it.

It was in the early spring of 1846 , that, having finished my obligatory medical studies and passed the first 25 M.D. examination at the London University,-though I was still too young to qualify at the College of Surgeons,-I was talking to a fellow-student (the present eminent physician, Sir Joseph Fayrer), and wondering what I should do to meet the imperative necessity for 30 earning my own bread, when my friend suggested that I should write to Sir William Burnett, at that time DirectorGeneral for the Medical Service of the Navy, for an appointment. I thought this rather a strong thing to do, 
as Sir William was personally unknown to me, but my cheery friend would not listen to my scruples, so I went to my lodgings and wrote the best letter I could devise. A few days afterwards I received the usual official cir5 cular acknowledgment, but at the bottom there was written an instruction to call at Somerset House on such a day. I thought that looked like business, so at the appointed time I called and sent in my card, while I waited in Sir William's ante-room. $\mathrm{He}$ was a tall, Io shrewd-looking old gentleman, with a broad Scotch accent-and I think I see him now as he entered with my card in his hand. The first thing he did was to return it, with the frugal reminder that I should probably find it useful on some other occasion. The second was to ask

I5 whether I was an Irishman. I suppose the air of modesty about my appeal must have struck him. I satisfied the Director-General that I was English to the backbone, and he made some inquiries as to my student career, finally desiring me to hold myself ready for examination. Having

20 passed this, I was in her Majesty's service, and entered on the books of Nelson's old ship, the Victory, for duty at Haslar Hospital, about a couple of months after I made my application.

My official chief at Haslar was a very remarkable per25 son, the late Sir John Richardson, an excellent naturalist, and far-famed as an indomitable Arctic traveler. He was a silent, reserved man, outside the circle of his family and intimates; and, having a full share of youthful vanity, I was extremely disgusted to find that "Old John," as we 30 irreverent youngsters called him, took not the slightest notice of my worshipful self either the first time I attended him, as it was my duty to do, or for some weeks afterwards. I am afraid to think of the lengths to which my tongue may have run on the subject of the churlish- 
ness of the chief, who was, in truth, one of the kindesthearted and most considerate of men. But one day, as I was crossing the hospital square, Sir John stopped me, and heaped coals of fire on my head by telling me that he had tried to get me one of the resident appointments, much 5 coveted by the assistant surgeons, but that the Admiralty had put in another man. "However," said he, "I mean to keep you here till I can get you something you will like," and turned upon his heel without waiting for the thanks I stammered out. That explained how it was I had ro not been packed off to the west coast of Africa like some of my juniors, and why, eventually, I remained altogether seven months at Haslar.

After a long interval, during which "Old John" ignored my existence almost as completely as before, he I5 stopped me again as we met in a casual way, and describing the service on which the Rattlesnake was likely to be employed, said that Captain Owen Stanley, who was to command the ship, had asked him to recommend an assistant surgeon who knew something of science; would I 20 like that? Of course I jumped at the offer. "Very well, I give you leave; go to London at once and see Captain Stanley." I went, saw my future commander, who was very civil to me, and promised to ask that I should be appointed to his ship, as in due time I was. It is a singu- 25 lar thing that, during the few months of my stay at Haslar, I had among my messmates two future DirectorsGeneral of the Medical Service of the Navy (Sir Alexander Armstrong and Sir John Watt-Reid), with the present President of the College of Physicians and my 30 kindest of doctors, Sir Andrew Clark.

Life on board her Majesty's ship in those days was a very different affair from what it is now, and ours was exceptionally rough, as we were often many months 
without receiving letters or seeing any civilized people but ourselves. In exchange, we had the interest of being about the last voyagers, I suppose, to whom it could be possible to meet with people who knew nothing of fire5 arms-as we did on the south coast of New Guinea-and of making acquaintance with a variety of interesting savage and semi-civilized people. But, apart from experience of this kind and the opportunities offered for scientific work, to me, personally, the cruise was extremely valuable. It ro was good for me to live under sharp discipline; to be down on the realities of existence by living on bare necessaries; to find out how extremely well worth living life seemed to be when one woke up from a night's rest on a soft plank, with the sky for canopy and cocoa and I5 weevily biscuit the sole prospect for breakfast; and, more especially, to learn to work for the sake of what I got for myself out of it, even if it all went to the bottom and I along with it. My brother officers were as good fellows as sailors ought to be and generally are, but, naturally, 20 they neither knew nor cared anything about my pursuits, nor understood why I should be so zealous in pursuit of the objects which my friends, the middies, christened "Buffons," after the title conspicuous on a-volume of the Suites à Buffon, which stood on my shelf in the chart25 room.

During the four years of our absence, I sent home communication after communication to the "Linnean Society," with the same result as that obtained by Noah when he sent the raven out of his ark. Tired at last of 30 hearing nothing about them, I determined to do or die, and in $1849 \mathrm{I}$ drew up a more elaborate paper and forwarded it to the Royal Society. This was my dove, if I had only known it. But owing to the movements of the ship, I heard nothing of that either until my return to England 
in the latter end of the year 1850, when I found that it was printed and published, and that a huge packet of separate copies awaited me. When I hear some of my young friends complain of want of sympathy and encouragement, I am inclined to think that my naval life was 5 not the least valuable part of my education.

Three years after my return were occupied by a battle between my scientific friends on the one hand and the Admiralty on the other, as to whether the latter ought, or ought not, to act up to the spirit of a pledge they had ro given to encourage officers who had done scientific work by contributing to the expense of publishing mine. At last the Admirálty, getting tired, I suppose, cut short the discussion by ordering me to join a ship, which thing I declined to do, and as Rastignac, in the Père Goriot, says 15 to Paris, I said to London, "à nous deux." I desired to obtain a professorship of either physiology or comparative anatomy, and as vacancies occurred I applied, but in vain. My friend, Professor Tyndall, and I were candidates at the same time, he for the chair of physics and I for that of 20 natural history in the University of Toronto, which, fortunately, as it turned out, would not look at either of us. I say fortunately, not from any lack of respect for Toronto, but because I soon made up my mind that London was the place for me, and hence I have steadily declined 25 the inducements to leave it, which have at various times been offered. At last, in 1854, on the translation of my warm friend Edward Forbes, to Edinburgh, Sir Henry de la Beche, the Director-General of the Geological Survey, offered me the post Forbes had vacated of Paleontologist 30 and Lecturer on Natural History. I refused the former point-blank, and accepted the latter only provisionally, telling Sir Henry that I did not care for fossils, and that I should give up natural history as soon as I could get a 
physiological post. But I held the office for thirty-one years, and a large part of my work has been paleontological.

At that time I disliked public speaking, and had a firm 5 conviction that I should break down every time I opened my mouth. I believe I had every fault a speaker could have (except talking at random or indulging in rhetoric), when I spoke to the first important audience I ever addressed, on a Friday evening at the Royal Institution, in Io I852. Yet, I must confess to having been guilty, malgré moi, of as much public speaking as most of my contemporaries, and for the last ten years it ceased to be so much of a bugbear to me. I used to pity myself for having to go through this training, but I am now more disposed to I5 compassionate the unfortunate audiences, especially my ever friendly hearers at the Royal Institution, who were the subjects of my oratorical experiments.

The last thing that it would be proper for me to do would be to speak of the work of my life, or to say at 20 the end of the day whether I think I have earned my wages or not. Men are said to be partial judges of themselves. Young men may be, I doubt if old men are. Life seems terribly foreshortened as they look back and the mountain they set themselves to climb in youth turns out to be a 25 mere spur of immeasurably higher ranges when, by failing breath, they reach the top. But if I may speak of the objects I have had more or Tess definitely in view since I began the ascent of my hillock, they are briefly these: To promote the increase of natural knowledge and to for30 ward the application of scientific methods of investigation to all the problems of life to the best of my ability, in the conviction which has grown with my growth and strengthened with my strength, that there is no alleviation for the sufferings of mankind except veracity of thought 


\section{Autobiography}

and of action, and the resolute facing of the world as it is when the garment of make-believe by which pious hands have hidden its uglier features is stripped off.

It is with this intent that I have subordinated any reasonable, or unreasonable, ambition for scientific fame 5 which I may have permitted myself to entertain to other ends; to the popularization of science; to the development and organization of scientific education; to the endless series of battles and skirmishes over evolution; and to untiring opposition to that ecclesiastical spirit, that clerical- Io ism, which in England, as everywhere else, and to whatever denomination it may belong, is the deadly enemy of science.

In striving for the attainment of these objects, I have been but one among many, and I shall be well content to 15 be remembered, or even not remembered, as such. Circumstances, among which I am proud to reckon the devoted kindness of many friends, have led to my occupation of various prominent positions, among which the presidency of the Royal Society is the highest. It would be 20 mock modesty on my part, with these and other scientific honors which have been bestowed upon me, to pretend that I have not succeeded in the career which I have followed, rather because I was driven into it than of my own free will; but I am afraid I should not count even 25 these things as marks of success if $I$ could not hope that I had somewhat helped that movement of opinion which has been called the New Reformation. 


\section{LETTERS *}

\section{( $1852-1892)$}

[To Miss Heathorn. London, November 13, 1852. On learning that the Royal Medal was to be conferred upon him for his paper on the Medusæ.]

Going last week to the Royal Society's library for a 5 book, and like the boy in church "thinkin' o' naughten," when I went in, Weld, the Assistant Secretary, said, "Well, I congratulate you." I confess I did not see at that moment what any mortal man had to congratulate 'me about. I had a deuced bad cold, with rheumatism ro in my head; it was a beastly November day and I was very grumpy, so I inquired in a state of mild surprise what might be the matter. Whereupon I learnt that the Medal had been conferred at the meeting of the Council on the day before. I was very pleased and I thought you would I5 be so too, and I thought moreover that it was a fine lever to help us on, and if I could have sent a letter to you immediately I should have sat down and have written one to you on the spot. As it is I have waited for official confirmation and a convenient season.

20 And, now, shall I be very naughty and make a confession? The thing that a fortnight ago (before I got it) I thought so much of, I give you my word I do not care

* These letters are republished here by permission of D:Appleton and Company. 
a pin for. I am sick of it and ashamed of having thought so much of it, and the congratulations I get give me a sort of internal sardonic grin. I think this has come about partly because I did not get the official confirmation of what I had heard for some days, and with my habit of facing 5 the ill side of things I came to the conclusion that Weld had made a mistake, and I went in thought through the whole enormous mortification of having to explain to those to whom I had mentioned it that it was quite a mistake. I found that all this, when I came to look at it, to was by no means so dreadful as it seemed-quite bearable in short-and then I laughed at myself and have cared nothing about the whole concern ever since. In truth I do not think that $I$ am in the proper sense of the word ambitious. I have an enormous longing after the I5 highest and best in all shapes-a longing which haunts me and is the demon which ever impels me to work, and will let me have no rest unless I am doing his behests. The honors of men I value so far as they are evidences of power, but with the cynical mistrust of their judg- 20 ment and my own worthiness, which always haunts me, I put very little faith in them. Their praise makes me sneer inwardly. God forgive me if I do them any great wrong.

I feel and know that all the rewards and honors in the 25 world will ever be worthless for me as soon as they are obtained. I know that always, as now, they will make me more sad than joyful. I know that nothing that could be done would give me the pure and heartfelt joy and peace of mind that your love has given me, and, 30 please God, shall give for many a long year to come, and yet my demon says work! work! you shall not even love unless you work.

Not blinded by any vanity, then; I hope, but viewing 
this stroke of fortune as respects its public estimation only, I think I must look upon the award of this medal as the turning point of my life, as the finger-post teaching me as clearly as anything can what is the true career that 5 lies open before me. For whatever may be my own private estimation of it, there can be no doubt as to the general feeling about this thing, and in case of my candidature for any office it would have the very greatest weight. As you will have seen by my last letter, it only rostrengthens and confirms the conclusion I had come to. Bid me God-speed then-it is all I want to labor cheerfully.

[To Miss Heathorn. London, November 28, 1852. On the funeral of the Duke of Wellington.]

15 You will hear all the details of the Great Duke's state funeral from the papers much better than I can tell you them. I went to the Cathedral (St. Paul's) and had the good fortune to get a capital seat-in front, close to the great door by which every one entered. It was bitter 20 cold, a keen November wind blowing right in, and as I was there from eight till three, I expected nothing less than rheumatic fever the next day; however, I didn't get it. It was pitiful to see the poor old Marquis of Anglesey-a year older than the Duke-standing with 25 bare head in the keen wind close to me for more than three quarters of an hour. It was impressive enoughthe great interior lighted up by a single line of light running along the whole circuit of the cornice, and another encircling the dome, and casting a curious illumina30 tion over the masses of uniforms which filled the great space. The best of our people were there and passed close to me, but the only face that made any great impression 
upon my memory was that of Sir Charles Napier, the conqueror of Scinde. Fancy a very large, broad-winged, and fierce-looking hawk in uniform. Such an eye!

When the coffin and the mourners had passed I closed up with the soldiers and went up under the dome, where 5 I heard the magnificent service in full perfection.

All of it, however, was but stage trickery compared with the noble simplicity of the old man's life. How the old stoic, used to his iron bed and hard hair pillow, would have smiled at all the pomp-submitting to that, how- Io ever, and all other things necessary to the "carrying on of the Queen's Goternment."

I send Tennyson's ode by way of packing-it is not worth much more, the only decent passages to my mind being those I have marked.

The day after to-morrow I go to have my medal presented and to dine and make a speech.

[To Miss Heathorn. London, July 6, 1853. On his new aims and purposes.]

I know that these three years have inconceivably altered 20 me-that from being an idle man, only too happy to flow into the humors of the moment, I have become almost unable to exist without active intellectual excitement. I know that in this I find peace and rest such as $I$ can attain in no other way. From being a mere untried 25 fledgling, doubtful whether the wish to fly proceeded from mere presumption or from budding wings, I have now some confidence in well-tried pinions, which have given me rank among the strongest and foremost. I have always felt how difficult it was for you to realize all 30 this-how strange it must be to you that though your image remained as bright as ever, new interests and pur- 
poses had ranged themselves around it, and though they could claim no preëminence, yet demanded their share of my thoughts. I make no apology for this-it is man's nature and the necessary influence of circumstances which 5 will so have it; and depend, however painful our present separation may be, the spectacle of a man who had given up the cherished purpose of his life, the Esau who had sold his birthright for a mess of pottage and with it his self-respect, would, before- long years were over our Io heads, be infinitely more painful. Depend upon it, the trust which you placed in my hands when I left you-to choose for both of us-has not been abused. Hemmed in by all sorts of difficulties, my choice was a narrow one, and I was guided more by circumstances than my own free 15 will. Nevertheless the path has shown itself to be a fair one, neither more difficult nor less so than most paths in life in which a man of energy may hope to do much if he believes in himself, and is at peace within.

My course in life is taken. I will not leave London20 I will make myself a name and position as well as an income by some kind of pursuit connected with science, which is the thing for which nature has fitted me if she has ever fitted any one for anything. Bethink yourself whether you can cast aside all repining and doubt, and 25 devote yourself in patience and trust to helping me along my path as no one else could. I know what I ask, and the sacrifice I demand, and if this were the time to use false modesty, I should say how little I have to offer in return.

30 I am full of faults, but I am real and true, and the whole devotion of an earnest soul cannot be overprized.

It is as if all that old life at Holmwood had merely been a preparation for the real life of our love-as if we were then children ignorant of life's real purpose-as if 
these last months had merely been my old doubts over again, whether I had rightly or wrongly interpreted the manner and the words that had given me hope.

We will begin the new love of woman and man, no longer that of boy and girl, conscious that we have aims 5 and purposes as well as affections, and that, if love is sweet, life is dreadfully stern and earnest.

[To Charles Darwin. London, November 23, 1859. On The Origin of Species.]

My dear Darwin-I finished your book yesterday, 10 a lucky examination having furnished me with a few hours of continuous leisure.

Since I read Von Bär's essays, nine years ago, no work on Natural History Science I have met with has made so great an impression upon me, and I do most heartily thank 15 you for the great store of new views you have given me. Nothing, I think, can be better than the tone of the book; it impresses those who know about the subject. As for your doctrine, I am prepared to go to the stake, if requisite, in support of Chapter IX and most parts of 20 Chapters X, XI, XII; and Chapter XIII contains much that is most admirable, but on one or two points $I$ enter a caveat until I can see further into all sides of the question.

As to the first four chapters, I agree thoroughly and fully with all the principles laid down in them. I think 25 you have demonstrated a true cause for the production of species, and have thrown the onus probandi, that species did not arise in the way you suppose, on your adversaries.

But I feel that I have not yet by any means fully realized the bearings of those most remarkable and original 30 Chapters-III, IV, and V; and I will write no more about them just now. 
The only objections that have occurred to me are-Ist, That you have loaded yourself with an unnecessary difficulty in adopting Natura non facit saltum so unreservedly; and 2 d, It is not clear to me why, if continual physical 5 conditions are of so little moment as you suppose, variation should occur at all.

However, I must read the book two or three times more before I presume to begin picking holes.

I trust you will not allow yourself to be in any way Io disgusted or annoyed by the considerable abuse and misrepresentation which, unless I greatly mistake, is in store for you. Depend upon it, you have earned the lasting gratitude of all thoughtful men. And as to the curs which will bark and yelp, you must recollect that some of I5 your friends, at any rate, are endowed with an amount of combativeness which (though you have often and justly rebuked it) may stand you in good stead.

I am sharpening up my claws and beak in readiness.

Looking back over my letter, it really expresses so 20 feebly all I think about you and your noble book, that I am half-ashamed of it; but you will understand that, like the parrot in the story, "I think the more."-Ever yours faithfully,

T. H. HUXLEY.

[To John Tyndall. Naples, March 31, 1872. On 25 Mount Vesuvius.]

From Messina I came on here, and had the great good fortune to find Vesuvius in eruption. Before this fact the vision of good Bence Jones forbidding much exertion vanished into thin air, and on Thursday up I went in 30 company with Ray Lankester and my friend Dohrn's father, Dohrn himself being unluckily away. We had a glorious day, and did not descend till late at night. The 
great crater was not very active, and contented itself with throwing out great clouds of steam and volleys of red-hot stones now and then. These were thrown towards the south-west side of the cone, so that it was practicable to walk all round the northern and eastern 5 lip, and look down into the Hell Gate. I wished you were there to enjoy the sight as much as I did. No lava was issuing from the great crater, but on the north side of this, a little way below the top, an independent cone had established itself as the most charming little pocket- Io volcano imaginable. It could not have been more than 100 feet high, and at the top was a crater not more than six or seven feet across. Out of this, with a noise exactly resembling a blast furnace and a slowly-working high pressure steam engine combined, issued a violent torrent 15 of steam and fragments of semi-fluid lava as big as one's fist, and sometimes bigger. These shot up sometimes as much as 100 feet, and then fell down on the sides of the little crater, which could be approached within fifty feet without any danger. As darkness set in, the spectacle was 20 most strange. The fiery stream found a lurid reflection in the slowly drifting steam cloud, which overhung it, while the red-hot stones which shot through the cloud shone strangely beside the quiet stars in a moonless sky.

Not from the top of this cinder cone, but from its 25 side, a couple of hundred feet down, a stream of lava issued. At first it was not more than a couple of feet wide, but whether from receiving accessions or merely from the different form of slope, it got wider on its journey down to the Atrio del Cavallo, a thousand feet below. 30 The slope immediately below the exit must have been near fifty, but the lava did not flow quicker than very thick treacle would do under like circumstances. And there were plenty of freshly cooled lava streams about, in- 
clined at angles far greater than those which that learned Academician, Elie de Beaumont, declared to be possible. Naturally I was ashamed of these impertinent lava currents, and felt inclined to call them "Laves mous 5 seuses."

Courage, my friend, behold land! I know you love my handwriting. I am off to Rome to-day, and this dayweek, if all goes well, I shall be under my own roof-tree again. In fact I hope to reach London on Saturday evenso ing. It will be jolly to see your face again.-Ever yours faithfully,

T. H. HuXley.

[To the Lord Mayor of London. Monte Generoso, Switzerland, June 25, I889. On Louis Pasteur.]

My Lord Mayor-I greatly regret my inability to be I5 present at the meeting which is to be held, under your Lordship's auspices, in reference to M. Pasteur and his Institute. The unremitting labors of that eminent Frenchman during the last half-century have yielded rich harvests of new truths, and are models of exact and refined 20 research. As such they deserve, and have received, all the honors which those who are the best judges of their purely scientific merits are able to bestow. But it so happens that these subtle and patient searchings out of the ways of the infinitely little- of the swarming life 25 where the creature that measures one-thousandth part of an inch is a giant-have also yielded results of supreme practical importance. The path of M. Pasteur's investigations is strewed with gifts of vast monetary value to the silk trades, the brewer, and the wine mer30 chant. And this being so, it might well be a proper and graceful act on the part of the representatives of trade and commerce in its greatest center to make some public 
recognition of M. Pasteur's services, even if there were nothing further to be said about them.

But there is much more to be said. M. Pasteur's direct and indirect contributions to our knowledge of the causes of diseased states, and of the means of preventing their $\mathbf{5}$ recurrence, are not measurable by money values, but by those of healthy life and diminished suffering to men. Medicine, surgery, and hygiene have all been powerfully affected by M. Pasteur's work, which has culminated in his method of treating hydrophobia. I cannot con- Io ceive that any competently instructed person can consider M. Pasteur's labors in this direction without arriving at the conclusion that, if any man has earned the praise and honor of his fellows, he has. I find it no less difficult to imagine that our wealthy country should be other 15 than ashamed to continue to allow its citizens to profit by the treatment freely given at the Institute without contributing to its support. Opposition to the proposals which your Lordship sanctions would be equally inconceivable if it arose out of nothing but the facts of the 20 case thus presented. But the opposition which, as I see from the English papers, is threatened has really for the most part nothing to do either with $M$. Pasteur's merits or with the efficacy of his method of treating hydrophobia. It proceeds partly from the fanatics of laissez faire, who 25 think it better to rot and die than to be kept whole and lively by State interference, partly from the blind opponents of properly conducted physiological experimentation, who prefer that men should suffer than rabbits or dogs, and partly from those who for other but not less power- 30 ful motives hate everything which contributes to prove the value of strictly scientific methods of inquiry in all those questions which affect the welfare of society.

I sincerely trust that the good sense of the meeting over 
which your Lordship will preside will preserve it from being influenced by those unworthy antagonisms, and that the just and benevolent enterprise you have undertaken may have a happy issue.-I am, my Lord Mayor, your 5 obedient servant,

Thomas H. HuXley.

[To John Tyndall. Hodeslea, Eastbourne, October I5, 1892. On the funeral of Alfred Tennyson.]

My dear Tyndall-I think you will like to hear that the funeral yesterday lacked nothing to make it worthy ro of the dead or the living.

Bright sunshine streamed through the windows of the nave, while the choir was in half gloom, and as each shaft of light illuminated the flower-covered bier as it slowly traveled on, one thought of the bright succession of his 15 works between the darkness before and the darkness after. I am glad to say that the Royal Society was represented by four of its chief officers, and nine of the commonalty, including myself. Tennyson has a right to that, as the first poet since Lucretius who has understood the 20 drift of science.

We have heard nothing of you and your wife for ages. Ask her to give us news, good news, I hope, of both.

My wife is better than she was, and joins with me in 25love.-Ever yours affectionately,

T. H. HuXLEY.

[To a young man. Hodeslea, Eastbourne, November 5, I892. On choosing a profession.]

Dear Sir-I am very sorry that the pressure of other occupations has prevented me from sending an earlier 30 reply to your letter. 
In my opinion a man's first duty is to find a way of supporting himself, thereby relieving other people of the necessity of supporting him. Moreover, the learning to do work of practical value in the world, in an exact and careful manner, is of itself a very important education, the 5 effects of which make themselves felt in all other pursuits. The habit of doing that which you do not care about when you would much rather be doing something else, is invaluable. It would have saved me a frightful waste of time if I had ever had it drilled into me in youth. Io

Success in any scientific career requires an unusual equipment of capacity, industry, and energy. If you possess that equipment you will find leisure enough after your daily commercial work is over, to make an opening in the scientific ranks for yourself. If you do not, you 15 had better stick to commerce. Nothing is less to be desired than the fate of a young man, who, as the Scotch proverb says, in "trying to make a spoon spoils a horn," and becomes a mere hanger-on in literature or in science, when he might have been a useful and a valuable member 20 of Society in other occupations.

I think that your father ought to see this letter.Yours faithfully,

T. H. HuXley. 


\section{ON THE ADVISABLENESS OF IMPROVING NATURAL KNOWLEDGE}

\section{(1866)}

THIs time two hundred years ago-in the beginning of January, 1666-those of our forefathers who inhabited this great and ancient city, took breath between the shocks of two fearful calamities: one not quite past, although its 5 fury had abated; the other to come.

Within a few yards of the very spot on which we are assembled, so the tradition runs, that painful and deadly malady, the plague, appeared in the latter months of 1664; and, though no new visitor, smote the people of ro England, and especially of her capital, with a violence unknown before, in the course of the following year. The hand of a master has pictured what happened in those dismal months; and in that truest of fictions, The History of the Plague Year, Defoe shows death, with I5 every accompaniment of pain and terror, stalking through the narrow streets of old London, and changing their busy hum into a silence broken only by the wailing of the mourners of fifty thousand dead; by the woful denunciations and mad prayers of fanatics; and by the madder 20 yells of despairing profligates.

But, about this time in 1666 , the death-rate had sunk to nearly its ordinary amount; a case of plague occurred only here and there, and the richer citizens who had flown from the pest had returned to their dwellings. The 25 remnant of the people began to toil at the accustomed round 
of duty, or of pleasure; and the stream of city life bid fair to flow back along its old bed, with renewed and uninterrupted vigor.

The newly kindled hope was deceitful. The great plague, indeed, returned no more; but what it had done 5 for the Londoners, the great fire, which broke out in the autumn of 1666, did for London; and, in September of that year, a heap of ashes and the indestructible energy of the people were all that remained of the glory of fivesixths of the city within the walls.

Our forefathers had their own ways of accounting for each of these calamities. They submitted to the plague in humility and in penitence, for they believed it to be the judgment of God. But, towards the fire they were furiously indignant, interpreting it as the effect of the 15 malice of man,-as the work of the Republicans, or of the Papists, according as their prepossessions ran in favor of loyalty or of Puritanism.

It would, I fancy, have fared but ill with one who, standing where I now stand, in what was then a thickly 20 peopled and fashionable part of London, should have broached to our ancestors the doctrine which I now propound to you-that all their hypotheses were alike wrong; that the plague was no more, in their sense, Divine judgment, than the fire was the work of any political, or of 25 any religious, sect; but that they were themselves the authors of both plague and fire, and that they must look to themselves to prevent the recurrence of calamities, to all appearance so peculiarly beyond the reach of human control-so evidently the result of the wrath of God, or of 30 the craft and subtlety of an enemy.

And one may picture to oneself how harmoniously the holy cursing of the Puritan of that day would have chimed 
in with the unholy cursing and the crackling wit of the Rochesters and Sedleys, and with the revilings of the political fanatics, if my imaginary plain dealer had gone on to say that, if the return of such misfortunes were ever 5 rendered impossible, it would not be in virtue of the victory of the faith of Laud, or of that of Milton; and, as little, by the triumph of republicanism, as by that of monarchy. But that the one thing needful for compassing this end was, that the people of England should Io second the efforts of an insignificant corporation, the establishment of which, a few years before the epoch of the great plague and the great fire, had been as little noticed, as they were conspicuous.

Some twenty years before the outbreak of the plague I5 a few calm and thoughtful students banded themselves together for the purpose, as they phrased it, of "improving natural knowledge." The ends they proposed to attain cannot be stated more clearly than in the words of one of the founders of the organization:-

20 "Our business was (precluding matters of theology and state affairs) to discourse and consider of philosophical inquiries, and such as related thereunto:-as Physick, Anatomy, Geometry, Astronomy, Navigation, Staticks, Magneticks, Chymicks, Mechanicks, and Natural Ex25 periments; with the state of these studies and their cultivation at home and abroad. We then discoursed of the circulation of the blood, the valves in the veins, the venæ lacteæ, the lymphatic vessels, the Copernican hypothesis, the nature of comets and new stars, the satellites of Jupi30 ter, the oval shape (as it then appeared) of Saturn, the spots on the sun and its turning on its own axis, the inequalities and selenography of the moon, the several phases of Venus and Mercury, the improvement of telescopes 
and grinding of glasses for that purpose, the weight of air, the possibility or impossibility of vacuities and nature's abhorrence thereof, the Torricellian experiment in quicksilver, the descent of heavy bodies and the degree of acceleration therein, with divers other things of like na- 5 ture, some of which were then but new discoveries, and others not so generally known and embraced as now they are; with other things appertaining to what hath been called the 'New Philosophy,' which, from the times of Galileo at Florence, and Sir Francis Bacon (Lord ro Verulam) in England, hath been much cultivated in Italy, France, Germany, and other parts abroad, as well as with us in England."

The learned Dr. Wallis, writing in 1696, narrates, in these words, what happened half a century before, or 15 about 1645. The associates met at Oxford, in the rooms of Dr. Wilkins, who was destined to become a bishop; and subsequently coming together in London, they attracted the notice of the king. And it is a strange evidence of the taste for knowledge which the most obviously worth- 20 less of the Stuarts shared with his father and grandfather, that Charles the Second was not content with saying witty things about his philosophers, but did wise things with regard to them. For he not only bestowed upon them such attention as he could spare from his poodles 25 and his mistresses, but, being in his usual state of impecuniosity, begged for them of the Duke of Ormond; and, that step being without effect, gave them Chelsea College, a charter, and a mace: crowning his favors in the best way they could be crowned, by burdening 30 them no further with royal patronage or state interference.

Thus it was that the half-dozen young men, studious of the "New Philosophy," who met in one another's lodgings in Oxford or in London, in the middle of the seven- 
teenth century, grew in numerical and in real strength, until, in its latter part, the "Royal Society for the Improvement of Natural Knowledge" had already become famous, and had acquired a claim upon the veneration of 5 Englishmen, which it has ever since retained, as the principal focus of scientific activity in our islands, and the chief champion of the cause it was formed to support.

It was by the aid of the Royal Society that Newton published his Principia. If all the books in the world, Io except the Philosophical Transactions, were destroyed, it is safe to say that the foundations of physical science would remain unshaken, and that the vast intellectual progress of the last two centuries would be largely, though incompletely, recorded. Nor have any signs of halting I5 or of decrepitude manifested themselves in our own times. As in Dr. Wallis' days, so in these, "our business is, precluding theology and state affairs, to discourse and consider of philosophical inquiries." But our "Mathematick" is one which Newton would have to go to school to 20 learn; our "Staticks, Mechanicks, Magneticks, Chymicks, and Natural Experiments" constitute a mass of physical and chemical knowledge, a glimpse at which would compensate Galileo for the doings of a score of inquisitorial cardinals; our "Physick" and "Anatomy" have embraced 25 such infinite varieties of being, have laid open such new worlds in time and space, have grappled, not unsuccessfully, with such complex problems, that the eyes of Vesalius and of Harvey might be dazzled by the sight of the tree that has grown out of their grain of mustard seed.

30 The fact is perhaps rather too much, than too little, forced upon one's notice, nowadays, that all this marvelous intellectual growth has a no less wonderful expression in practical life; and that, in this respect, if in no other, the movement symbolized by the progress 


\section{Improving Natural Knowledge}

of the Royal Society stands without a parallel in the history of mankind.

A series of volumes as bulky as the Transactions of the Royal Society might possibly be filled with the subtle speculations of the Schoolmen; not improbably, the ob- 5 taining a mastery over the products of medieval thought might necessitate an even greater expenditure of time and of energy than the acquirement of the "New Philosophy;" but though such work engrossed the best intellects of Europe for a longer time than has elapsed since the great to fire, its effects were "writ in water," so far as our social state is concerned.

On the other hand, if the noble first President of the Royal Society could revisit the upper air and once more gladden his eyes with a sight of the familiar mace, he 15 would find himself in the midst of a material civilization more different from that of his day, than that of the seventeenth, was from that of the first, century. And if Lord Brouncker's native sagacity had not deserted his ghost, he would need no long reflection to discover that 20 all these great ships, these railways, these telegraphs, these factories, these printing-presses, without which the whole fabric of modern English society would collapse into a mass of stagnant and starving pauperism, - that all these pillars of our State are but the ripples and the bub- 25 bles upon the surface of that great spiritual stream, the springs of which, only he and his fellows were privileged to see; and seeing, to recognize as that which it behooved them above all things to keep pure and undefiled.

It may not be too great a flight of imagination to 30 conceive our noble revenant not forgetful of the great troubles of his own day, and anxious to know how often London had been burned down since his time, and how often the plague had carried off its thousands. He would 


\section{4 \\ Selections from Huxley}

have to learn that, although London contains tenfold the inflammable matter that it did in 1666; though, not content with filling our rooms with woodwork and light draperies, we must needs lead inflammable and explosive 5 gases into every corner of our streets and houses, we never allow even a street to burn down. And if he asked how this had come about, we should have to explain that the improvement of natural knowledge has furnished us with dozens of machines for throwing water upon fires, any Io one of which would have furnished the ingenious Mr. Hooke, the first "curator and experimenter" of the Royal Society, with ample materials for discourse before half a dozen meetings of that body; and that, to say truth, except for the progress of natural knowledge, we should I5 not have been able to make even the tools by which these machines are constructed. And, further, it would be necessary to add, that although severe fires sometimes occur and inflict great damage, the loss is very generally compensated by societies, the operations of which have 20 been rendered possible only by the progress of natural knowledge in the direction of mathematics, and the accumulation of wealth in virtue of other natural knowledge.

But the plague? My Lord Brouncker's observation 25 would not, I fear, lead him to think that Englishmen of the nineteenth century are purer in life, or more fervent in religious faith, than the generation which could produce a Boyle, an Evelyn, and a Milton. He might find the mud of society at the bottom, instead of at the top, 3obut I fear that the sum total would be as deserving of swift judgment as at the time of the Restoration. And it would be our duty to explain once more, and this time not without shame, that we have no reason to believe that it is the improvement of our faith, nor that of our 


\section{Improving Natural Knowledge}

morals, which keeps the plague from our city; but, again, that it is the improvement of our natural knowledge.

We have learned that pestilences will only take up their abode among those who have prepared unswept and ungarnished residences for them. Their cities must have $\mathbf{5}$ narrow, unwatered streets, foul with accumulated garbage. Their houses must be ill-drained, ill-lighted, ill-ventilated. Their subjects must be ill-washed, ill-fed, ill-clothed. The. London of 1665 was such a city. The cities of the East, where plague has an enduring dwelling, are such cities. ro We, in later times, have learned somewhat of Nature, and partly obey her. Because of this partial improvement of our natural knowledge and of that fractional obedience, we have no plague; because that knowledge is still very imperfect and that obedience yet incomplete, I5 typhus is our companion and cholera our visitor. But it is not presumptuous to express the belief that, when our knowledge is more complete and our obedience the expression of our knowledge, London will count her centuries of freedom from typhus and cholera, as she now gratefully 20 reckons her two hundred years of ignorance of that plague which swooped upon her thrice in the first half of the seventeenth century.

Surely, there is nothing in these explanations which is not fully borne out by the facts? Surely, the principles 25 involved in them are now admitted among the fixed beliefs of all thinking men? Surely, it is true that our countrymen are less subject to fire, famine, pestilence, and all the evils which result from a want of command over and due anticipation of the course of Nature, than were 30 the countrymen of Milton; and health, wealth, and wellbeing are more abundant with us than with them? But no less certainly is the difference due to the improvement of our knowledge of Nature, and the extent to which 
that improved knowledge has been incorporated with the household words of men, and has supplied the springs of their daily actions.

Granting for a moment, then, the truth of that which 5 the depreciators of natural knowledge are so fond of urging, that its improvement can only add to the resources of our material civilization; admitting it to be possible that the founders of the Royal Society themselves looked for no other reward than this, I cannot confess that I was 1o guilty of exaggeration when I hinted, that to him who had the gift of distinguishing between prominent events and important events, the origin of a combined effort on the part of mankind to improve natural knowledge might have loomed larger than the Plague and have outI5 shone the glare of the Fire; as a something fraught with a wealth of beneficence to mankind, in comparison with which the damage done by those ghastly evils would shrink into insignificance.

It is very certain that for every victim slain by the 20 plague, hundreds of mankind exist and find a fair share of happiness in the world, by the aid of the spinning jenny. And the great fire, at its worst, could not have burned the supply of coal, the daily working of which, in the bowels of the earth, made possible by the steam pump, 25 gives rise to an amount of wealth to which the millions lost in old London are but as an old song.

But spinning jenny and steam pump are, after all, but toys, possessing an accidental value; and natural knowledge creates multitudes of more subtle contrivances, the 30 praises of which do not happen to be sung because they are not directly convertible into instruments for creating wealth. When I contemplate natural knowledge squandering such gifts among men, the only appropriate com- 
parison I can find for her is, to liken her to such a peasant woman as one sees in the Alps, striding ever upward, heavily burdened, and with mind bent only on her home; but yet, without effort and without thought, knitting for her children. Now stockings are good and comfortable 5 things, and the children will undoubtedly be much the better for them; but surely it would be short-sighted, to say the least of it, to depreciate this toiling mother as a mere stocking-machine-a mere provider of physical comforts?

However, there are blind leaders of the blind, and not a few of them, who take this view of natural knowledge, and can see nothing in the bountiful mother of humanity but a sort of comfort-grinding machine. According to them, the improvement of natural knowledge always has 15 been, and always must be, synonymous with no more than the improvement of the material resources and the increase of the gratifications of men.

Natural knowledge is, in their eyes, no real mother of mankind, bringing them up with kindness, and, if need 20 be, with sternness, in the way they should go, and instructing them in all things needful for their welfare; but a sort of fairy godmother, ready to furnish her pets with shoes of swiftness, swords of sharpness, and omnipotent Aladdin's lamps, so that they may have telegraphs to 25 Saturn, and see the other side of the moon, and thank God they are better than their benighted ancestors.

If this talk were true, I, for one, should not greatly care to toil in the service of natural knowledge. I think I would just as soon be quietly chipping my own flint 30 ax, after the manner of my forefathers a few thousand years back, as be troubled with the endless malady of thought which now infests us all, for such reward. But I venture to say that such views are contrary alike to 
reason and to fact. Those who discourse in such fashion seem to me to be so intent upon trying to see what is above Nature, or what is behind her, that they are blind to what stares them in the face, in her.

5 I should not venture to speak thus strongly if my justification were not to be found in the simplest and most obvious facts, -if it needed more than an appeal to the most notorious truths to justify my assertion, that the improvement of natural knowledge, whatever direcIo tion it has taken, and however low the aims of those who may have commenced it-has not only conferred practical benefits on men, but, in so doing, has effected a revolution in their conceptions of the universe and of themselves, and has profoundly altered their modes of I5 thinking and their views of right and wrong. I say that natural knowledge, seeking to satisfy natural wants, has found the ideas which can alone still spiritual cravings. I say that natural knowledge, in desiring to ascertain the laws of comfort, has been driven to discover those 20 of conduct, and to lay the foundations of a new morality.

Let us take these points separately; and, first, what great ideas has natural knowledge introduced into men's minds?

I cannot but think that the foundations of all natural 25 knowledge were laid when the reason of man first came face to face with the facts of Nature: when the savage first learned that the fingers of one hand are fewer than those of both; that it is shorter to cross a stream than to head it; that a stone stops where it is unless it be 30 moved, and that it drops from the hand which lets it go; that light and heat come and go with the sun; that sticks burn away in fire; that plants and animals grow and die; that if he struck his fellow-savage a blow he would 
make him angry, and perhaps get a blow in return, while if he offered him a fruit he would please him, and perhaps receive a fish in exchange. When men had acquired this much knowledge, the outlines, rude though they were, of mathematics, of physics, of chemistry, of biology, 5 of moral, economical, and political science, were sketched. Nor did the germ of religion fail when science began to bud. Listen to words which, though new, are yet three thousand years old:-

".. When in heaven the stars about the moon

Look beautiful, when all the winds are laid, And every height comes out, and jutting peak And valley, and the immeasurable heavens Break open to their highest, and all the stars Shine, and the shepherd gladdens in his heart." *

If the half-savage Greek could share our feelings thus far, it is irrational to doubt that he went further, to find, as we do, that upon that brief gladness there follows a certain sorrow,- - the little light of awakened human intelligence shines so mere a spark amidst the abyss of the 20 unknown and unknowable; seems so insufficient to do more than illuminate the imperfections that cannot be remedied, the aspirations that cannot be realized, of man's own nature. But in this sadness, this consciousness of the limitation of man, this sense of an open secret 25 which he cannot penetrate, lies the essence of all religion; and the attempt to embody it in the forms furnished by the intellect is the origin of the higher theologies.

Thus it seems impossible to imagine but that the foundations of all knowledge-secular or sacred-were laid when 30 intelligence dawned, though the superstructure remained

* Need it be said that this is Tennyson's English for Homer's Greek? 
for long ages so slight and feeble as to be compatible with the existence of almost any general view respecting the mode of governance of the universe. No doubt, from the first, there were certain phenomena which, to 5 the rudest mind, presented a constancy of occurrence, and suggested that a fixed order ruled, at any rate, among them. I doubt if the grossest of Fetish worshipers ever imagined that a stone must have a god within it to make it fall, or that a fruit had a god within it to make it Io taste sweet. With regard to such matters as these, it is hardly questionable that mankind from the first took strictly positive and scientific views.

But, with respect to all the less familiar occurrences which present themselves, uncultured man, no doubt, has 15 always taken himself as the standard of comparison, as the center and measure of the world; nor could he well avoid doing so. And finding that his apparently uncaused will has a powerful effect in giving rise to many occurrences, he naturally enough ascribed other and greater 20 events to other and greater volitions, and came to look upon the world and all that therein is, as the product of the volitions of persons like himself, but stronger, and capable of being appeased or angered, as he himself might be soothed or irritated. Through such conceptions of the 25 plan and working of the universe all mankind have passed, or are passing. And we may now consider, what has been the effect of the improvement of natural knowledge on the views of men who have reached this stage, and who have begun to cultivate atural knowledge with no desire 30 but that of "increasing God's honor and bettering man's estate."

For example: what could seem wiser, from a mere material point of view, more innocent, from a theological one, to an ancient people, than that they should learn 
the exact succession of the seasons, as warnings for their husbandmen; or the position of the stars, as guides to their rude navigators? But what has grown out of this search for natural knowledge of so merely useful a character? You all know the reply. Astronomy,-which 5 of all sciences has filled men's minds with general ideas of a character most foreign to their daily experience, and has, more than any other, rendered it impossible for them to accept the beliefs of their fathers. Astronomy,which tells them that this so vast and seemingly solid earth to is but an atom among atoms, whirling, no man knows whither, through illimitable space; which demonstrates that what we call the peaceful heaven above us, is but that space, filled by an infinitely subtle matter whose particles are seething and surging, like the waves of an angry sea; 15 which opens up to us infinite regions where nothing is known, or ever seems to have been known, but matter and force, operating according to rigid rules; which leads us to contemplate phenomena the very nature of which demonstrates that they must have had a beginning, and that they 20 must have an end, but the very nature of which also proves that the beginning was, to our conceptions of time, infinitely remote, and that the end is as immeasurably distant.

But it is not alone those who pursue astronomy who 25 ask for bread and receive ideas. What more harmless than the attempt to lift and distribute water by pumping it; what more absolutely and grossly utilitarian? But out of pumps grew the discussions about Nature's abhorrence of a vacuum; and then it was discovered that 30 Nature does not abhor a vacuum, but that air has weight; and that notion paved the way for the doctrine that all matter has weight, and that the force which produces weight is co-extensive with the universe,-in short, to 
the theory of universal gravitation and endless force. While learning how to handle gases led to the discovery of oxygen, and to modern chemistry, and to the notion of the indestructibility of matter.

5 Again, what simpler, or more absolutely practical, than the attempt to keep the axle of a wheel from heating when the wheel turns round very fast? How useful for carters and gig drivers to know something about this; and how good were it, if any ingenious person would Io find out the cause of such phenomena, and thence educe a general remedy for them. Such an ingenious person was Count Rumford; and he and his successors have landed us in the theory of the persistence, or indestructibility, of force. And in the infinitely minute, as in the infinitely 15 great, the seekers after natural knowledge, of the kinds called physical and chemical, have everywhere found a definite order and succession of events which seem never to be infringed.

And how has it fared with "Physick" and Anatomy? 20 Have the anatomist, the physiologist, or the physician, whose business it has been to devote themselves assiduously to that eminently practical and direct end, the alleviation of the sufferings of mankind,- -have they been able to confine their vision more absolutely to the strictly use25 ful? I fear they are worst offenders of all. For if the astronomer has set before us the infinite magnitude of space, and the practical eternity of the duration of the universe; if the physical and chemical philosophers have demonstrated the infinite minuteness of its constituent 3oparts, and the practical eternity of matter and of force; and if both have alike proclaimed the universality of a definite and predicable order and succession of events, the workers in biology have not only accepted all these, but have added more startling theses of their own. For, as 


\section{Improving Natural Knowledge}

the astronomers discover in the earth no center of the universe, but an eccentric speck, so the naturalists find man to be no center of the living world, but one amidst endless modifications of life; and as the astronomer observes the mark of practically endless time set upon the arrange- 5 ments of the solar system so the student of life finds the records of ancient forms of existence peopling the world for ages, which, in relation to human experience, are infinite.

Furthermore, the physiologist finds life to be as de- 1o pendent for its manifestation on particular molecular arrangements as any physical or chemical phenomenon; and, wherever he extends his researches, fixed order and unchanging causation reveal themselves, as plainly as in the rest of Nature.

Nor can I find that any other fate has awaited the germ of Religion. Arising, like all other kinds of knowledge, out of the action and interaction of man's mind, with that which is not man's mind, it has taken the intellectual coverings of Fetishism or Polytheism; of Theism 20 or Atheism; of Superstition or Rationalism. With these, and their relative merits and demerits, I have nothing to do; but this it is needful for my purpose to say, that if the religion of the present differs from that of the past, it is because the theology of the present has become more 25 scientific than that of the past; because it has not only renounced idols of wood and idols of stone, but begins to see the necessity of breaking in pieces the idols built up of books and traditions and fine-spun ecclesiastical cobwebs: and of cherishing the noblest and most human of 30 man's emotions, by worship "for the most part of the silent sort" at the altar of the Unknown and Unknowable.

Such are a few of the new conceptions implanted in 
our minds by the improvement of natural knowledge. Men have acquired the ideas of the practically infinite extent of the universe and of its practical eternity; they are familiar with the conception that our earth is but an 5 infinitesimal fragment of that part of the universe which can be seen; and that, nevertheless, its duration is, as compared with our standards of time, infinite. They have further acquired the idea that man is but one of innumerable forms of life now existing in the globe, and that Io the present existences are but the last of an immeasurable series of predecessors. Moreover, every step they have made in natural knowledge has tended to extend and rivet in their minds the conception of a definite order of the universe-which is embodied in what are called, by an I5 unhappy metaphor, the laws of Nature-and to narrow the range and loosen the force of men's belief in spontaneity, or in changes other than such as arise out of that definite order itself.

Whether these ideas are well or ill founded is not the 20 question. No one can deny that they exist, and have been the inevitable outgrowth of the improvement of natural knowledge. And if so, it cannot be doubted that they are changing the form of men's most cherished and most important convictions.

25 And as regards the second point-the extent to which the improvement of natural knowledge has remodeled and altered what may be termed the intellectual ethics of men,-what are among the moral convictions most fondly held by barbarous and semi-barbarous people?

30 They are the convictions that authority is the soundest basis of belief; that merit attaches to a readiness to believe; that the doubting disposition is a bad one, and skepticism a sin; that when good authority has pro- 


\section{Improving Natural Knowledge}

nounced what is to be believed, and faith has accepted it, reason has no further duty. There are many excellent persons who yet hold by these principles, and it is not my present business, or intention, to discuss their views. All I wish to bring clearly before your minds is the unques- 5 tionable fact, that the improvement of natural knowledge is effected by methods which directly give the lie to all these convictions, and assume the exact reverse of each to be true.

The improver of natural knowledge absolutely refuses so to acknowledge authority, as such. For him, skepticism is the highest of duties; blind faith the one unpardonable sin. And it cannot be otherwise, for every great advance in natural knowledge has involved the absolute rejection of authority, the cherishing of the keenest I5 skepticism, the annihilation of the spirit of blind faith; and the most ardent votary of science holds his firmest convictions, not because the men he most venerates hold them; not because their verity is testified by portents and wonders; but because his experience teaches him that 20 whenever he chooses to bring these convictions into contact with their primary source, Nature-whenever he thinks fit to test them by appealing to experiment and to observation-Nature will confirm them. The man of science has learned to believe in justification, not by 25 faith, but by verification.

Thus, without for a moment pretending to despise the practical results of the improvement of natural knowledge, and its beneficial influence on material civilization, it must, I think, be admitted that the great ideas, some 30 of which I have indicated, and the ethical spirit which I have endeavored to sketch, in the few moments which remained at my disposal, constitute the real and permanent significance of natural knowledge. 
If these ideas be destined, as I believe they are, to be more and more firmly established as the world grows older; if that spirit be fated, as I believe it is, to extend itself into all departments of human thought, and to 5 become co-extensive with the range of knowledge; if, as our race approaches its maturity, it discovers, as I believe it will, that there is but one kind of knowledge and but one method of acquiring it; then we, who are still children, may justly feel it our highest duty to recognize Io the advisableness of improving natural knowledge, and so to aid ourselves and our successors in their course towards the noble goal which lies before mankind. 


\section{A LIBERAL EDUCATION: AND WHERE TO FIND IT}

\section{(1868)}

The business which the South London Working Men's College has undertaken is a great work; indeed, I might say, that education, with which that college proposes to grapple, is the greatest work of all those which lie ready to a man's hand just at present.

And, at length, this fact is becoming generally recognized. You cannot go anywhere without hearing a buzz of more or less confused and contradictory talk on this subject-nor can you fail to notice that, in one point at any rate, there is a very decided advance upon like dis- ro cussions in former days. Nobody outside the agricultural interest now dares to say that education is a bad thing. If any representative of the once large and powerful party, which, in former days, proclaimed this opinion, still exists in a semi-fossil state, he keeps his thoughts 15 to himself. In fact, there is a chorus of voices, almost distressing in their harmony, raised in favor of the doctrine that education is the great panacea for human troubles, and that, if the country is not shortly to go to the dogs, everybody must be educated.

The politicians tell us, "you must educate the masses because they are going to be masters." The clergy join in the cry for education, for they affirm that the people are drifting away from church and chapel into the broad- 
est infidelity. The manufacturers and the capitalists swell the chorus lustily. They declare that ignorance makes bad workmen; that England will soon be unable to turn out cotton goods, or steam engines, cheaper than 5 other people; and then, Ichabod! Ichabod! the glory will be departed from us. And a few voices are lifted up in favor of the doctrine that the masses should be educated because they are men and women with unlimited capacities of being, doing, and suffering, and that it is as true now, Io as ever it was, that the people perish for lack of knowledge.

These members of the minority, with whom I confess I have a good deal of sympathy, are doubtful whether any of the other reasons urged in favor of the education of the people are of much value-whether, indeed, some I5 of them are based upon either wise or noble grounds of action. They question if it be wise to tell people that you will do for them, out of fear of their power, what you have left undone, so long as your only motive was compassion for their weakness and their sorrows. And, if

20 ignorance of everything which it is needful a ruler should know is likely to do so much harm in the governing classes of the future, why is it, they ask reasonably enough, that such ignorance in the governing classes of the past has not been viewed with equal horror?

25 Compare the average artisan and the average country squire, and it may be doubted if you will find a pin to choose between the two in point of ignorance, class feeling, or prejudice. It is true that the ignorance is of a different sort-that the class feeling is in favor of a different 30 class, and that the prejudice has a distinct flavor of wrongheadedness in each case-but it is questionable if the one is either a bit better, or a bit worse, than the other. The old protectionist theory is the doctrine of trades unions as applied by the squires, and the modern trades unionism 
is the doctrine of the squires applied by the artisans. Why should we be worse off under one régime than under the other?

Again, this skeptical minority asks the clergy to think whether it is really want of education which keeps the 5 masses away from their ministrations-whether the most completely educated men are not as open to reproach on this score as the workmen; and whether, perchance, this may not indicate that it is not education which lies at the bottom of the matter.

Once more, these people, whom there is no pleasing, venture to doubt whether the glory, which rests upon being able to undersell all the rest of the world, is a very safe kind of glory-whether we may not purchase it too dear; especially if we allow education, which ought to 15 be directed to the making of men, to be diverted into a process of manufacturing human tools, wonderfully adroit in the exercise of some technical industry, but good for nothing else.

And, finally, these people inquire whether it is the 20 masses alone who need a reformed and improved education. They ask whether the richest of our public schools might not well be made to supply knowledge, as well as gentlemanly habits, a strong class feeling, and eminent proficiency in cricket. They seem to think that the noble 25 foundations of our old universities are hardly fulfilling their functions in their present posture of half-clerical seminaries, half racecourses, where men are trained to win a senior wranglership, or a double-first, as horses are trained to win a cup, with as little reference to the needs 30 of after-life in the case of the man as in that of the racer. And, while as zealous for education as the rest, they affirm that, if the education of the richer classes were such as to fit them to be the leaders and the governors 
of the poorer; and, if the education of the poorer classes were such as to enable them to appreciate really wise guidance and good governance; the politicians need not fear mob-law, nor the clergy lament their want of flocks, 5 nor the capitalists prognosticate the annihilation of the prosperity of the country.

Such is the diversity of opinion upon the why and the wherefore of education. And my hearers will be prepared to expect that the practical recommendations which are Io put forward are not less discordant. There is a loud cry for compulsory education. We English, in spite of constant experience to the contrary, preserve a touching faith in the efficacy of acts of parliament; and I believe we should have compulsory education in the course of I5 next session, if there were the least probability that half a dozen leading statesmen of different parties would agree what that education should be.

Some hold that education without theology is worse than none. Others maintain, quite as strongly, that educa20 tion with theology is in the same predicament. But this is certain, that those who hold the first opinion can by no means agree what theology should be taught; and that those who maintain the second are in a small minority.

At any rate "make people learn to read, write, and 25 cipher," say a great many; and the advice is undoubtedly sensible as far as it goes. But, as has happened to me in former days, those who, in despair of getting anything better, advocate this measure, are met with the objection that it is very like making a child practise the use 30 of a knife, fork, and spoon, without giving it a particle of meat. I really don't know what reply is to be made to such an objection.

But it would be unprofitable to spend more time in disentangling, or rather in showing up the knots in the 
raveled skein of our neighbors. Much more to the purpose is it to ask if we possess any clue of our own which may guide us among these entanglements. And by way of a beginning, let us ask ourselves-What is education? Above all things, what is our ideal of a 5 thoroughly liberal education? - of that education which, if we could begin life again, we would give ourselvesof that education which, if we could mold the fates to our own will, we would give our children. Well, I know not what may be your conceptions upon this matter, Io but I will tell you mine, and I hope I shall find that our views are not very discrepant.

Suppose it were perfectly certain that the life and fortune of every one of us would, one day or other, depend upon his winning or losing a game at chess. Don't 15 you think that we should all consider it to be a primary duty to learn at least the names and the moves of the pieces; to have a notion of a gambit, and a keen eye for all the means of giving and getting out of check? Do you not think that we should look with a disapprobation 20 amounting to scorn, upon the father who allowed his son, or the state which allowed its members, to grow up without knowing a pawn from a knight?

Yet it is a very plain and elementary truth, that the life, the fortune, and the happiness of every one of us, 25 and, more or less, of those who are connected with us, do depend upon our knowing something of the rules of a game infinitely more difficult and complicated than chess. It is a game which has been played for untold ages, every man and woman of us being one of the two players in a 30 game of his or her own. The chess-board is the world, the pieces are the phenomena of the universe, the rules of the game are what we call the laws of Nature. The 
player on the other side is hidden from us. We know that his play is always fair, just, and patient. But also we know, to our cost, that he never overlooks a mistake, or makes the smallest allowance for ignorance. To the 5 man who plays well, the highest stakes are paid, with that sort of overflowing generosity with which the strong shows delight in strength. Andeone who plays ill is checkmated-without haste, but without remorse.

My metaphor will remind some of you of the famous ro picture in which Retzsch has depicted Satan playing at chess with man for his soul. Substitute for the mocking fiend in that picture, a calm, strong angel who is playing for love, as we say, and would rather lose than win-and I should accept it as an image of human life.

15- Well, what I mean by education is learning the rules of this mighty game. In other words, education is the instruction of the intellect in the laws of Nature, under which name $I$ include not merely things and their forces, but men and their ways; and the fashioning of the affec20 tions and of the will into an earnest and loving desire to move in harmony with those laws. For me education means neither more nor less than this. Anything which professes to call itself education must be tried by this standard, and if it fails to stand the test, I will not call 25 it education, whatever may be the force of authority, or of numbers, upon the other side.

It is important to remember that, in strictness, there is no such thing as an uneducated man. Take an extreme case. Suppose that an adult man, in the full vigor of 30 his faculties, could be suddenly placed in the world, as Adam is said to have been, and then left to do as he best might. How long would he be left uneducated? Not five minutes. Nature would begin to teach him, through the eye, the ear, the touch, the properties of objects. Pain 
and pleasure would be at his elbow telling him to do this and avoid that; and by slow degrees the man would receive an education, which, if narrow, would be thorough, real, and adequate to his circumstances, though there would be no extras and very few accomplishments. 5

And if to this solitary man entered a second Adam, or, better still, an Eve, anew and greater world, that of social and moral phenomena, would be revealed. Joys and woes, compared with which all others might seem but faint shadows, would spring from the newrelations. Hap- Io piness and sorrow would take the place of the coarser monitors, pleasure and pain; but conduct would still be shaped by the observation of the natural consequences of actions; or, in other words, by the laws or the nature of man.

To every one of us the world was once as fresh and new as to Adam. And then, long before we were susceptible of any other mode of instruction, Nature took us in hand, and every minute of waking life brought its educational influence, shaping our actions into rough ac- 20 cordance with Nature's laws, so that we might not be ended untimely by too gross disobedience. Nor should I speak of this process of education as past, for any one, be he as old as he may. For every man, the world is as fresh as it was at the first day, and as full of untold 25 novelties for him who has the eyes to see them. And Nature is still continuing her patient education of us in that great university, the universe, of which we are all members-Nature having no Test-Acts.

Those who take honors in Nature's university, who 30 learn the laws which govern men and things and obey them, are the really great and successful men in this world. The great mass of mankind are the "Poll," who pick up just enough to get through without much dis- 
credit. Those who won't learn at all are plucked; and then you can't come up again. Nature's pluck means extermination.

Thus the question of compulsory education is settled 5 so far as Nature is concerned. Her bill on that question was framed and passed long ago. But, like all compulsory legislation, that of Nature is harsh and wasteful in its operation. Ignorance is visited as sharply as wilful disobedience-incapacity meets with the same punishment Io as crime. Nature's discipline is not even a word and a blow, and the blow first; but the blow without the word. It is left to you to find out why your ears are. boxed.

The object of what we commonly call education-that I5 education in which man intervenes and which I shall distinguish as artificial education-is to make good these defects in Nature's methods; to prepare the child to receive Nature's education, neither incapably nor ignorantly, nor with wilful disobedience; and to understand 20 the preliminary symptoms of her displeasure, without waiting for the box on the ear. In short, all artificial education ought to be an anticipation of natural education. And a liberal education is an artificial education, which has not only prepared a man to escape the great 25 evils of disobedience to natural laws, but has trained him to appreciate and to seize upon the rewards, which Nature scatters with as free a hand as her penalties.

That man, I think, has had a liberal education, who has been so trained in youth that his body is the ready 30 servant of his will, and does with ease and pleasure all the work that, as a mechanism, it is capable of; whose intellect is a clear, cold, logic engine, with all its parts of equal strength, and in smooth working order; ready, like a steam engine, to be turned to any kind of work, 
and spin the gossamers as well as forge the anchors of the mind; whose mind is stored with a knowledge of the great and fundamental truths of Nature and of the laws of her operations; one who, no stunted ascetic, is full of life and fire, but whose passions are trained to come 5 to heel by a vigorous will, the servant of a tender conscience; who has learned to love all beauty, whether of Nature or of art, to hate all vileness, and to respect others as himself.

Such an one and no other, I conceive, has had a liberal ro education; for he is, as completely as a man can be, in harmony with Nature. He will make the best of her, and she of him. They will get on together rarely; she as his ever beneficent mother; he as her mouth-piece, her conscious self, her minister and interpreter.

Where is such an education as this to be had? Where is there any approximation to it? Has any one tried to found such an education? Looking over the length and breadth of these islands, I am afraid that all these questions must receive a negative answer. Consider our 20 primary schools, and what is taught in them. A child learns:-

I. To read, write, and cipher, more or less well; but in a very large proportion of cases not so well as to take pleasure in reading, or to be able to write the commonest 25 letter properly.

2. A quantity of dogmatic theology, of which the child, nine times out of ten, understands next to nothing.

3. Mixed up with this, so as to seem to stand or fall with it, a few of the broadest and simplest principles of 30 morality. This, to my mind, is much as if a man of science should make the story of the fall of the apple in Newton's garden an integral part of the doctrine of 
gravitation, and teach it as of equal authority with the law of the inverse squares.

4. A good deal of Jewish history and Syrian geography, and, perhaps, a little something about English history 5 and the geography of the child's own country. But I doubt if there is a primary school in England in which hangs a map of the hundred in which the village lies, so that the children may be practically taught by it what a map means.

Io 5. A certain amount of regularity, attentive obedience, respect for others: obtained by fear, if the master be incompetent or foolish; by love and reverence, if he be wise.

So far as this school course embraces a training in the theory and practice of obedience to the moral laws I5 of Nature, I gladly admit, not only that it contains a valuable educational element, but that, so far, it deals with the most valuable and important part of all education. Yet, contrast what is done in this direction with what might be done; with the time given to matters of 20 comparatively no importance; with the absence of any attention to things of the highest moment; and one is tempted to think of Falstaff's bill and "the halfpenny worth of bread to all that quantity of sack."

Let us consider what a child thus "educated" knows, 25 and what it does not know. Begin with the most important topic of all-morality, as the guide of conduct. The child knows well enough that some acts meet with approbation and some with disapprobation. But it has never. heard that there lies in the nature of things a 30 reason for every moral law, as cogent and as well defined as that which underlies every physical law; that stealing and lying are just as certain to be followed by evil consequences, as putting your hand in the fire, or jumping out of a garret window. Again, though the scholar may 


\section{A Liberal Education}

have been made acquainted, in dogmatic fashion, with the broad laws of morality, he has had no training in the application of those laws to the difficult problems which result from the complex conditions of modern civilization. Would it not be very hard to expect any one to solve 5 a problem in conic sections who had merely been taught the axioms and definitions of mathematical science?

A workman has to bear hard labor, and perhaps privation, while he sees others rolling in wealth, and feeding their dogs with what would keep his children from starva- Io tion. Would it not be well to have helped that man to calm the natural promptings of discontent by showing him, in his youth, the necessary connection of the moral law which prohibits stealing with the stability of societyby proving to him, once for all, that it is better for his 15 own people, better for himself, better for future generations, that he should starve than steal? If you have no foundation of knowledge, or habit of thought, to work upon, what chance. have you of persuading a hungry man that a capitalist is not a thief "with a circum- 20 bendibus"? And if he honestly believes that, of what avail is it to quote the commandment against stealing, when he proposes to make the capitalist disgorge?

Again, the child learns absolutely nothing of the history or the political organization of his own country. His 25 general impression is, that everything of much importance happened a very long while ago; and that the Queen and the gentlefolks govern the country much after the fashion of King David and the elders and nobles of Israel-his sole models. Will you give a man with this 30 much information a vote? In easy times he sells it for a pot of beer. Why should he not? It is of about as much use to him as a chignon, and he knows as much what to do with it, for any other purpose. In bad times, 
on the contrary, he applies his simple theory of government, and believes that his rulers are the cause of his sufferings-a belief which sometimes bears remarkable practical fruits.

5 Least of all, does the child gather from this primary "education" of ours a conception of the laws of the physical world, or of the relations of cause and effect therein. And this is the more to be lamented, as the poor are especially exposed to physical evils, and are Io more interested in removing them than any other class of the community. If any one is concerned in knowing the ordinary laws of mechanics one would think it is the hand-laborer, whose daily toil lies among levers and pulleys; or among the other implements of artisan work. I5 And if any one is interested in the laws of health, it is the poor workman, whose strength is wasted by ill-prepared food, whose health is sapped by bad ventilation and bad drainage, and half whose children are massacred by disorders which might be prevented. Not only does our 20 present primary education carefully abstain from hinting to the workman that some of his greatest evils are traceable to mere physical agencies, which could be removed by energy, patience, and frugality; but it does worseit renders him, so far as it can, deaf to those who could 25 help him, and tries to substitute an Oriental submission to what is falsely declared to be the will of God, for his natural tendency to strive after a better condition.

What wonder, then, if very recently an appeal has been made to statistics for the profoundly foolish pur30 pose of showing that education is of no good-that it diminishes neither misery, nor crime, among the masses of mankind? I reply, why should the thing which has been called education do either the one or the other? If I am a knave or a fool, teaching me to read and write 


\section{A Liberal Education}

won't make me less of either one or the other-unless somebody shows me how to put my reading and writing to wise and good purposes.

Suppose any one were to argue that medicine is of no use, because it could be proved statistically, that the 5 percentage of deaths was just the same, among people who had been taught how to open a medicine chest, and among those who did not so much as know the key by sight. The argument is absurd; but it is not more preposterous than that against which I am contending. The ro only medicine for suffering, crime, and all the other woes of mankind, is wisdom. Teach a man to read and write, and you have put into his hands the great keys of the wisdom box. But it is quite another matter whether he ever opens the box or not. And he is as likely to poison I5 as to cure himself, if, without guidance, he swallows the first drug that comes to hand. In these times a man may as well be purblind, as unable to read-lame, as unable to write. But I protest that, if I thought the alternative were a necessary one, I would rather that 20 the children of the poor should grow up ignorant of both these mighty arts, than that they should remain ignorant of that knowledge to which these arts are means.

It may be said that all these animadversions may 25 apply to primary schools, but that the higher schools, at any rate, must be allowed to give a liberal education. In fact, they professedly sacrifice everything else to this object.

Let us inquire into this matter. What do the higher 30 schools, those to which the great middle class of the country sends its children, teach, over and above the instruction given in the primary schools? There is a little 
more reading and writing of English. But, for all that, every one knows that it is a rare thing to find a boy of the middle or upper classes who can read aloud decently, or who can put his thoughts on paper in clear and gram5 matical (to say nothing of good or elegant) language. The "ciphering" of the lower schools expands into elementary mathematics in the higher; into arithmetic, with a little algebra, a little Euclid. But I doubt if one boy in five hundred has ever heard the explanation of a rule Io of arithmetic, or knows his Euclid otherwise than by rote.

Of theology, the middle class schoolboy gets rather less than poorer children, less absolutely and less relatively, because there are so many other claims upon his 15 attention. I venture to say that, in the great majority of cases, his ideas on this subject when he leaves school are of the most shadowy and vague description, and associated with painful impressions of the weary hours spent in learning collects and catechism by heart.

20 Modern geography, modern history, modern literature, the English language as a language; the whole circle of the sciences, physical, moral, and social, are even more completely ignored in the higher than in the lower schools. Up till within a few years back, a boy might have passed 25 through any one of the great public schools with the greatest distinction and credit, and might never so much as have heard of one of the subjects I have just mentioned. He might never have heard that the earth goes round the sun; that England underwent a great revolu30 tion in 1688, and France another in 1789; that there once lived certain notable men called Chaucer, Shakespeare, Milton, Voltaire, Goethe, Schiller. The first might be a German and the last an Englishman for anything he could tell you to the contrary. And as for 
science, the only idea the word would suggest to his mind would be dexterity in boxing.

I have said that this was the state of things a few years back, for the sake of the few righteous who are to be found among the educational cities of the plain. 5 But I would not have you too sanguine about the result, if you sound the minds of the existing generation of public schoolboys, on such topics as those I have mentioned.

Now let us pause to consider this wonderful state of ro affairs; for the time will come when Englishmen will quote it as the stock example of the stolid stupidity of their ancestors in the nineteenth century. The most thoroughly commercial people, the greatest voluntary wanderers and colonists the world has ever seen, are ${ }_{5} 5$ precisely the middle classes of this country. If there be a people which has been busy making history on the great scale for the last three hundred years-and the most profoundly interesting history-history which, if it happened to be that of Greece or Rome, we should 20 study with avidity - it is the English. If there be a people which, during the same period, has developed a remarkable literature, it is our own. If there be a nation whose prosperity depends absolutely and wholly upon their mastery over the forces of Nature, upon their in- 25 telligent apprehension of, and obedience to, the laws of the creation and distribution of wealth, and of the stable equilibrium of the forces of society, it is precisely this nation. And yet this is what these wonderful people tell their sons:- "At the cost of from one to two thou- 30 sand pounds of our hard earned money, we devote twelve of the most precious years of your lives to school. There you shall toil, or be supposed to toil; but there you shall not learn one single thing of all those you will most 
want to know, directly you leave school and enter upon the practical business of life. You will in all probability go into business, but you shall not know where, or how, any article of commerce is produced, or the dif5 ference between an export or an import, or the meaning of the word 'capital.' You will very likely settle in a colony, but you shall not know whether Tasmania is part of New South Wales, or vice versâ.

"Very probably you may become a manufacturer, but Io you shall not be provided with the means of understanding the working of one of your own steam-engines, or the nature of the raw products you employ; and, when you are asked to buy a patent, you shall not have the slightest means of judging whether the inventor is 15 an impostor who is contravening the elementary principles of science, or a man who will make you as rich as Crœsus.

"You will very likely get into the House of Commons. You will have to take your share in making laws which 20 may prove a blessing or a curse to millions of men. But you shall not hear one word respecting the political organization of your country; the meaning of the controversy between freetraders and protectionists shall never have been mentioned to you; you shall not so much as 25 know that there are such things as economic laws.

"The mental power which will be of most importance in your daily life will be the power of seeing things as they are without regard to authority; and of drawing accurate general conclusions from particular facts. But 30 at school and at college you shall know of no source of truth but authority; nor exercise your reasoning faculty upon anything but deduction from that which is laid down by authority.

"You will have to weary your soul with work, and 
many a time eat your bread in sorrow and in bitterness, and you shall not have learned to take refuge in the great source of pleasure without alloy, the serene restingplace for worn human nature,- the world of art."

Said I not rightly that we are a wonderful people? 5 I am quite prepared to allow, that education entirely devoted to these omitted subjects might not be a completely liberal education. But is an education which ignores them all, a liberal education? Nay, is it too much to say that the education which should embrace these sub- 10 jects and no others, would be a real education, though an incomplete one; while an education which omits them is really not an education at all, but a more or less useful course of intellectual gymnastics?

For what does the middle-class school put in the place 15 of all these things which are left out? It substitutes what is usually comprised under the compendious title of the "classics"-that is to say, the languages, the literature, and the history of the ancient Greeks and Romans, and the geography of so much of the world 20 as was known to these two great nations of antiquity. Now, do not expect me to depreciate the earnest and enlightened pursuit of classical learning. I have not the least idea to speak ill of such occupations, nor any sympathy with those who run them down. On the 25 contrary, if my opportunities had lain in that direction, there is no investigation into which I could have thrown myself with greater delight than that of antiquity.

What science can present greater attractions than philology? How can a lover of literary excellence fail 30 to rejoice in the ancient masterpieces? And with what consistency could I, whose business lies so much in the attempt to decipher the past, and to build up intelligible 
forms out of the scattered fragments of long-extinct beings, fail to take a sympathetic, though an unlearned, interest in the labors of a Niebuhr, a Gibbon, or a Grote? Classical history is a great section of the paleontology of $5 \mathrm{man}$; and I have the same double respect for it as for other kinds of paleontology - that is to say, a respect for the facts which it establishes as for all facts, and a still greater respect for it as a preparation for the discovery of a law of progress.

Io But if the classics were taught as they might be taught-if boys and girls were instructed in Greek and Latin, not merely as languages, but as illustrations of philological science; if a vivid picture of life on the shores of the Mediterranean, two thousand years ago, I5 were imprinted on the minds of scholars; if ancient history were taught, not as a weary series of feuds and fights, but traced to its causes in such men placed under such conditions; if, lastly, the study of the classical books were followed in such a manner as to impress boys with 20 their beauties, and with the grand simplicity of their statement of the everlasting problems of human life, instead of with their verbal and grammatical peculiarities; I still think it as little proper that they should form the basis of a liberal education for our contemporaries, as 25 I should think it fitting to make that sort of paleontology with which I am familiar, the backbone of modern education.

It is wonderful how close a parallel to classical training could be made out of that paleontology to which I 30 refer. In the first place I could get up an osteological primer so arid, so pedantic in its terminology, so altogether distasteful to the youthful mind, as to beat the recent famous production of the head-masters out of the field in all these excellences. Next, I could exercise my 


\section{A Liberal Education}

boys upon easy fossils, and bring out all their powers of memory and all their ingenuity in the application of my osteo-grammatical rules to the interpretation, or construing, of those fragments. To those who had reached the higher classes, I might supply odd bones to be built 5 up into animals, giving great honor and reward to him who succeeded in fabricating monsters most entirely in accordance with the rules. That would answer to versemaking and essay-writing in the dead languages.

To be sure, if a great comparative anatomist were to ro look at these fabrications he might shake his head or laugh. But what then? Would such a catastrophe destroy the parallel? What think you would Cicero, or Horace, say to the production of the best sixth form going? And would not Terence stop his ears and run 15 out if he could be present at an English performance of his own plays? Would Hamlet, in the mouths of a set of French actors, who should insist on pronouncing English after the fashion of their own tongue, be more hideously ridiculous?

But it will be said that I am forgetting the beauty, and the human interest, which appertain to classical studies. To this I reply that it is only a very strong man who can appreciate the charms of a landscape, as he is toiling up a steep hill, along a bad road. What with short- 25 windedness, stones, ruts, and a pervading sense of the wisdom of rest and be thankful, most of us have little enough sense of the beautiful under these circumstances. The ordinary schoolboy is precisely in this case. He finds Parnassus uncommonly steep, and there is no chance of 30 his having much time or inclination to look about him till he gets to the top. And nine times out of ten he does not get to the top.

But if this be a fair picture of the results of classical 


\section{Selections from Huxley}

teaching at its best-and I gather from those who have authority to speak on such matters that it is so-what is to be said of classical teaching at its worst, or in other words, of the classics of our ordinary middle-class 5 schools? * I will tell you. It means getting up endless forms and rules by heart. It means turning Latin and Greek into English, for the mere sake of being able to do it, and without the smallest regard to the worth, or worthlessness, of the author read. It means the learnIo ing of innumerable, not always decent, fables in such a shape that the meaning they once had is dried up into utter trash; and the only impression left upon a boy's mind is, that the people who believed such things must have been the greatest idiots the world ever saw. And

I5 it means, finally, that after a dozen years spent at this kind of work, the sufferer shall be incompetent to interpret a passage in an author he has not already got up; that he shall loathe the sight of a Greek or Latin book; and that he shall never open, or think of, a classical writer 20 again, until, wonderful to relate, he insists upon submitting his sons to the same process.

These be your gods, O Israel! For the sake of this net result (and respectability) the British father denies his children all the knowledge they might turn to account 25 in life, not merely for the achievement of vulgar success, but for guidance in the great crises of human existence. This is the stone he offers to those whom he is bound by the strongest and tenderest ties to feed with bread.

If primary and secondary education are in this un30 satisfactory state, what is to be said to the universities? This is an awful subject, and one I almost fear to touch

* For a justification of what is here said about these schools, see that valuable book, Essays on a Liberal Education. 
with my unhallowed hands; but I can tell you what those say who have authority to speak.

The Rector of Lincoln College, in his lately published valuable Suggestions for Academical Organization with Especial Reference to Oxford, tells us (p. 127):

"The colleges were, in their origin, endowments, not for the elements of a general liberal education, but for the prolonged study of special and professional faculties by men of riper age. The universities embraced both these objects. The colleges, while they incidentally aided in Io elementary education, were specially devoted to the highest learning. . . .

"This was the theory of the middle-age university and the design of collegiate foundations in their origin. Time and circumstances have brought about a total change. 15 The colleges no longer promote the researches of science, or direct professional study. Here and there college walls may shelter an occasional student, but not in larger proportions than may be found in private life. Elementary teaching of youths under twenty is now the only function 20 performed by the university, and almost the only object of college endowments. Colleges were homes for the lifestudy of the highest and most abstruse parts of knowledge. They have become boarding schools in which the elements of the learned languages are taught to 25 youths."

If Mr. Pattison's high position, and his obvious love and respect for his university, be insufficient to convince the outside world that language so severe is yet no more than just, the authority of the Commissioners who re- 30 ported on the University of Oxford in 1850 is open to no challenge. Yet they write:-

"It is generally acknowledged that both Oxford and the country at large suffer greatly from the absence of a 
body of learned men devoting their lives to the cultivation of science, and to the direction of academical education.

"The fact that so few books of profound research emanate from the University of Oxford, materially im5 pairs its character as a seat of learning, and consequently its hold on the respect of the nation."

Cambridge can claim no exemption from the reproaches addressed to Oxford. And thus there seems no escape from the admission that what we fondly call our great Io seats of learning are simply "boarding schools" for bigger boys; that learned men are not more numerous in them than out of them; that the advancement of knowledge is not the object of fellows of colleges; that, in the philosophic calm and meditative stillness of their green-

I5 swarded courts, philosophy does not thrive, and meditation bears few fruits.

It is my great good fortune to reckon amongst my friends resident members of both universities, who are men of learning and research, zealous cultivators of 20 science, keeping before their minds a noble ideal of a university, and doing their best to make that ideal a reality ; and, to me, they would necessarily typify the universities, did not the authoritative statements I have quoted compel me to believe that they are exceptional, 25 and not representative men. Indeed, upon calm consideration, several circumstances lead me to think that the Rector of Lincoln College and the Commissioners cannot be far wrong.

I believe there can be no doubt that the foreigner 30 who should wish to become acquainted with the scientific, or the literary, activity of modern England, would simply lose his time and his pains if he visited our universities with that object.

And, as for works of profound research on any subject, 
and, above all, in that classical lore for which the universities profess to sacrifice almost everything else, why, a third-rate, poverty-stricken German university turns out more produce of that kind in one year, than our vast and wealthy foundations elaborate in ten.

Ask the man who is investigating any question, profoundly and thoroughly-be it historical, philosophical, philological, physical, literary, or theological; who is trying to make himself master of any abstract subject (except, perhaps, political economy and geology, both of which to are intensely Anglican sciences), whether he is not compelled to read half a dozen times as many German, as English, books? And whether, of these English books, more than one in ten is the work of a fellow of a college, or a professor of an English university?

Is this from any lack of power in the English as compared with the German mind? The countrymen of Grote and of Mill, of Faraday, of Robert Brown, of Lyell, and of Darwin, to go no further back than the contemporaries of men of middle age, can afford to smile at such a sug- 20 gestion. England can show now, as she has been able to show in every generation since civilization spread over the West, individual men who hold their own against the world, and keep alive the old tradition of her intellectual eminence.

But, in the majority of cases, these men are what they are in virtue of their native intellectual force, and of a strength of character which will not recognize impediments. They are not trained in the courts of the Temple of Science, but storm the walls of that edifice in all sorts of 30 irregular ways, and with much loss of time and power, in order to obtain their legitimate positions.

Our universities not only do not encourage such men; do not offer them positions, in which it should be their 
highest duty to do, thoroughly, that which they are most capable of doing; but, as far as possible, university training shuts out of the minds of those among them, who are subjected to it, the prospect that there is anything in 5 the world for which they are specially fitted. Imagine the success of the attempt to still the intellectual hunger of any of the men I have mentioned, by putting before him, as the object of existence, the successful mimicry of the measure of a Greek song, or the roll of Ciceronian Io prose! Imagine how much success would be likely to attend the attempt to persuade such men, that the education which leads to perfection in such elegancies is alone to be called culture; while the facts of history, the process of thought, the conditions of moral and social existence, I5 and the laws of physical nature, are left to be dealt with as they may, by outside barbarians!

It is not thus that the German universities, from being beneath notice a century ago, have become what they are now-the most intensely cultivated and the most pro20 ductive intellectual corporations the world has ever seen.

The student who repairs to them sees in the list of classes and of professors a fair picture of the world of knowledge. Whatever he needs to know there is some one ready to teach him, some one competent to discipline $25 \mathrm{him}$ in the way of learning; whatever his special bent, let him but be able and diligent, and in due time he shall find distinction and a career. Among his professors, he sees men whose names are known and revered throughout the civilized world; and their living example infects 30 him with a noble ambition, and a love for the spirit of work.

The Germans dominate the intellectual world by virtue of the same simple secret as that which made Napoleon the master of old Europe. They have declared la carrière 


\section{A Liberal Education}

ouverte aux talents, and every Bursch marches with a professor's gown in his knapsack. Let him become a great scholar, or man of science, and ministers will compete for his services. In Germany, they do not leave the chance of his holding the office he would render illustrious to the 5 tender mercies of a hot canvass, and the final wisdom of a mob of country parsons.

In short, in Germany, the universities are exactly what the Rector of Lincoln and the Commissioners tell us the English universities are not; that is to say, corporations ro "of learned men devoting their lives to the cultivation of science, and the direction of academical education." They are not "boarding schools for youths," nor clerical seminaries; but institutions for the higher culture of men, in which the theological faculty is of no more im- 15 portance, or prominence, than the rest; and which are truly "universities," since they strive to represent and embody the totality of human knowledge, and to find room for all forms of intellectual activity.

May zealous and clear-headed reformers like Mr. Pat- 20 tison succeed in their noble endeavors to shape our universities towards some such ideal as this, without losing what is valuable and distinctive in their social tone! But until they have succeeded, a liberal education will be no more obtainable in our Oxford and Cambridge 25 Universities than in our public schools.

If I am justified in my conception of the ideal of a liberal education; and if what I have said about the existing educational institutions of the country is also true, it is clear that the two have no sort of relation 30 to one another; that the best of our schools and the most complete of our university trainings give but a narrow, one-sided, and essentially illiberal education-while the 
worst give what is really next to no education at all. The South London Working Men's College could not copy any of these institutions if it would. I am bold enough to express the conviction that it ought not if it 5 could.

For what is wanted is the reality and not the mere name of a liberal education; and this College must steadily set before itself the ambition to be able to give that education sooner or later. At present we are but beginning, Io sharpening our educational tools, as it were, and, except a modicum of physical science, we are not able to offer much more than is to be found in an ordinary school.

Moral and social science-one of the greatest and most fruitful of our future classes, I hope-at present lacks I5 only one thing in our program, and that is a teacher. A considerable want, no doubt; but it must be recollected that it is much better to want a teacher than to want the desire to learn.

Further, we need what, for want of a better name, 20 I must call physical geography. What I mean is that which the Germans call "Erdkunde." It is a description of the earth, of its place and relation to other bodies; of its general structure, and of its great features-winds, tides, mountains, plains; of the chief forms of the vege25 table and animal worlds, of the varieties of man. It is the peg upon which the greatest quantity of useful and entertaining scientific information can be suspended.

Literature is not upon the College program; but I hope some day to see it there. For literature is the 30 greatest of all sources of refined pleasure, and one of the great uses of a liberal education is to enable us to enjoy that pleasure. There is scope enough for the purposes of liberal education in the study of the rich treasures of our own language alone. All that is needed is direction, 


\section{A Liberal Education}

and the cultivation of a refined taste by attention to sound criticism. But there is no reason why French and German should not be mastered sufficiently to read what is worth reading in those languages, with pleasure and with profit.

And finally, by-and-by, we must have history; treated not as a succession of battles and dynasties; not as a series of biographies; not as evidence that Providence has always been on the side of either Whigs or Tories; but as the development of man in times past, and in other condi- ro tions than our own.

But, as it is one of the principles of our College to be self-supporting, the public must lead, and we must follow, in these matters. If my hearers take to heart what I have said about liberal education, they will desire these things, I5 and I doubt not we shall be able to supply them. But we must wait till the demand is made. 


\section{ON A PIECE OF CHALK}

\section{( 1868$)$}

If a well were to be sunk at our feet in the midst of the city of Norwich, the diggers would very soon find themselves at work in that white substance almost too soft to be called rock, with which we are all familiar as 5 "chalk."

Not only here, but over the whole county of Norfolk, the well-sinker might carry his shaft down many hundred feet without coming to the end of the chalk; and, on the sea-coast, where the waves have pared away the face Io of the land which breasts them, the scarped faces of the high cliffs are often wholly formed of the same material. Northward, the chalk may be followed as far as Yorkshire; on the south coast it appears abruptly in the picturesque western bays of Dorset, and breaks into the I5 Needles of the Isle of Wight; while on the shores of Kent it supplies that long line of white cliffs to which England owes her name of Albion.

Were the thin soil which covers it all washed away, a curved band of white chalk, here broader, and there 20 narrower, might be followed diagonally across England from Lulworth in Dorset, to Flamborough Head in Yorkshire-a distance of over 280 miles as the crow flies.

From this band to the North Sea, on the east, and the ${ }_{25}$ Channel, on the south, the chalk is largely hidden by other deposits; but, except in the Weald of Kent and 
Sussex, it enters into the very foundation of all the south-eastern counties.

Attaining, as it does in some places, a thickness of more than a thousand feet, the English chalk must be admitted to be a mass of considerable magnitude. Never- 5 theless, it covers but an insignificant portion of the whole area occupied by the chalk formation of the globe, which has precisely the same general characters as ours, and is found in detached patches, some less, and others more extensive, than the English.

Chalk occurs in north-west Ireland; it stretches over a large part of France,- - the chalk which underlies Paris being, in fact, a continuation of that of the London basin; it runs through Denmark and Central Europe, and extends southward to North Africa; while eastward, it 15 appears in the Crimea and in Syria, and may be traced as far as the shores of the Sea of Aral, in Central Asia.

If all the points at which true chalk occurs were circumscribed, they would lie within an irregular oval about 3,000 miles in long diameter-the area of which 20 would be as great as that of Europe, and would many times exceed that of the largest existing inland sea-the Mediterranean.

Thus the chalk is no unimportant element in the masonry of the earth's crust, and it impresses a peculiar 25 stamp, varying with the conditions to which it is exposed, on the scenery of the districts in which it occurs. The undulating downs and rounded coombs, covered with sweet-grassed turf, of our inland chalk country, have a peacefully domestic and mutton-suggesting prettiness, but 30 can hardly be called either grand or beautiful. But on our southern coasts, the wall-sided cliffs, many hundred feet high, with vast needles and pinnacles standing out in the sea, sharp and solitary enough to serve as perches for 
the wary cormorant, confer a wonderful beauty and grandeur upon the chalk headlands. And, in the East, chalk has its share in the formation of some of the most venerable of mountain ranges, such as the Lebanon.

5 What is this wide-spread component of the surface of the earth? and whence did it come?

You may think this no very hopeful inquiry. You may not unnaturally suppose that the attempt to solve such problems as these can lead to no result, save that ro of entangling the inquirer in vague speculations, incapable of refutation and of verification.

If such were really the case, I should have selected some other subject than a "piece of chalk" for my discourse. But, in truth, after much deliberation, I have I5 been unable to think of any topic which would so well enable me to lead you to see how solid is the foundation upon which some of the most startling conclusions of physical science rest.

A great chapter of the history of the world is written 20 in the chalk. Few passages in the history of man can be supported by such an overwhelming mass of direct and indirect evidence as that which testifies to the truth of the fragment of the history of the globe, which I hope to enable you to read, with your own eyes, to-night.

25 Let me add, that few chapters of human history have a more profound significance for ourselves. I weigh my words well when I assert, that the man who should know the true history of the bit of chalk which every carpenter carries about in his breeches-pocket, though ignorant of all 30 other history, is likely, if he will think his knowledge out to its ultimate results, to have a truer, and therefore a better, conception of this wonderful universe, and of man's relation to it, than the most learned student who 
is deep-read in the records of humanity and ignorant of those of Nature.

The language of the chalk is not hard to learn, not nearly so hard as Latin, if you only want to get at the broad features of the story it has to tell; and I pro- 5 pose that we now set to work to spell that story out together.

We all know that if we "burn" chalk the result is quicklime. Chalk, in fact, is a compound of carbonic acid gas, and lime, and when you make it very hot the ro carbonic acid flies away and the lime is left.

By this method of procedure we see the lime, but we do not see the carbonic acid. If, on the other hand, you were to powder a little chalk and drop it into a good deal of strong vinegar, there would be a great bubbling 15 and fizzing, and, finally, a clear liquid, in which no sign of chalk would appear. Here you see the carbonic acid in the bubbles; the lime, dissolved in the vinegar, vanishes from sight. There are a great many other ways of showing that chalk is essentially nothing but carbonic acid and 20 quicklime. Chemists enunciate the result of all the experiments which prove this, by stating that chalk is almost wholly composed of "carbonate of lime."

It is desirable for us to start from the knowledge of this fact, though it may not seem to help us very far 25 towards what we seek. For carbonate of lime is a widelyspread substance, and is met with under very various conditions. All sorts of limestones are composed of more or less pure carbonate of lime. The crust which is often deposited by waters which have drained through limestone 30 rocks, in the form of what are called stalagmites and stalactites, is carbonate of lime. Or, to take a more familiar example, the fur on the inside of the teakettle is carbonate of lime; and, for anything chemistry tells us, 
to the contrary, the chalk might be a kind of gigantic fur upon the bottom of the earth-kettle, which is kept pretty hot below.

Let us try another method of making the chalk tell 5 us its own history. To the unassisted eye chalk looks simply like a very loose and open kind of stone. But it is possible to grind a slice of chalk down so thin that you can see through it-until it is thin enough, in fact, to be examined with any magnifying power that may ro be thought desirable. A thin slice of the fur of a kettle might be made in the same way. If it were examined microscopically, it would show itself to be more or less distinctly laminated mineral substance and nothing more.

But the slice of chalk presents a totally different 15 appearance when placed under the microscope. The general mass of it is made up of very minute granules; but, imbedded in this matrix, are innumerable bodies, some smaller and some larger, but, on a rough average, not more than a hundredth of an inch in diameter, 20 having a well-defined shape and structure. A cubic inch of some specimens of chalk may contain hundreds of thousands of these bodies, compacted together with incalculable millions of the granules.

The examination of a transparent slice gives a good 25 notion of the manner in which the components of the chalk are arranged, and of their relative proportions. But, by rubbing up some chalk with a brush in water and then pouring off the milky fluid, so as to obtain sediments of different degrees of fineness, the granules 30 and the minute rounded bodies may be pretty well separated from one another, and submitted to microscopic examination, either as opaque or as transparent objects. By combining the views obtained in these various methods, each of the rounded bodies may be proved to be a beau- 
tifully-constructed calcareous fabric, made up of a number of chambers, communicating freely with one another. The chambered bodies are of various forms. One of the commonest is something like a badly-grown raspberry, being formed of a number of nearly globular chambers 5 of different sizes congregated together. It is called Globigerina, and some specimens of chalk consist of little else than Globigerine and granules.

Let us fix our attention upon the Globigerina. It is the spoor of the game we are tracking. If we can learn ro what it is and what are the conditions of its existence, we shall see our way to the origin and past history of the chalk.

A suggestion which may naturally enough present itself is, that these curious bodies are the result of some process 15 of aggregation which has taken place in the carbonate of lime; that, just as in winter the rime on our windows simulates the most delicate and elegantly arborescent foliage-proving that the mere mineral water may, under certain conditions, assume the outward form of organic 20 bodies-so this mineral substance, carbonate of lime, hidden away in the bowels of the earth, has taken the shape of these chambered bodies. I am not raising a merely fanciful and unreal objection. Very learned men, in former days, have even entertained the notion that all 25 the formed things found in rocks are of this nature; and if no such conception is at present held to be admissible, it is because long and varied experience has now shown that mineral matter never does assume the form and structure we find in fossils. If any one were to try to 30 persuade you that an oyster-shell (which is also chiefly composed of carbonate of lime) had crystallized out of sea-water, I suppose you would laugh at the absurdity. Your laughter would be justified by the fact that all ex- 
perience tends to show that oyster-shells are formed by the agency of oysters, and in no other way. And if there were no better reasons, we should be justified, on like grounds, in believing that Globigerina is not the product 5 of anything but vital activity.

Happily, however, better evidence in proof of the organic nature of the Globigerine than that of analogy is forthcoming. It so happens that calcareous skeletons, exactly similar to the Globigerince of the chalk, are being ro formed, at the present moment, by minute living creatures, which flourish in multitudes, literally more numerous than the sands of the sea-shore, over a large extent of that part of the earth's surface which is covered by the ocean.

The history of the discovery of these living Globi15 gerine, and of the part which they play in rock building, is singular enough. It is a discovery which, like others of no less scientific importance, has arisen, incidentally, out of work devoted to very different and exceedingly practical interests.

20 When men first took to the sea, they speedily learned to look out for shoals and rocks; and the more the burthen of their ships increased, the more imperatively necessary it became for sailors to ascertain with precision the depth of the waters they traversed. Out of this 25 necessity grew the use of the lead and sounding line; and, ultimately, marine-surveying, which is the recording of the form of coasts and of the depth of the sea, as ascertained by the sounding-lead, upon charts.

At the same time, it became desirable to ascertain 30 and to indicate the nature of the sea-bottom, since this circumstance greatly affects its goodness as holding ground for anchors. Some ingenious tar, whose name deserves a better fate than the oblivion into which it has fallen, attained this object by "arming" the bottom of the lead 
with a lump of grease, to which more or less of the sand or mud, or broken shells, as the case might be, adhered, and was brought to the surface. But, however well adapted such an apparatus might be for rough nautical purposes, scientific accuracy could not be expected from 5 the armed lead, and to remedy its defects (especially when applied to sounding in great depths) Lieut. Brooke, of the American Navy, some years ago invented a most ingenious machine, by which a considerable portion of the superficial layer of the sea-bottom can be scooped out and io brought up, from any depth to which the lead descends.

In 1853 , Lieut. Brooke obtained mud from the bottom of the North Atlantic, between Newfoundland and the Azores, at a depth of more than 10,000 feet, or two miles, by the help of this sounding apparatus. The 15 specimens were sent for examination to Ehrenberg of Berlin, and to Bailey of West Point, and those able microscopists found that this deep-sea mud was almost entirely composed of the skeletons of living organisms-the greater proportion of these being just like the Globigerine already 20 known to occur in the chalk.

Thus far, the work had been carried on simply in the interests of science, but Lieut. Brooke's method of sounding acquired a high commercial value, when the enterprise of laying down the telegraph-cable between this 25 country and the United States was undertaken. For it became a matter of immense importance to know, not only the depth of the sea over the whole line along which the cable was to be laid, but the exact nature of the bottom, so as to guard against chances of cutting or fraying the 30 strands of that costly rope. The Admiralty consequently ordered Captain Dayman, an old friend and shipmate of mine, to ascertain the depth over the whole line of the cable, and to bring back specimens of the bottom. In former 
days, such a command as this might have sounded very much like one of the impossible things which the young prince in the fairy tales is ordered to do before he can obtain the hand of the princess. However, in the months 5 of June and July 1857, my friend performed the task assigned to him with great expedition and precision, without, so far as I know, having met with any reward of that kind. The specimens of Atlantic mud which he procured were sent to me to be examined and reported upon.*

Io The result of all these operations is, that we know the contours and the nature of the surface-soil covered by the North Atlantic, for a distance of 1,700 miles from east to west, as well as we know that of any part of the dry land.

I5 It is a prodigious plain-one of the widest and most even plains in the world. If the sea were drained off, you might drive a wagon all the way from Valentia, on the west coast of Ireland, to Trinity Bay, in Newfoundland. And, except upon one sharp incline about 200 20 miles from Valentia, I am not quite sure that it would even be necessary to put the skid on, so gentle are the ascents and descents upon that long route. From Valentia the road would lie down-hill for about 200 miles to the point at which the bottom is now covered by 1,700 25 fathoms of sea-water. Then would come the central plain, more than a thousand miles wide, the inequalities of the surface of which would be hardly perceptible, though the depth of water upon it now varies from 10,000 to 15,000

* See Appendix to Captain Dayman's Deep-sea Soundings in 30 the North Atlantic Ocean, between Ireland and Newfoundland, made in H.M.S. "Cyclops." Published by order of the Lords Commissioners of the Admiralty, 1858. They have since formed the subject of an elaborate Memoir by Messrs. Parker and Jones, published in the Philosophical Transactions for $\mathbf{1 8 6 5}$. 
feet; and there are places in which Mont Blanc might be sunk without showing its peak above water. Beyond this, the ascent on the American side commences, and gradually leads, for about 300 miles, to the Newfoundland shore.

Almost the whole of the bottom of this central plain 5 (which extends for many hundred miles in a north and south direction) is covered by a fine mud, which, when brought to the surface, dries into a grayish-white friable substance. You can write with this on a blackboard, if you are so inclined; and, to the eye, it is quite like very to soft, grayish chalk. Examined chemically, it proves to be composed almost wholly of carbonate of lime; and if you make a section of it, in the same way as that of the piece of chalk was made, and view it with the microscope, it presents innumerable Globigerince embedded in a granu- I5 lar matrix.

Thus this deep-sea mud is substantially chalk. I say substantially, because there are a good many minor differences; but as these have no bearing on the question immediately before us, - which is the nature of the Globi- 20 gerince of the chalk,-it is unnecessary to speak of them.

Globigerince of every size, from the smallest to the largest, are associated together in the Atlantic mud, and the chambers of many are filled by a soft animal matter. This soft substance is, in fact, the remains of the creature 25 to which the Globigerina shell, or rather skeleton, owes its existence-and which is an animal of the simplest imaginable description. It is, in fact, a mere particle of living jelly, without defined parts of any kind-without a mouth, nerves, muscles, or distinct organs, and only 30 manifesting its vitality to ordinary observation by thrusting out and retracting from all parts of its surface, long filamentous processes, which serve for arms and legs. Yet this amorphous particle, devoid of everything which, 
in the higher animals, we call organs, is capable of feeding, growing, and multiplying; of separating from the ocean the small proportion of carbonate of lime which is dissolved in sea-water; and of building up that substance 5 into a skeleton for itself, according to a pattern which can be imitated by no other known agency.

The notion that animals can live and flourish in the sea, at the vast depths from which apparently living Globigerince have been brought up, does not agree very Io well with our usual conceptions respecting the conditions of animal life; and it is not so absolutely impossible as it might at first sight appear to be, that the Globigerine of the Atlantic sea-bottom do not live and die where they are found.

I5 As I have mentioned, the soundings from the great Atlantic plain are almost entirely made up of Globigerina, with the granules which have been mentioned, and some few other calcareous shells; but a small percentage of the chalky mud--perhaps at most some five 20 per cent. of it-is of a different nature, and consists of shells and skeletons composed of silex, or pure flint. These silicious bodies belong partly to the lowly vegetable organisms which are called Diatomacea, and partly to the minute, and extremely simple, animals, termed Radiolaria. 25 It is quite certain that these creatures do not live at the bottom of the ocean, but at its surface-where they may be obtained in prodigious numbers by the use of a properly constructed net. Hence it follows that these silicious organisms, though they are not heavier than the lightest 30 dust, must have fallen, in some cases through fifteen thousand feet of water, before they reached their final restingplace on the ocean floor. And, considering how large a surface these bodies expose in proportion to their weight, it is probable that they occupy a great length of time 


\section{On a Piece of Chalk}

in making their burial journey from the surface of the Atlantic to the bottom.

But if the Radiolaria and Diatoms are thus rained upon the bottom of the sea, from the superficial layer of its waters in which they pass their lives, it is ob- 5 viously possible that the Globigerina may be similarly derived; and if they were so, it would be much more easy to understand how they obtain their supply of food than it is at present. Nevertheless, the positive and negative evidence all points the other way. The skeletons io of the full-grown, deep-sea Globigerina are so remarkably solid and heavy in proportion to their surface as to seem little fitted for floating; and, as a matter of fact, they are not to be found along with the Diatoms and Radiolaria, in the uppermost stratum of the open ocean. I5

It has been observed, again, that the abundance of Globigerina, in proportion to other organisms, of like kind, increases with the depth of the sea; and that deep-water Globigerine are larger than those which live in shallower parts of the sea; and such facts negative 20 the supposition that these organisms have been swept by currents from the shallows into the deeps of the Atlantic.

It therefore seems to be hardly doubtful that these wonderful creatures live and die at the depths in which they are found.*

However, the important points for us are, that the living Globigerina are exclusively marine animals, the skeletons of which abound at the bottom of deep seas;

* During the cruise of H.M.S. Bulldog, commanded by Sir Leopold M'Clintock, in 1860 , living star-fish were brought up, 30 clinging to the lowest part of the sounding-line, from a depth of r,260 fathoms, midway between Cape Farewell, in Greenland, and the Rockall banks. Dr. Wallich ascertained that the seabottom at this point consisted of the ordinary Globigerina ooze, 
and that there is not a shadow of reason for believing that the habits of the Globigerince of the chalk differed from those of the existing species. But if this be true, there is no escaping the conclusion that the chalk itself 5 is the dried mud of an ancient deep sea.

In working over the soundings collected by Captain Dayman, I was surprised to find that many of what I have called the "granules" of that mud, were not, as one might have been tempted to think at first, the mere ro powder and waste of Globigerine, but that they had a definite form and size. I termed these bodies "coccoliths," and doubted their organic nature. Dr. Wallich verified my observation, and added the interesting discovery that, not unfrequently, bodies similar to these 15 "coccoliths" were aggregated together into spheroids, which he termed "coccospheres." So far as we know, these bodies, the nature of which is extremely puzzling and problematical, were peculiar to the Atlantic soundings.

But, a few years ago, Mr. Sorby, in making a careful 20 examination of the chalk by means of thin sections and otherwise, observed, as Ehrenberg had done before him, that much of its granular basis possesses a definite form. Comparing these formed particles with those in the Atlantic soundings, he found the two to be identical; and 25 thus proved that the chalk, like the soundings, contains these mysterious coccoliths and coccospheres. Here was a further and a most interesting confirmation, from in-

and that the stomachs of the star-fishes were full of Globigerince. This discovery removes all objections to the existence 30 of living Globigerince at great depths, which are based upon the supposed difficulty of maintaining animal life under such conditions; and it throws the burden of proof upon those who object to the supposition that the Globigerince live and die where they are found. 
ternal evidence, of the essential identity of the chalk with modern deep-sea mud. Globigerine, coccoliths, and coccospheres are found as the chief constituents of both, and testify to the general similarity of the conditions under which both have been formed.*

The evidence furnished by the hewing, facing, and superposition of the stones of the pyramids, that these structures were built by men, has no greater weight than the evidence that the chalk was built by Globigerina; and the belief that those ancient pyramid-builders were terrestrial ro and air-breathing creatures like themselves, is not better based than the conviction that the chalk-makers lived in the sea.

But as our belief in the building of the pyramids by men is not only grounded on the internal evidence afforded 15 by these structures, but gathers strength from multitudinous collateral proofs, and is clinched by the total absence of any reason for a contrary belief; so the evidence drawn from the Globerigine that the chalk is an ancient sea-bottom, is fortified by innumerable inde- 20 pendent lines of evidence; and our belief in the truth of the conclusion to which all positive testimony tends, receives the like negative justification from the fact that no other hypothesis has a shadow of foundation.

It may be worth while briefly to consider a few of 25 these collateral proofs that the chalk was deposited at the bottom of the sea.

The great mass of the chalk is composed, as we have seen, of the skeletons of Globigerina, and other simple

*I have recently traced out the development of the "cocco- 30 liths" from a diameter of $\frac{1}{7000}$ th of an inch up to their largest size (which is about $\frac{1}{1600} \mathrm{th}$ ), and no longer doubt that they are produced by independent organisms, which, like the Globigerine, live and die at the bottom of the sea. 
organisms, imbedded in granular matter. Here and there, however, this hardened mud of the ancient sea reveals the remains of higher animals which have lived and died, and left their hard parts in the mud, just as the oysters 5 die and leave their shells behind them, in the mud of the present seas.

There are, at the present day, certain groups of animals which are never found in fresh waters, being unable to live anywhere but in the sea. Such are the corals; those Io corallines which are called Polyzoa; those creatures which fabricate the lamp-shells, and are called Brachiopoda; the pearly Nautilus, and all animals allied to it; and all the forms of sea-urchins and star-fishes.

Not only are all these creatures confined to salt water 15 at the present day; but, so far as our records of the past go, the conditions of their existence have been the same: hence, their occurrence in any deposit is as strong evidence as can be obtained, that that deposit was formed in the sea. Now the remains of animals of all the kinds 20 which have been enumerated, occur in the chalk, in greater or less abundance; while not one of those forms of shellfish which are characteristic of fresh water has yet been observed in it.

When we consider that the remains of more than three 25 thousand distinct species of aquatic animals have been discovered among the fossils of the chalk, that the great majority of them are of such forms as are now met with only in the sea, and that there is no reason to believe that any one of them inhabited fresh water-the collateral 30 evidence that the chalk represents an ancient sea-bottom acquires as great force as the proof derived from the nature of the chalk itself. I think you will now allow that I did not overstate my case when I asserted that we have as strong grounds for believing that all the vast 
area of dry land, at present occupied by the chalk, was once at the bottom of the sea, as we have for any matter of history whatever; while there is no justification for any other belief.

No less certain it is that the time during which the $\mathbf{5}$ countries we now call south-east England, France, Germany, Poland, Russia, Egypt, Arabia, Syria, were more or less completely covered by a deep sea, was of considerable duration.

We have already seen that the chalk is, in places, ro more than a thousand feet thick. I think you will agree with me, that it must have taken some time for the skeletons of animalcules of a hundredth of an inch in diameter to heap up such a mass as that. I have said that throughout the thickness of the chalk the remains of other ani- 15 mals are scattered. These remains are often in the most exquisite state of preservation. The valves of the shellfishes are commonly adherent; the long spines of some of the sea-urchins, which would be detached by the smallest jar, often remain in their places. In a word, it is certain 20 that these animals have lived and died when the place which they now occupy was the surface of as much of the chalk as had then been deposited; and that each has been covered up by the layer of Globigerina mud, upon which the creatures imbedded a little higher up have, in like 25 manner, lived and died. But some of these remains prove the existence of reptiles of vast size in the chalk sea. These lived their time, and had their ancestors and descendants, which assuredly implies time, reptiles being of slow growth.

There is more curious evidence, again, that the process of covering up, or, in other words, the deposit of Globigerina skeletons, did not go on very fast. It is demonstrable that an animal of the cretaceous sea might die, 
that its skeleton might lie uncovered upon the sea-bottom long enough to lose all its outward coverings and appendages by putrefaction; and that, after this had happened, another animal might attach itself to the dead and naked 5 skeleton, might grow to maturity, and might itself die before the calcareous mud had buried the whole.

Cases of this kind are admirably described by Sir Charles Lyell. He speaks of the frequency with which geologists find in the chalk a fossilized sea-urchin, to Io which is attached the lower valve of a Crania. This is a kind of shell-fish, with a shell composed of two pieces, of which, as in the oyster, one is fixed and the other free.

"The upper valve is almost invariably wanting, though I5 occasionally found in a perfect state of preservation in the white chalk at some distance. In this case, we see clearly that the sea-urchin first lived from youth to age, then died and lost its spines, which were carried away. Then the young Crania adhered to the bared shell, grew 20 and perished in its turn; after which, the upper valve was separated from the lower, before the Echinus became enveloped in chalky mud." *

A specimen in the Museum of Practical Geology, in London, still further prolongs the period which must have 25 elapsed between the death of the sea-urchin, and its burial by the Globigerina. For the outward face of the valve of a Crania, which is attached to a sea-urchin (Micraster), is itself overrun by an incrusting coralline, which spreads thence over more or less of the surface of the sea-urchin. 30 It follows that, after the upper valve of the Crania fell off, the surface of the attached valve must have remained exposed long enough to allow of the growth of the

* Elements of Geology, by Sir Charles Lyell, Bart., F.R.S., p. 23. 
whole coralline, since corallines do not live imbedded in mud.

The progress of knowledge may, one day, enable us to deduce from such facts as these the maximum rate at which the chalk can have accumulated, and thus to 5 arrive at the minimum duration of the chalk period. Suppose that the valve of the Crania upon which a coralline has fixed itself in the way just described, is so attached to the sea-urchin that no part of it is more than an inch above the face upon which the sea-urchin rests. Io Then, as the coralline could not have fixed itself, if the Crania had been covered up with chalk mud, and could not have lived had itself been so covered, it follows, that an inch of chalk mud could not have accumulated within the time between the death and decay of the soft 15 parts of the sea-urchin and the growth of the coralline to the full size which it has attained. If the decay of the soft parts of the sea-urchin; the attachment, growth to maturity, and decay of the Crania; and the subsequent attachment and growth of the coralline, took a year 20 (which is a low estimate enough), the accumulation of the inch of chalk must have taken more than a year: and the deposit of a thousand feet of chalk must, consequently, have taken more than twelve thousand years.

The foundation of all this calculation is, of course, a knowledge of the length of time the Crania and the coralline needed to attain their full size; and, on this head, precise knowledge is at present wanting. But there are circumstances which tend to show, that nothing 30 like an inch of chalk has accumulated during the life of a Crania; and, on any probable estimate of the length of that life, the chalk period must have had a much longer duration than that thus roughly assigned to it. 
Thus, not only is it certain that the chalk is the mud of an ancient sea-bottom; but it is no less certain, that the chalk sea existed during an extremely long period, though we may not be prepared to give a precise estimate of the 5 length of that period in years. The relative duration is clear, though the absolute duration may not be definable. The attempt to affix any precise date to the period at which the chalk sea began, or ended, its existence, is baffled by difficulties of the same kind. But the relaIo tive age of the cretaceous epoch may be determined with as great ease and certainty as the long duration of that epoch.

You will have heard of the interesting discoveries recently made, in various parts of Western Europe, of flint 15 implements, obviously worked into shape by human hands, under circumstances which show conclusively that man is a very ancient denizen of these regions.

It has been proved that the old populations of Europe, whose existence has been revealed to us in this way, con20 sisted of savages, such as the Esquimaux are now; that, in the country which is now France, they hunted the reindeer, and were familiar with the ways of the mammoth and the bison. The physical geography of France was in those days different from what it is now-the river 25 Somme, for instance, having cut its bed a hundred feet deeper between that time and this; and, it is probable, that the climate was more like that of Canada or Siberia, than that of Western Europe.

The existence of these people is forgotten even in the 30 traditions of the oldest historical nations. The name and fame of them had utterly vanished until a few years back; and the amount of physical change which has been effected since their day, renders it more than probable that, venerable as are some of the historical nations, the 
workers of the chipped flints of Hoxne or of Amiens are to them, as they are to us, in point of antiquity.

But, if we assign to these hoar relics of long-vanished generations of men the greatest age that can possibly be claimed for them, they are not older than the drift, or 5 boulder clay, which, in comparison with the chalk, is but a very juvenile deposit. You need go no further that your own sea-board for evidence of this fact. At one of the most charming spots on the coast of Norfolk, Cromer, you will see the boulder clay forming a vast io mass, which lies upon the chalk, and must consequently have come into existence after it. Huge boulders of chalk are, in fact, included in the clay, and have evidently been brought to the position they now occupy, by the same agency as that which has planted blocks of 15 syenite from Norway side by side with them.

The chalk, then, is certainly older than the boulder clay. If you ask how much, I will again take you no further than the same spot upon your own coasts for evidence. I have spoken of the boulder clay and drift,2o as resting upon the chalk. That is not strictly true. Interposed between the chalk and the drift is a comparatively insignificant layer, containing vegetable matter. But that layer tells a wonderful history. It is full of stumps of trees standing as they grew. Fir-trees are 25 there with their cones, and hazel-bushes with their nuts; there stand the stools of oak and yew trees, beeches and alders. Hence this stratum is appropriately called the "forest-bed."

It is obvious that the chalk must have been upheaved 30 and converted into dry land, before the timber trees could grow upon it. As the bolls of some of these trees are from two to three feet in diameter, it is no less clear that the dry land thus formed remained in the same 
condition for long ages. And not only do the remains of stately oaks and well-grown firs testify to the duration of this condition of things, but additional evidence to the same effect is afforded by the abundant remains of 5 elephants, rhinoceroses, hippopotamuses, and other great wild beasts, which it has yielded to the zealous search of such men as the Rev. Mr. Gunn.

When you look at such a collection as he has formed, and bethink you that these elephantine bones did veritably Io carry their owners about, and these great grinders crunch, in the dark woods of which the forest-bed is now the only trace, it is impossible not to feel that they are as good evidence of the lapse of time as the annual rings of the tree-stumps.

15 Thus there is a writing upon the wall of cliffs at Cromer, and whoso runs may read it. It tells us, with an authority which cannot be impeached, that the ancient sea-bed of the chalk sea was raised up, and remained dry land, until it was covered with forest, stocked with the 20 great game whose spoils have rejoiced your geologists. How long it remained in that condition cannot be said; but "the whirligig of time brought its revenges" in those days as in these. That dry land, with the bones and teeth of generations of long-lived elephants, hidden away 25 among the gnarled roots and dry leaves of its ancient trees, sank gradually to the bottom of the icy sea, which covered it with huge masses of drift and boulder clay. Seabeasts, such as the walrus, now restricted to the extreme north, paddled about where birds had twittered among 30 the topmost twigs of the fir-trees. How long this state of things endured we know not, but at length it came to an end. The upheaved glacial mud hardened into the soil of modern Norfolk. Forests grew once more, the wolf and the beaver replaced the reindeer and the elephant; 
and at length what we call the history of England dawned.

Thus you have, within the limits of your own county, proof that the chalk can justly claim a very much greater antiquity than even the oldest physical traces of mankind. 5 But we may go further and demonstrate, by evidence of the same authority as that which testifies to the existence of the father of men, that the chalk is vastly older than Adam himself.

The Book of Genesis informs us that Adam, immedi- ro ately upon his creation, and before the appearance of Eve, was placed in the Garden of Eden. The problem of the geographical position of Eden has greatly vexed the spirits of the learned in such matters, but there is one point respecting which, so far as I know, no commentator 15 has ever raised a doubt. This is, that of the four rivers which are said to run out of it, Euphrates and Hiddekel are identical with the rivers now known by the names of Euphrates and Tigris.

But the whole country in which these mighty rivers 20 take their origin, and through which they run, is composed of rocks which are either of the same age as the chalk, or of later date. So that the chalk must not only have been formed, but, after its formation, the time required for the deposit of these later rocks, and for their upheaval 25 into dry land, must have elapsed, before the smallest brook which feeds the swift stream of "the great river, the river of Babylon," began to flow.

Thus, evidence which cannot be rebutted, and which need not be strengthened, though if time permitted I 30 might indefinitely increase its quantity, compels you to believe that the earth, from the time of the chalk to the present day, has been the theater of a series of changes as 
vast in their amount, as they were slow in their progress. The area on which we stand has been first sea and then land, for at least four alternations; and has remained in each of these conditions for a period of great length.

5 Nor have these wonderful metamorphoses of sea into land, and of land into sea, been confined to one corner of England. During the chalk period, or "cretaceous epoch," not one of the present great physical features of the globe was in existence. Our great mountain ranges, to Pyrenees, Alps, Himalayas, Andes, have all been upheaved since the chalk was deposited, and the cretaceous sea flowed over the sites of Sinai and Ararat.

All this is certain, because rocks of cretaceous, or still later, date have shared in the elevatory movements which 15 gave rise to these mountain chains; and may be found perched up, in some cases, many thousand feet high upon their flanks. And evidence of equal cogency demonstrates that, though, in Norfolk, the forest-bed rests directly upon the chalk, yet it does so, not because the period at which 20 the forest grew immediately followed that at which the chalk was formed, but because an immense lapse of time, represented elsewhere by thousands of feet of rock, is not indicated at Cromer.

I must ask you to believe that there is no less con25 clusive proof that a still more prolonged succession of similar changes occurred, before the chalk was deposited. Nor have we any reason to think that the first term in the series of these changes is known. The oldest seabeds preserved to us are sands, and mud, and pebbles, 30 the wear and tear of rocks which were formed in still older oceans.

But, great as is the magnitude of these physical changes of the world, they have been accompanied by a no less striking series of modifications in its living inhabitants. 
All the great classes of animals, beasts of the field, fowls of the air, creeping things, and things which dwell in the waters, flourished upon the globe long ages before the chalk was deposited. Very few, however, if any, of these ancient forms of animal life were identical with 5 those which now live. Certainly not one of the higher animals was of the same species as any of those now in existence. The beasts of the field, in the days before the chalk, were not our beasts of the field, nor the fowls of the air such as those which the eye of men has seen io flying, unless his antiquity dates infinitely further back than we at present surmise. If we could be carried back into those times, we should be as one suddenly set down in Australia before it was colonized. We should see mammals, birds, reptiles, fishes, insects, snails, and I5 the like, clearly recognizable as such, and yet not one of them would be just the same as those with which we are familiar, and many would be extremely different.

From that time to the present, the population of the world has undergone slow and gradual, but incessant, 20 changes. There has been no grand catastrophe-no destroyer has swept away the forms of life of one period, and replaced them by a totally new creation; but one species has vanished and another has taken its place; creatures of one type of structure have diminished, those 25 of another have increased, as time has passed on. And thus, while the differences between the living creatures of the time before the chalk and those of the present day appear startling, if placed side by side, we are led from one to the other by the most gradual progress, if we follow 30 the course of Nature through the whole series of those relics of her operations which she has left behind.

And it is by the population of the chalk sea that the ancient and the modern inhabitants of the world are 
most completely connected. The groups which are dying out flourish, side by side, with the groups which are now the dominant forms of life.

Thus the chalk contains remains of those strange 5 flying and swimming reptiles, the pterodactyl, the ichthyosaurus, and the plesiosaurus, which are found in no later deposits, but abounded in preceding ages. The chambered shells called ammonites and belemnites, which are so characteristic of the period preceding the cretaceous, Io in like manner die with it.

But, amongst these fading remainders of a previous state of things, are some very modern forms of life, looking like Yankee peddlers among a tribe of Red Indians. Crocodiles of modern type appear; bony fishes, I5 many of them very similar to existing species, almost supplant the forms of fish which predominate in more ancient seas; and many kinds of living shell-fish first become known to us in the chalk. The vegetation acquires a modern aspect. A few living animals are not even 20 distinguishable as species from those which existed at that remote epoch. The Globigerina of the present day, for example, is not different specifically from that of the chalk; and the same may be said of many other Foraminifera. I think it probable that critical and unpreju25 diced examination will show that more than one species of much higher animals have had a similar longevity; but the only example which I can at present give confidently is the snake's-head lamp-shell (Terebratulina caput serpentis), which lives in our English seas and 30 abounded (as Terebratulina striata of authors) in the chalk.

The longest line of human ancestry must hide its diminished head before the pedigree of this insignificant shellfish. We Englishmen are proud to have an ancestor who 


\section{On a Piece of Chalk}

was present at the Battle of Hastings. The ancestors of Terebratulina caput serpentis may have been present at a battle of Ichthyosauria in that part of the sea which, when the chalk was forming, flowed over the site of Hastings. While all around has changed, this Terebratu- 5 lina has peacefully propagated its species from generation to generation, and stands to this day, as a living testimony to the continuity of the present with the past history of the globe.

Up to this moment I have stated, so far as I know, Io nothing but well-authenticated facts, and the immediate conclusions which they force upon the mind.

But the mind is so constituted that it does not willingly rest in facts and immediate causes, but seeks always after a knowledge of the remoter links in the chain of 15 causation.

Taking the many changes of any given spot of the earth's surface, from sea to land and from land to sea, as an established fact, we cannot refrain from asking ourselves how these changes have occurred. And when we 20 have explained them-as they must be explained-by the alternate slow movements of elevation and depression which have affected the crust of the earth, we go still further back, and ask, Why these movements?

I am not certain that any one can give you a satis- 25 factory answer to that question. Assuredly I cannot. All that can be said, for certain, is, that such movements are part of the ordinary course of nature, inasmuch as they are going on at the present time. Direct proof may be given, that some parts of the land of the northern 30 hemisphere are at this moment insensibly rising and others insensibly sinking; and there is indirect, but perfectly satisfactory, proof, that an enormous area now covered 
by the Pacific has been deepened thousands of feet, since the present inhabitants of that sea came into existence.

Thus there is not a shadow of a reason for believing that the physical changes of the globe, in past times, 5 have been effected by other than natural causes.

Is there any more reason for believing that the concomitant modifications in the forms of the living inhabitants of the globe have been brought about in other ways?

Before attempting to answer this question, let us try to to form a distinct mental picture of what has happened, in some special case.

The crocodiles are animals which, as a group, have a very vast antiquity. They abounded ages before the chalk was deposited; they throng the rivers in warm I5 climates, at the present day. There is a difference in the form of the joints of the backbone, and in some minor particulars, between the crocodiles of the present epoch and those which lived before the chalk; but, in the cretaceous epoch, as I have already mentioned, the 20 crocodiles had assumed the modern type of structure. Notwithstanding this, the crocodiles of the chalk are not identically the same as those which lived in the times called "older tertiary," which succeeded the cretaceous epoch; and the crocodiles of the older tertiaries are not 25 identical with those of the newer tertiaries, nor are these identical with existing forms. I leave open the question whether particular species may have lived on from epoch to epoch. But each epoch has had its peculiar crocodiles; though all, since the chalk, have belonged to the modern 30 type, and differ simply in their proportions, and in such structural particulars as are discernible only to trained eyes.

How is the existence of this long succession of different species of crocodiles to be accounted for? 
Only two suppositions seem to be open to us-Either each species of crocodile has been specially created, or it has arisen out of some pre-existing form by the operation of natural causes.

Choose your hypothesis; I have chosen mine. I can 5 find no warranty for believing in the distinct creation of a score of successive species of crocodiles in the course of countless ages of time. Science gives no countenance to such a wild fancy; nor can even the perverse ingenuity of a commentator pretend to discover this sense, in the ro simple words in which the writer of Genesis records the proceedings of the fifth and sixth days of the Creation.

On the other hand, I see no good reason for doubting the necessary alternative, that all these varied species 15 have been evolved from pre-existing crocodilian forms, by the operation of causes as completely a part of the common order of nature, as those which have effected the changes of the inorganic world.

Few will venture to affirm that the reasoning which 20 applies to crocodiles loses its force among other animals, or among plants. If one series of species has come into existence by the operation of natural causes, it seems folly to deny that all may have arisen in the same way.

A small beginning has led us to a great ending. If I 25 were to put the bit of chalk with which we started into the hot but obscure flame of burning hydrogen, it would presently shine like the sun. It seems to me that this physical metamorphosis is no false image of what has been the result of our subjecting it to a jet of fervent, 30 though nowise brilliant, thought to-night. It has become luminous, and its clear rays, penetrating the abyss of the remote past, have brought within our ken some stages 
of the evolution of the earth. And in the shifting "without haste, but without rest" of the land and sea, as in the endless variation of the forms assumed by living beings, we have observed nothing but the natural product of the 5 forces originally possessed by the substance of the universe. 


\section{ON SCIENCE AND ART IN RELATION TO EDUCATION}

\section{( 1882$)$}

When a man is honored by such a request as that which reached me from the authorities of your institution some time ago, I think the first thing that occurs to him is that which occurred to those who were bidden to the feast in the Gospel一to begin to make an excuse; and 5 probably all the excuses suggested on that famous occasion crop up in his mind one after the other, including his "having married a wife," as reasons for not doing what he is asked to do. But, in my own case, and on this particular occasion, there were other difficulties of a sort ro peculiar to the time, and more or less personal to myself; because I felt that, if I came amongst you, I should be expected, and, indeed, morally compelled, to speak upon the subject of Scientific Education. And then there arose in my mind the recollection of a fact, which probably no 15 one here but myself remembers; namely, that some fourteen years ago I was the guest of a citizen of yours, who bears the honored name of Rathbone, at a very charming and pleasant dinner given by the Philomathic Society; and I there and then, and in this very city, made a speech upon 20 the topic of Scientific Education. Under these circumstances, you see, one runs two dangers-the first, of repeating one's self, although I may fairly hope that everybody has forgotten the fact I have just now mentioned, except 
myself; and the second, and even greater difficulty, is the danger of saying something different from what one said before, because then, however forgotten your previous speech may be, somebody finds out its existence, and there 5 goes on that process so hateful to members of Parliament, which may be denoted by the term "Hansardization." Under these circumstances, I came to the conclusion that the best thing I could do was to take the bull by the horns, and to "Hansardize" myself-to put before you, in the Io briefest possible way, the three or four propositions which I endeavored to support on the occasion of the speech to which I have referred; and then to ask myself, supposing you were asking me, whether I had anything to retract, or to modify, in them, in virtue of the increased experience, I5 and, let us charitably hope, the increased wisdom of an added fourteen years.

Now, the points to which I directed particular attention on that occasion were these: in the first place, that instruction in physical science supplies information of a char20 acter of especial value, both in a practical and a speculative point of view-information which cannot be obtained otherwise; and, in the second place, that, as educational discipline, it supplies, in a better form than any other study can supply, exercise in a special form of logic, and a 25 peculiar method of testing the validity of our processes of inquiry. I said further, that, even at that time, a great and increasing attention was being paid to physical science in our schools and colleges, and that, most assuredly, such attention must go on growing and increasing, until educa30 tion in these matters occupied a very much larger share of the time which is given to teaching and training, than had been the case heretofore. And I threw all the strength of argumentation of which I was possessed into the support of these propositions. But I venture to remind you, 
also, of some other words I used at that time, and which I ask permission to read to you. They were these: "There are other forms of culture besides physical science, and I should be profoundly sorry to see the fact forgotten, or even to observe a tendency to starve or cripple literary or 5 æsthetic culture for the sake of science. Such a narrow view of the nature of education has nothing to do with my firm conclusion that a complete and thorough scientific culture ought to be introduced into all schools."

I say I desire, in commenting upon these various points, Io and judging them as fairly as I can by the light of increased experience, to particularly emphasize this last, because I am told, although I assuredly do not know it of my own knowledge-though I think if the fact were so I ought to know it, being tolerably well acquainted with 15 that which goes on in the scientific world, and which has gone on there for the last thirty years-that there is a kind of sect, or horde, of scientific Goths and Vandals, who think it would be proper and desirable to sweep away all other forms of culture and instruction, except 20 those in physical science, and to make them the universal and exclusive, or, at any rate, the dominant training of the human mind of the future generation. This is not my view-I do not believe that it is anybody's view-but it is attributed to those who, like myself, advocate scientific 25 education. I therefore dwell strongly upon the point, and I beg you to believe that the words I have just now read were by no means intended by me as a sop to the Cerberus of culture. I have not been in the habit of offering sops to any kind of Cerberus; but it was an expression of pro- 30 found conviction on my own part-a conviction forced upon me not only by my mental constitution, but by the lessons of what is now becoming a somewhat long experience of varied conditions of life. 
I am not about to trouble you with my autobiography; the omens are hardly favorable, at present, for work of that kind. But I should like if I may do so without appearing, what I earnestly desire not to be, egotistical-I 5 should like to make it clear to you, that such notions as these, which are sometimes attributed to me, are, as I have said, inconsistent with my mental constitution, and still more inconsistent with the upshot of the teaching of my experience. For I can certainly claim for myself that sort Io of mental temperament which can say that nothing human comes amiss to it. I have never yet met with any branch of human knowledge which I have found unattractivewhich it would not have been pleasant to me to follow, so far as I could go; and I have yet to meet with any form 15 of art in which it has not been possible for me to take as acute a pleasure as, I believe, it is possible for men to take.

And with respect to the circumstances of life, it so happens that it has been my fate to know many lands and 20 many climates, and to be familiar, by personal experience, with almost every form of society, from the uncivilized savage of Papua and Australia and the civilized savages of the slums and dens of the poverty-stricken parts of great cities, to those who, perhaps, are occasionally the some25 what over-civilized members of our upper ten thousand. And I have never found, in any of these conditions of life, a deficiency of something which was attractive. Savagery has its pleasures, I assure you, as well as civilization, and I may even venture to confess-if you will not let 30 a whisper of the matter get back to London, where I am known-I am even fain to confess, that sometimes in the din and throng of what is called "a brilliant reception" the vision crosses my mind of waking up from the soft plank which has afforded me satisfactory sleep during the 
hours of the night, in the bright dawn of a tropical morning, when my comrades were yet asleep, when every sound was hushed, except the little lap-lap of the ripples against the sides of the boat, and the distant twitter of the sea-bird on the reef. And when that vision crosses my 5 mind, I am free to confess I desire to be back in the boat again. So that, if I share with those strange persons to whose asserted, but still hypothetical existence I have referred, the want of appreciation of forms of culture other than the pursuit of physical science, all I can say is, that 10 it is, in spite of my constitution, and in spite of my experience, that such should be my fate.

But now let me turn to another point, or rather to two other points, with which I propose to occupy myself. How far does the experience of the last fourteen years justify $\mathbf{I 5}$ the estimate which I ventured to put forward of the value of scientific culture, and of the share-the increasing share -which it must take in ordinary education? Happily, in respect to that matter, you need not rely upon my testimony. In the last half-dozen numbers of the Journal of 20 Education, you will find a series of very interesting and remarkable papers, by gentlemen who are practically engaged in the business of education in our great public and other schools, telling us what is doing in these schools, and what is their experience of the results of scientific 25 education there, so far as it has gone. I am not going to trouble you with an abstract of those papers, which are well worth your study in their fullness and completeness, but I have copied out one remarkable passage, because it seems to me so entirely to bear out what I have formerly 30 ventured to say about the value of science, both as to its subject-matter and as to the discipline which the learning of science involves. It is from a paper by Mr. Worthington-one of the masters at Clifton, the reputation of which 
school you know well, and at the head of which is an old friend of mine, the Rev. Mr. Wilson-to whom much credit is due for being one of the first, as I can say from my own knowledge, to take up this question and work 5 it into practical shape. What Mr. Worthington says is this:

"It is not easy to exaggerate the importance of the information imparted by certain branches of science; it modifies the whole criticism of life made in maturer Io years. The study has often, on a mass of boys, a certain influence which, I think, was hardly anticipated, and to which a good deal of value must be attached-an influence as much moral as intellectual, which is shown in the increased and increasing respect for precision of statement, 15 and for that form of veracity which consists in the acknowledgment of difficulties. It produces a real effect to find that Nature cannot be imposed upon, and the attention given to experimental lectures, at first superficial and curious only, soon becomes minute, serious, and practical."

20 Ladies and gentlemen, I could not have chosen better words to express-in fact, I have, in other words, expressed the same conviction in former days-what the influence of scientific teaching, if properly carried out, must be.

25 But now comes the question of properly carrying it out, because, when $I$ hear the value of school teaching in physical science disputed, my first impulse is to ask the disputer, "What have you known about it?" and he generally tells me some lamentable case of failure. Then 30 I ask, "What are the circumstances of the case, and how was the teaching carried out?" I remember, some few years ago, hearing of the head master of a large school, who had expressed great dissatisfaction with the adoption 
of the teaching of physical science-and that after experiment. But the experiment consisted in this-in asking one of the junior masters in the school to get up science, in order to teach it; and the young gentleman went away for a year and got up science and taught it. Well, I have 5 no doubt that the result was as disappointing as the head master said it was, and I have no doubt that it ought to have been as disappointing, and far more disappointing too; for, if this kind of instruction is to be of any good at all, if it is not to be less than no good, if it to is to take the place of that which is already of some good, then there are several points which must be attended to.

And the first of these is the proper selection of topics, the second is practical teaching, the third is practical teachers, and the fourth is sufficiency of time. If these four 15 points are not carefully attended to by anybody who undertakes the teaching of physical science in schools, my advice to him is, to let it alone. I will not dwell at any length upon the first point, because there is a general consensus of opinion as to the nature of the topics which 20 should be chosen. The second point-practical teachingis one of great importance, because it requires more capital to set it agoing, demands more time, and, last, but by no means least, it requires much more personal exertion and trouble on the part of those professing to teach, 25 than is the case with other kinds of instruction.

When I accepted the invitation to be here this evening, your secretary was good enough to send me the addresses which have been given by distinguished persons who have previously occupied this chair. I don't know whether he 30 had a malicious desire to alarm me; but, however that may be, I read the addresses, and derived the greatest pleasure and profit from some of them, and from none more than from the one given by the great historian, Mr. Freeman, 
which delighted me most of all; and, if I had not been ashamed of plagiarizing, and if I had not been sure of being found out, I should have been glad to have copied very much of what Mr. Freeman said, simply putting in 5 the word science for history. There was one notable passage: "The difference between good and bad teaching mainly consists in this, whether the words used are really clothed with a meaning or not." And Mr. Freeman gives a remarkable example of this. He says, when a little girl Io was asked where Turkey was, she answered that it was in the yard with the other fowls, and that showed she had a definite idea connected with the word Turkey, and was, so far, worthy of praise. I quite agree with that commendation; but what a curious thing it is that one should now I5 find it necessary to urge that this is the be-all and end-all of scientific instruction-the sine quâ non, the absolutely necessary condition, - and yet that it was insisted upon more than two hundred years ago by one of the greatest men science ever possessed in this country, William Har20 vey. Harvey wrote, or at least published, only two small books, one of which is the well-known treatise on the circulation of the blood. The other, the Exercitationes de Generatione, is less known, but not less remarkable. And not the least valuable part of it is the preface, in which 25 there occurs this passage: "Those who, reading the words of authors, do not form sensible images of the things referred to, obtain no true ideas, but conceive false imaginations and inane phantasms." You see, William Harvey's words are just the same in substance as those 30 of Mr. Freeman, only they happen to be rather more than two centuries older. So that what I am now saying has its application elsewhere than in science; but assuredly in science the condition of knowing, of your own knowledge, things which you talk about, is absolutely imperative. 
I remember, in my youth, there were detestable books which ought to have been burned by the hands of the common hangman, for they contained questions and answers to be learned by heart, of this sort, "What is a horse? The horse is termed Equus caballus; belongs to the 5 class Mammalia; order, Pachydermata; family, Solidungula." Was any human being wiser for learning that magic formula? Was he not more foolish, inasmuch as he was deluded into taking words for knowledge? It is that kind of teaching that one wants to get rid of, and so banished out of science. Make it as little as you like, but, unless that which is taught is based on actual observation and familiarity with facts, it is better left alone.

There are a great many people who imagine that elementary teaching might be properly carried out by teachers 15 provided with only elementary knowledge. Let me assure you that that is the profoundest mistake in the world. There is nothing so difficult to do as to write a good elementary book, and there is nobody so hard to teach properly and well as people who know nothing about a 20 subject, and I will tell you why. If I address an audience of persons who are occupied in the same line of work as myself, I can assume that they know a vast deal, and that they can find out the blunders I make. If they don't it is their fault and not mine; but when I appear before 25 a body of people who know nothing about the matter, who take for gospel whatever I say, surely it becomes needful that I consider what I say, make sure that it will bear examination, and that I do not impose upon the credulity of those who have faith in me. In the second place, it 30 involves that difficult process of knowing what you know so well that you can talk about it as you can talk about your ordinary business. A man can always talk about his own business. He can always make it plain; but, if his 
knowledge is hearsay, he is afraid to go beyond what he has recollected, and put it before those that are ignorant in such a shape that they shall comprehend it. That is why, to be a good elementary teacher, to teach the ele5 ments of any subject, requires most careful consideration, if you are a master of the subject; and, if you are not a master of it, it is needful you should familiarize yourself with so much as you are called upon to teach-soak yourself in it, so to speak-until you know it as part of your Io daily life and daily knowledge, and then you will be able to teach anybody. That is what I mean by practical teachers, and, although the deficiency of such teachers is being remedied to a large extent, I think it is one which has long existed, and which has existed from no fault of those 15 who undertook to teach, but because, until the last score of years, it absolutely was not possible for any one in a great many branches of science, whatever his desire might be, to get instruction which would enable him to be a good teacher of elementary things. All that is being rapidly 20 altered, and I hope it will soon become a thing of the past.

The last point I have referred to is the question of the sufficiency of time. And here comes the rub. The teaching of science needs time, as any other subject; but it 25 needs more time proportionally than other subjects, for the amount of work obviously done, if the teaching is to be, as I have said, practical. Work done in a laboratory involves a good deal of expenditure of time without always an obvious result, because we do not see anything of that quiet 30 process of soaking the facts into the mind, which takes place through the organs of the senses. On this ground there must be ample time given to science teaching. What that amount of time should be is a point which I need not discuss now; in fact, it is a point which cannot 
be settled until one has made up one's mind about various other questions.

All, then, that I have to ask for, on behalf of the scientific people, if I may venture to speak for more than myself, is that you should put scientific teaching into what 5 statesmen call the condition of "the most favored nation"; that is to say, that it shall have as large a share of the time given to education as any other principal subject. You may say that that is a very vague statement, because the value of the allotment of time, under those circum- io stances, depends upon the number of principal subjects. It is $x$ the time, and an unknown quantity of principal subjects dividing that, and science taking shares with the rest. That shows that we cannot deal with this question fully until we have made up our minds as to what the 15 principal subjects of education ought to be.

I know quite well that launching myself into this discussion is a very dangerous operation; that it is a very large subject, and one which is difficult to deal with, however much I may trespass upon your patience in the time 20 allotted to me. But the discussion is so fundamental, it is so completely impossible to make up one's mind on these matters until one has settled the question, that I will even venture to make the experiment. A great lawyer-statesman and philosopher of a former age-I mean 25 Francis Bacon-said that truth came out of error much more rapidly than it came out of confusion. There is a wonderful truth in that saying. Next to being right in this world, the best of all things is to be clearly and definitely wrong, because you will come out somewhere. 30 If you go buzzing about between right and wrong, vibrating and fluctuating, you come out nowhere; but if you are absolutely and thoroughly and persistently wrong, you must, some of these days, have the extreme good fortune 
of knocking your head against a fact, and that sets you all straight again. So I will not trouble myself as to whether I may be right or wrong in what I am about to say, but at any rate $I$ hope to be clear and definite; 5 and then you will be able to judge for yourselves whether, in following out the train of thought I have to introduce, you knock your heads against facts or not.

I take it that the whole object of education is, in the first place, to train the faculties of the young in such a Io manner as to give their possessors the best chance of being happy and useful in their generation; and, in the second place, to furnish them with the most important portions of that immense capitalized experience of the human race which we call knowledge of various kinds. I am using the I5 term knowledge in its widest possible sense; and the question is, what subjects to select by training and discipline, in which the object I have just defined may be best attained.

I must call your attention further to this fact, that all 20 the subjects of our thoughts-all feelings and propositions (leaving aside our sensations as the mere materials and occasions of thinking and feeling), all our mental furniture - may be classified under one of two heads-as either within the province of the intellect, something that can be 25 put into propositions and affirmed or denied; or as within the province of feeling, or that which, before the name was defiled, was called the æsthetic side of our nature, and which can neither be proved nor disproved, but only felt and known.

30 According to the classification which I have put before you, then, the subjects of all knowledge are divisible into the two groups, matters of science and matters of art; for all things with which the reasoning faculty alone is occupied, come under the province of science; and in the broad- 
est sense, and not in the narrow and technical sense in which we are now accustomed to use the word art, all things feelable, all things which stir our emotions, come under the term of art, in the sense of the subject-matter of the æsthetic faculty. So that we are shut up to this- 5 that the business of education is, in the first place, to provide the young with the means and the habit of observation; and, secondly, to supply the subject-matter of knowledge either in the shape of science or of art, or of both combined.

Now, it is a very remarkable fact-but it is true of most things in this world-that there is hardly anything onesided, or of one nature; and it is not immediately obvious what of the things that interest us may be regarded as pure science, and what may be regarded as pure art. It may be 15 that there are some peculiarly constituted persons who, before they have advanced far into the depths of geometry, find artistic beauty about it; but, taking the generality of mankind, I think it may be said that, when they begin to learn mathematics, their whole souls are absorbed in trac- 20 ing the connection between the premises and the conclusion, and that to them geometry is pure science. So I think it may be said that mechanics and osteology are pure science. On the other hand, melody in music is pure art. You cannot reason about it; there is no proposition involved in it. 25 So, again, in the pictorial art, an arabesque, or a "harmony in gray," touches none but the æsthetic faculty. But a great mathematician, and even many persons who are not great mathematicians, will tell you that they derive immense pleasure from geometrical reasonings. Everybody 30 knows mathematicians speak of solutions and problems as "elegant," and they tell you that a certain mass of mystic symbols is "beautiful, quite lovely." Well, you do not see it. They do see it, because the intellectual process, the 
process of comprehending the reasons symbolized by these figures and these signs, confers upon them a sort of pleasure, such as an artist has in visual symmetry. Take a science of which I may speak with more confidence, and 5 which is the most attractive of those I am concerned with. It is what we call morphology, which consists in tracing out the unity in variety of the infinitely diversified structures of animals and plants. I cannot give you any example of a thorough æsthetic pleasure more intensely real than a Io pleasure of this kind-the pleasure which arises in one's mind when a whole mass of different structures run into one harmony as the expression of a central law. That is where the province of art overlays and embraces the province of intellect. And, if I may venture to express an I5 opinion on such a subject, the great majority of forms of art are not in a sense what I just now defined them to be - pure art; but they derive much of their quality from simultaneous and even unconscious excitement of the intellect.

20 When I was a boy, I was very fond of music, and I am so now; and it so happened that I had the opportunity of hearing much good music. Among other things, I had abundant opportunities of hearing that great old master, Sebastian Bach. I remember perfectly well-though I 25 knew nothing about music then, and, I may add, know nothing whatever about it now-the intense satisfaction and delight which I had in listening, by the hour together, to Bach's fugues. It is a pleasure which remains with me, I am glad to think; but, of late years, I have tried to find 30 out the why and wherefore, and it has often occurred to me that the pleasure derived from musical compositions of this kind is essentially of the same nature as that which is derived from pursuits which are commonly regarded as purely intellectual. I mean, that the source of pleasure is exactly 
the same as in most of my problems in morphology-that you have the theme in one of the old master's works followed out in all its endless variations, always appearing and always reminding you of unity in variety. So in painting; what is called "truth to nature" is the intellectual 5 element coming in, and truth to nature depends entirely upon the intellectual culture of the person to whom art is addressed. If you are in Australia, you may get credit for being a good artist-I mean among the natives-if you draw a kangaroo after a fashion. But, among men of to higher civilization, the intellectual knowledge we possess brings its criticism into our appreciation of works of art, and we are obliged to satisfy it, as well as the mere sense of beauty in color and in outline. And so, the higher the culture and information of those whom art addresses, the I5 more exact and precise must be what we call its "truth to nature."

If we turn to literature, the same thing is true, and you find works of literature which may be said to be pure art. A little song of Shakespeare or of Goethe is pure art; it is 20 exquisitely beautiful, although its intellectual content may be nothing. A series of pictures is made to pass before your mind by the meaning of words, and the effect is a melody of ideas. Nevertheless, the great mass of the literature we esteem is valued, not merely because of hav- 25 ing artistic form, but because of its-intellectual content; and the value is the higher the more precise, distinct, and true is that intellectual content. And, if you will let me for a moment speak of the very highest forms of literature, do we not regard them as highest simply because the 30 more we know the truer they seem, and the more competent we are to appreciate beauty the more beautiful they are? No man ever understands Shakespeare until he is old, though the youngest may admire him, the reason 
being that he satisfies the artistic instinct of the youngest and harmonizes with the ripest and richest experience of the oldest.

I have said this much to draw your attention to what, 5 in my mind, lies at the root of all this matter, and at the understanding of one another by the men of science on the one hand, and the men of literature, and history, and art, on the other. It is not a question whether one order of study or another should predominate. It is a question of Io what topics of education you shall select which will combine all the needful elements in such due proportion as to give the greatest amount of food, support, and encouragement to those faculties which enable us to appreciate truth, and to profit by those sources of innocent happiness which I5 are open to us, and at the same time, to avoid that which is bad, and coarse, and ugly, and keep clear of the multitude of pitfalls and dangers which beset those who break through the natural or moral laws.

I address myself, in this spirit, to the consideration of 20 the question of the value of purely literary education. Is it good and sufficient, or is it insufficient and bad? Well, here I venture to say that there are literary educations and literary educations. If I am to understand by that term the education that was current in the great majority of 25 middle-class schools, and upper schools too, in this country when I was a boy, and which consisted absolutely and almost entirely in keeping boys for eight or ten years at learning the rules of Latin and Greek grammar, construing certain Latin and Greek authors, and possibly making

30 verses which, had they been English verses, would have been condemned as abominable doggerel-if that is what you mean by literary education, then I say it is scandalously insufficient and almost worthless. My reason for saying so is not from the point of view of science at all, 
but from the point of view of literature. I say the thing professes to be literary education that is not a literary education at all. It was not literature at all that was taught, but science in a very bad form. It is quite obvious that grammar is science and not literature. The analysis of a 5 text by the help of the rules of grammar is just as much a scientific operation as the analysis of a chemical compound by the help of the rules of chemical analysis. There is nothing that appeals to the æsthetic faculty in that operation; and I ask multitudes of men of my own age, ro who went through this process, whether they ever had a conception of art or literature until they obtained it for themselves after leaving school? Then you may say, "If that is so, if the education was scientific, why cannot you be satisfied with it?" I say, because although it is a 15 scientific training, it is of the most inadequate and inappropriate kind. If there is any good at all in scientific education it is that men should be trained, as I said before, to know things for themselves at first hand, and that they should understand every step of the reason of that 20 which they do.

I desire to speak with the utmost respect of that science - philology — of which grammar is a part and parcel; yet everybody knows that grammar, as it is usually learned at school, affords no scientific training. It is taught just as 25 you would teach the rules of chess or draughts. On the other hand, if I am to understand by a literary education the study of the literatures of either ancient or modern nations-but especially those of antiquity, and especially that of ancient Greece; if this literature is studied, not 30 merely from the point of view of philological science, and its practical application to the interpretation of texts, but as an exemplification of and commentary upon the principles of art; if you look upon the literature of a people as 
a chapter in the development of the human mind, if you work out this in a broad spirit, and with such collateral references to morals and politics, and physical geography, and the like as are needful to make you comprehend what 5 the meaning of ancient literature and civilization isthen, assuredly, it affords a splendid and noble education. But I still think it is susceptible of improvement, and that no man will ever comprehend the real secret of the difference between the ancient world and our present time, ro unless he has learned to see the difference which the late development of physical science has made between the thought of this day and the thought of that, and he will never see that difference, unless he has some practical insight into some branches of physical science; and you must I5 remember that a literary education such as that which I have just referred to, is out of the reach of those whose school life is cut short at sixteen or seventeen.

But, you will say, all this is fault-finding; let us hear what you have in the way of positive suggestion. Then I 20 am bound to tell you that, if I could make a clean sweep of everything-I am very glad I cannot because I might, and probably should, make mistakes-but if I could make a clean sweep of everything and start afresh, I should, in the first place, secure that training of the young in read25 ing and writing, and in the habit of attention and observation, both to that which is told them, and that which they see, which everybody agrees to. But in addition to that I should make it absolutely necessary for everybody, for a longer or shorter period, to learn to draw. Now, 30 you may say, there are some people who cannot draw, however much they may be taught. I deny that in toto, because I never yet met with anybody who could not learn to write. Writing is a form of drawing; therefore if you give the same attention and trouble to drawing 
as you do to writing, depend upon it, there is nobody who cannot be made to draw more or less well. Do not misapprehend me. I do not say for one moment you would make an artistic draughtsman. Artists are not made; they grow. You may improve the natural faculty in that 5 direction, but you cannot make it; but you can teach simple drawing, and you will find it an implement of learning of extreme value. I do not think its value can be exaggerated, because it gives you the means of training the young in attention and accuracy, which are the two things 10 in which all mankind are more deficient than in any other mental quality whatever. The whole of my life has been spent in trying to give my proper attention to things and to be accurate, and I have not succeeded as well as I could wish; and other people, I am afraid, are not much I5 more fortunate. You cannot begin this habit too early, and I consider there is nothing of so great a value as the habit of drawing, to secure those two desirable ends.

Then we come to the subject-matter, whether scientific or æsthetic, of education, and I should naturally have no 20 question at all about teaching the elements of physical science of the kind I have sketched, in a practical manner; but among scientific topics, using the word scientific in the broadest sense, I would also include the elements of the theory of morals and of that of political and social life, 25 which, strangely enough, it never seems to occur to anybody to teach a child. I would have the history of our own country, and of all the influences which have been brought to bear upon it, with incidental geography, not as a mere chronicle of reigns and battles, but as a chapter in the 30 development of the race, and the history of civilization.

Then with respect to æsthetic knowledge and discipline, we have happily in the English language one of the most magnificent storehouses of artistic beauty and of models of 
literary excellence which exists in the world at the present time. I have said before, and I repeat it here, that if a man cannot get literary culture of the highest kind out of his Bible, and Chaucer, and Shakespeare, and Milton, and 5 Hobbes, and Bishop Berkeley, to mention only a few of our illustrious writers-I say, if he cannot get it out of those writers, he cannot get it out of anything; and I would assuredly devote a very large portion of the time of every English child to the careful study of the models Io of English writing of such varied and wonderful kind as we possess, and, what is still more important and still more neglected, the habit of using that language with precision, with force, and with art. I fancy we are almost the only nation in the world who seem to think that comI5 position comes by nature. The French attend to their own language, the Germans study theirs; but Englishmen do not seem to think it is worth their while. Nor would I fail to include, in the course of study I am sketching, translations of all the best works of antiquity, or of the 20 modern world. It is a very desirable thing to read Homer in Greek; but if you don't happen to know Greek, the next best thing we can do is to read as good a translation of it as we have recently been furnished with in prose. You won't get all you would get from the original, 25 but you may get a great deal; and to refuse to know this great deal because you cannot get all, seems to be as sensible as for a hungry man to refuse bread because he cannot get partridge. Finally, I would add instruction in either music or painting, or, if the child should 30 be so unhappy, as sometimes happens, as to have no faculty for either of those, and no possibility of doing anything in any artistic sense with them, then I would see what could be done with literature alone; but I would provide, in the fullest sense, for the development of the 
xsthetic side of the mind. In my judgment, those are all the essentials of education for an English child. With that outfit, such as it might be made in the time given to education which is within the reach of nine-tenths of the population-with that outfit, an Englishman, within the 5 limits of English life, is fitted to go anywhere, to occupy the highest positions, to fill the highest offices of the State, and to become distinguished in practical pursuits, in science, or in art. For, if he have the opportunity to learn all those things, and have his mind disciplined in the Io various directions the teaching of those topics would have necessitated, then, assuredly, he will be able to pick up, on his road through life, all the rest of the intellectual baggage he wants.

If the educational time at our disposition were sufficient 15 there are one or two things I would add to those I have just now called the essentials; and perhaps you will be surprised to hear, though I hope you will not, that I should add, not more science, but one, or if possible, two languages. The knowledge of some other language than 20 one's own is, in fact, of singular intellectual value. Many of the faults and mistakes of the ancient philosophers are traceable to the fact that they knew no language but their own, and were often led into confusing the symbol with the thought which it embodied. I think it is Locke who 25 says that one-half of the mistakes of philosophers have arisen from questions about words; and one of the safest ways of delivering yourself from the bondage of words is, to know how ideas look in words to which you are not accustomed. That is one reason for the study of 30 language; another reason is, that it opens new fields in art and in science. Another is the practical value of such knowledge; and yet another is this, that if your languages are properly chosen, from the time of learning the addi- 


\section{24 \\ Selections from Huxley}

tional languages you will know your own language better than ever you did. So, I say, if the time given to education permits, add Latin and German. Latin, because it is the key to nearly one-half of English and to all the Ro5 mance languages; and German, because it is the key to almost all the remainder of English, and helps you to understand a race from whom most of us have sprung, and who have a character and a literature of a fateful force in the history of the world, such as probably has ro been allotted to those of no other people, except the Jews, the Greeks, and ourselves. Beyond these, the essential and the eminently desirable elements of all education, let each man take up his special line-the historian devote himself to his history, the man of science to his science, the I5 man of letters to his culture of that kind, and the artist to his special pursuit.

Bacon has prefaced some of his works with no more than this: Franciscus Bacon sic cogitavit; let sic cogitavi be the epilogue to what I have ventured to address to you 20 to-night. 
NOTES AND COMMENT 



\section{NOTES AND COMMENT}

(Heavy numerals refer to page; light ones to line)

AUTOBIOGRAPHY

(See Introduction pp. xix-xx)

3, 6. Bishop Butler. Joseph Butler (1692-1752), Bishop of Durham, was a writer of great power and influence. His best known work, Analogy of Religion, Natural and Revealed, to the Constitution and Course of Nature, is frequently mentioned by Huxley.

3, ro. Auckland: ten miles south of Durham.

3, 17. Pre-Boswellian epoch: the age in which biography was less personal and prying than it came to be after r79r, when James Boswell (r740-1795) published his Life of Samuel Johnson.

3, 22. "Bene qui latuit, bene vixit." From Ovid: "Whoever has lived unobserved has lived well."

4, 15. Hyde Park Corner: one of the nine gateways to Hyde Park, two and a quarter miles south by west of St. Paul's Cathedral.

4, 30-3r. Mellifluous eloquence: eloquence that flows or drops from the lips like honey. It is said that when Plato was in his cradle a swarm of bees lighted on his mouth. The same story is told of St. Ambrose and St. Dominick.

5, 7-8. That particular Apostle: Thomas, the doubting Apostle, who demanded proof before he would believe. See John $x x, 25$.

6, 9. Prince George of Cambridge: a grandson of George III and Commander-in-chief of the British army.

6, 15-16. Herbert Spencer (1820-1903): one of the greatest philosophers of the nineteenth century. He was an intimate friend of Huxley, to whom he used to send proofsheets of his biological works for criticism. He applied Darwin's theory of evolution to the economic and institutional life of man.

7, ro. Sydney: capital of New South Wales, Australia, visited by Huxley on the voyage of the Rattlesnake. 
7, 23. In partibus infidelium: "among the unfaithful."

8, 9. The disagreeables: a humorous equivalent for the disagreeable things. Compare goods, sweets, bitters.

8, 24. "Sweet south upon a bed of violets." See Twelfth Night, I, I, 5 .

8, 29. "Lehrjahre ": "school-years," or " apprenticeship."

9, 18-19. My first scientific paper. The title was On a Hitherto Undescribed Structure in the Human Hair Sheath. See Introduction ix.

9, 34. Strong: presumptuous.

Io, 22. Haslar Hospital. This famous retreat for invalid sailors is in Gosport, opposite Portsmouth, England.

I2, 22. Middies: abbreviation for midshipmen.

I2, 24. Suites à Buffon: "sequels to Buffon," or "continuations of Buffon's works," a series of scientific monographs published in Paris from 1834 to 1857 . George Louis Leclerc Buffon (1707-1788) was the most celebrated French naturalist of the eighteenth century. He originated the phrase, "Le style est de l'homme," which is usually mistranslated "The style is the man."

12, 28. Noah. See Genesis viii, 7-8.

12, 32. Royal Society: incorporated by Charles II in 1662. Huxley became a member in $185 \mathrm{I}$. See the interesting account of the origin and work of this society in the lecture $O n$ the Advisableness of Improving Natural Knowledge, pages 30-34.

13, 15. Père Goriot: a famous novel by Balzac (1799-1850).

13, I6. "A nous deux": "between us two"; that is, London and I must fight it out.

13, 19. Professor Tyndall. John Tyndall (1820-1893), professor of natural history at the Royal Institution and Fellow of the Royal Society, was an intimate friend of Huxley and famous for his researches in heat, light, sound, and electricity. See Huxley's letters to him, pages 22-24 and page 26 .

13, 28. Edward Forbes. His death in 1853 deprived Huxley of a devoted friend who had already served him in many ways. See Introduction ix-x. Huxley said of him, in 185I: "He is one of the few men I have ever met to whom I can feel obliged without losing a particle of independence or selfrespect."

14, 9-10. On a Friday evening at the Royal Institution, in 1852. The Royal Institution was incorporated by George 
III, January 13, 1800. Its purpose was to facilitate, by lectures and experiments, the application of science to the common needs of daily life. Huxley's experience on this eventful Friday evening is thus told to his sister (Life and Letters, I, I06-107):

"It was the first lecture I had ever given in my life, and to what is considered the best audience in London. As nothing ever works up my energies but a high flight, I had chosen a very difficult abstract point, in my view of which I stand almost alone. When I took a glimpse into the theater and saw it full of faces, I did feel most amazingly uncomfortable. I can now quite understand what it is to be going to be hanged, and nothing but the necessity of the case prevented me from running away.

"However, when the hour struck, in I marched, and began to deliver my discourse. For ten minutes I did not quite know where I was, but by degrees I got used to it, and gradually gained perfect command of myself and of my subject. I believe I contrived to interest my audience, and upon the whole I think I may say that this essay was successful.

"Thank Heaven I can say so, for though it is no great matter succeeding, failing would have been a bitter annoyance to me. It has put me comfortably at my ease with regard to all future lecturings. After the Royal Institution there is no audience I shall ever fear."

14, 10-11. Malgré moi: "in spite of myself."

15, 7. Popularization of science. Huxley's influence in popularizing Darwin's work was recognized by Lord Kelvin, when he presented Huxley with the Darwin Medal in 1894, in these words:

"To the world at large, perhaps, Mr. Huxley's share in molding the thesis of Natural Selection is less well known than is his bold, unwearied exposition and defense of it after it had been made public. And, indeed, a speculative trifler, reveling in the problems of the 'might have been,' would find a congenial theme in the inquiry how soon what we now call 'Darwinism' would have met with the acceptance with which it has met, and gained the power which it has gained, had it not been for the brilliant advocacy with which in its early days it was expounded to all classes of men.

"That advocacy had one striking mark: while it made or strove to make clear how deep the new view went down, and 
how far it reached, it never shrank from trying to make equally clear the limit beyond which it could not go."-Life and Letters, I, 224 .

I5, 10. Ecclesiastical spirit. "The antagonism of science," says Huxley, "is not to religion but to the heathen survivals and the bad philosophy under which religion herself is often well-nigh crushed."

I5, 28. New Reformation. Mrs. Humphry Ward gave this name to the new scientific movement. Huxley, writing to his wife in I873, says: "The part $I$ have to play is not to found a new school of thought or to reconcile the antagonisms of the old schools. We are in the midst of a gigantic movement greater than that which preceded and produced the Reformation, and really only the continuation of that movement. . . . I have no more doubt that free thought will win in the long run than I have that I sit here writing to you."

\section{LETTERS}

(See Introduction, pp. $\mathbf{x x}$-sxi)

I6, x. Miss Heathorn: Miss Henrietta Anne Heathorn, whom Huxley married July I, I855. See Introduction xi.

I6, 5. Naughten: a fusion of naught and nothing.

I7, 3. Sardonic grin. Homer was the first to speak of sardonic laughter, meaning laughter that concealed some evil design. Sardonic still has this sense, but Huxley means by it not malignant but strained, forced, unnatural, not proceeding from real gaiety.

I8, 14. Duke of Wellington. Arthur Wellesley (1769-1852) became successively baron, viscount, earl, marquis, and finally Duke of Wellington. After his victory over Napoleon at Waterloo, he was considered the greatest soldier, as Nelson was the greatest sailor, that England had produced. In the ode to which Huxley alludes in this letter, Tennyson calls Wellington,

"Our greatest yet with least pretense,

Great in council and great in war,

Foremost captain of his time,

Rich in saving common-sense, And, as the greatest only are,

In his simplicity sublime." 
Though he died on September I $_{4}$, he was not buried until November 18.

I8, 17. The Cathedral: St. Paul's. Here lie also Nelson, J. M. W. Turner, Benjamin West, Lord Collingwood, and Sir Joshua Reynolds. The building was completed in 1710. In general impressiveness St. Paul's ranks next to St. Peter's in Rome.

18, 23-24. Marquis of Anglesey. Henry William Paget (1768-1854), first Marquis of Anglesey, commanded the British cavalry at Waterloo.

I9, I. Sir Charles Napier. Charles James Napier (17821853) fought in Wellington's Peninsular campaigns, but was not present at the battle of Waterloo. He completed the conquest of Scinde, a province of western India, by the victory of Hyderabad, March 24, 1843 .

19, 13. Tennyson's ode. The Ode on the Death of the Duke of Wellington was published as a pamphlet of sixteen pages on November 18,1852 , the day of the Duke's funeral. It was revised by Tennyson in 1853, and again in 1855 . The poem has grown steadily in public favor since 1855 .

20, 7. Esau. See Genesis xxv, 20-34. Huxley's writings abound in biblical allusions. See Introduction xvii-xviii.

20, 32. Holmwood: the home of W. M. Fanning in Sydney, Australia, where Huxley met Miss Heathorn, Mrs. Fanning's sister.

2I, 8. Charles Darwin. Charles Robert Darwin (1809-1882), the most famous of English naturalists, was the founder of the biological theory of evolution. His greatest work, $O n$ the Origin of Species by Means of Natural Selection, or the Preservation of Favored Races in the Struggle for Life, was published in 1859. The book marked a turning-point in Huxley's life as well as in the history of biological science. See Introduction xiii, and note on line 7, page 15. As long as Darwin lived he and Huxley were devoted friends and regular correspondents.

21, 13. Von Bär's essays. Karl Ernst von Bär (1792-1876) was a celebrated Russian naturalist, noted especially for his researches in embryology. Huxley ranked him with Darwin, Buffon, and Lamarck. Cuvier he placed "in a somewhat lower rank."

2I, 20. Chapter IX. The chapter headings in The Origin 
of Species, to which Huxley refers, are as follows: I. Variation under Domestication, II. Variation under Nature, III. The Struggle for Existence, IV. Operation of Natural Selection, IX. The Imperfection of the Geological Record, X. The Geological Succession of Organic Beings, XI-XII. Geographical Distribution, XIII. Classification, Morphology, Embryology, and Rudimentary Organs.

2I, 23. Caveat. Liberally, "let him beware." The meaning here is a note of warning or caution.

2I, 27. Onus probandi: "the burden of proof."

22, 3. Natura non facit saltum: "Nature never makes a leap."

22, Io-Ir. Abuse and misrepresentation. Huxley had to bear more of this than Darwin. At the famous Oxford Meeting of 1860 , Bishop Samuel Wilberforce turned to Huxley and asked, "Is it through your grandfather or your grandmother that you claim descent from a monkey?" Huxley's retort (as reported by the historian, John Richard Green) was, "If there were an ancestor whom I should feel shame in recalling it would rather be a man-a man of restless and versatile intellect-who, not content with an equivocal success in his own sphere of activity, plunges into scientific questions with which he has no real acquaintance, only to obscure them by an aimless rhetoric, and distract the attention of his hearers from the real point at issue by eloquent digressions and skilled appeals to religious prejudice."

22, 22. "I think the more." This is the modern form of an old proverb found in John Ray's Compleat Collection of English Proverbs (1742): "Though he says nothing, he pays it with thinking, like the Welshman's jackdaw." In his reply to this letter (November 25, 1859) Darwin says: "I should have been more than contented with one quarter of what you have written."

22, 24. John Tyndall. See note on line 19, page 13.

22, 26. Messina: a seaport of Sicily, ranking next in commercial importance to Palermo.

22, 28. Bence Jones: Huxley's physician.

22, 30. Ray Lankester: Edwin Ray Lankester, professor of comparative anatomy at Oxford since $r 890$ and one of the editors of The Scientific Memoirs of Huxley. See Descriptive Bibliography, xxvii. 
22, 31. Dohrn himself: a German scientist, founder of the Marine Biological Station at Naples. See Introduction xi.

23, 30. Atrio del Cavallo: a large level tract of land separating Vesuvius from Mt. Somma.

24, 2. Élie de Beaumont (1798-1874): a celebrated professor of geology at the Collège de France.

24, 4-5. "Laves mousseuses": lavas permeated with airbubbles, frothy, vain, aspiring lavas. In his article $O n$ the Reception of the Origin of Species (Life and Letters of Charles Darwin, by his son, Francis Darwin, in 3 volumes, $3 \mathrm{~d}$ edition, 1887, vol. II, p. 187) Huxley says: "In France the influence of Élie de Beaumont and of Flourens,-the former of whom is said to have 'damned himself to everlasting fame' by inventing the nickname of la science moussante for Evolutionism . . . produced for a long time the effect of a conspiracy of silence," Huxley is repaying Élie de Beaumont in his own coin.

24, 13. Louis Pasteur (1822-1895) : a famous French chemist and world benefactor, best known for his researches in bacteria, beer, silkworms, and hydrophobia. The Institute which Pasteur established for the treatment of those suffering from the bites of rabid animals was founded in Paris, November 14, I868. Since then similar institutes have been established throughout the world, and the death-rate from hydrophobia has been reduced to less than one per cent.

25, 25. The fanatics of laissez faire: those who advocate the let-alone policy.

25, 29. Prefer that men should suffer than rabbits or dogs. Huxley himself did not practise vivisection, though he considered it justifiable. See Life and Letters, I, 466. It will be noticed that Huxley's English is here defective, rather being necessary after prefer or suffer.

26, 6. Hodeslea. Huxley moved into his new house in December, 1890 . The origin of the name is given by him in a letter of October I5, 1890: "One is obliged to have names for houses here. Mine will be 'Hodeslea,' which is as near as I can go to 'Hodesleia,' the poetical original shape of my very ugly name."

26, 7. Alfred Tennyson (1809-1892). Huxley and Tennyson met rarely but each admired the other. After a visit from Huxley in November, 1871, Tennyson wrote: "Mr. Huxley was charming. We had much talk. He was chivalrous, wide, 
and earnest, so that one could not but enjoy talking with him. There was a discussion on George Eliot's humility. Huxley thought her a humble woman, despite a dogmatic manner of assertion that had come upon her latterly in her writings." Of Tennyson's conversation Huxley said: "Doric beauty is its characteristic-perfect simplicity, without any ornament or anything artificial." He spoke also of "the insight into scientific method" shown in Tennyson's In Memoriam, and pronounced it "equal to that of the greatest experts."

26, 15-16. Between the darkness before and . . after: between birth and death.

26, 19. Lucretius (97-55 B.c.). Nothing definite is known of the life of Lucretius. His great work $O n$ the Nature of Things (De Rerum Natura) consists of six books, the philosophy of which is that all forms of life are due to the chance combination of an infinite number of atoms moving in an infinite void. His descriptions are marked by wonderful accuracy and beauty. Lowell, in his Essay on Chaucer, calls the beginning of Lucretius's poem "the one sunburst of purely poetic inspiration which the Latin language can show."

\section{On the Advisableness of Improving Natural Knowledge}

(See Introduction xxi-xxii)

28, 6. The very spot: St. Martin's Hall, in Long Acre Street, near Drury Lane, London. Defoe says that the first victims were two Frenchmen, who "died of the plague in Long Acre, or rather at the upper end of Drury Lane."

28, 13-14. The History of the Plague Year. Daniel Defoe (1661?-1731) is best known as the author of Robinson Crusoe (1719), but his Journal of the Plague Year (1722) -entitled History of the Plague in the second edition-is equally realistic and minute in its details.

29, 16-17. Of the Republicans, or of the Papists. The Republicans, the party of Cromwell and Milton, wished to abolish monarchy. The Papists were thought to be plotting for the re-establishment of the Catholic faith.

30, 2. The Rochesters and Sedleys: John Wilmot (1647r680), the second Earl of Rochester, and Sir Charles Sedley (r639-170r), noted wits and dramatists in the reign of Charles II. 
30, 6. Laud, or . . Milton. William Laud (1573-1645), Archbishop of Canterbury and supporter of Charles I, attempted to suppress the spread of Puritanism. He was impeached by the Long Parliament and beheaded. John Milton (1608-1674), the author of Paradise Lost and Paradise Regained, was the Latin Secretary to Cromwell and the resolute defender of Puritanism.

30, 28. Copernican hypothesis. Copernicus (1473-1543) proved that the earth revolves around the sun, not (as the old Ptolemaic theory was) the sun around the earth.

30, 32. Selenography of the moon. The last three words are useless. Selenography means the scientific study of the moon.

31, 3. Torricellian experiment. Evangelista Torricelli (1608-1647), a celebrated Italian physicist and friend of Galileo, discovered the principle of the modern barometer.

3r, 10. Galileo . . and Sir Francis Bacon. Galileo Galilei (r $564-1642$ ), a noted Italian astronomer, constructed a thermometer in 1597 and a telescope in 1609. In 1610 he discovered Jupiter's satellites and the spots on the sun. His doctrines were condemned by the Pope and he was compelled to abjure the Copernican theory. Lord Bacon (1561-1626), the celebrated English essayist, scientist, and philosopher, made no important discoveries, but he reformed the method of scientific investigation. $\mathrm{He}$ is, therefore, one of the founders of modern science or the "New Philosophy."

3r, 14. Dr. Wallis: John Wallis (1616-1703), an English grammarian, mathematician, and theologian.

31, 17. Dr. Wilkins: John Wilkins (1614-1672), Bishop of Chester, advocate of the Copernican theory, and one of the founders of the Royal Society.

31, 22. Charles the Second: King of England from 1660 to r685. The following stanza, to which Huxley makes indirect reference, is said to have been written by the Earl of Rochester (see note on line 2, page 30) on the door of Charles II's bedchamber :

"Here lies our sovereign lord the king,

Whose word no man relies on;

$\mathrm{He}$ never says a foolish thing

Nor never does a wise one."

31, 27. Duke of Ormond: James Butler (16ro-1688), the 
first Duke of Ormond, a devoted adherent of Charles II, whom he accompanied into exile.

31, 28-29. Chelsea College. In I664 the Royal Society petitioned Charles II "to grant Chelsea College and the lands belonging to it to the Royal Society." This was done but the college was so out of repair that the Royal Society sold it in I682. It was situated about three miles southwest of St. Paul's Cathedral on the Thames but is no longer in existence. The Society now meets in Burlington House, Piccadilly.

32, 8. Newton. Sir Isaac Newton (1642-1727) was probably the greatest mathematician that ever lived. His most famous work, The Mathematical Principles of Natural Philosophy (Philosophia Naturalis Principia Mathematica), the foundation of modern astronomy, mechanics, and mathematics, was accepted by the Royal Society in 1686 and published in the summer of the following year.

32, 10. Philosophical Transactions: one of the regular publications of the Royal Society, the other being The Proceedings of the Royal Society. The first dates from 1665, the second from 1800 .

32, 28. Vesalius and . . Harvey. Andreas Vesalius (1514-1564) was a noted Belgian anatomist, his Seven Books on the Human Body being epoch-making for his century. William Harvey (1578-1657) was a famous English physiologist, in whose Essay on the Motion of the Heart and the Blood (I628) the circulation of the blood was first demonstrated. His last publication was Essays on Birth (Exercitationes de Generatione, 165 i).

32, 29. Grain of mustard seed. See Mattherw xiii, 3I-32, and Mark iv, 3T-32.

33, 5. Schoolmen: philosophers of the Middle Ages, many of whose speculations were useless and absurd.

33, 11. "Writ in water." The epitaph on Keats's tombstone in Rome, composed by himself, is: "Here lies one whose name was writ in water."

33, 13. First President: Lord Brouncker, mentioned below. He was the first to hold office after the formal incorporation of the Royal Society, July 15, 1662.

33, 31. Revenant: French for ghost, returning spirit.

34, Io-rr. Mr. Hooke: Robert Hooke (1635-1703), an English mathematician. 
34, 28. A Boyle, an Evelyn, and a Milton. Robert Boyle (1627-169r), an English chemist, is best known as the discoverer of Boyle's law of the elasticity of air and as the founder of Boyle's Lectures for the Defense of Christianity. John Evelyn (1620-1706) was a secretary of the Royal Society, but is remembered chiefly by his letters and diary. For Milton, see note on line 6 , page 30 .

34, 3x. Restoration: the restoration of Charles II to the English throne in 1660, after the Commonwealth of Cromwell. 35, 3. Only. The more logical position would be before among.

35, 4-5. Unswept and ungarnished. See Luke xi, 25.

$35,7-8$. Note the studied repetition and parallelism in these two lines. See also lines $\mathrm{I}-8$ on page 46 .

37, 11. Blind leaders of the blind. See Matthew $x v, 14$.

37, 25. Aladdin's lamps: the source of illimitable power. See Aladdin or the Wonderful Lamp in the Arabian Nights' Entertainments.

37, 26-27. Thank God they are better. See Luke xviii, II. 39, ro. "When in heaven the stars": from Tennyson's Specimen of a Translation of the Iliad in Blank Verse (Iliad, VIII, 542-56I). See note on line 7 , page 26 .

40, 30. "Increasing God's honor." In The Advancement of Learning Bacon says that knowledge is to be pursued "For the glory of the Creator and the relief of man's estate."

42, 2-3. The discovery of oxygen: by Joseph Priestley ( $1733-1804$ ) in 1774 .

42, 12. Count Rumford. Benjamin Thompson (1753-1814), Count Rumford, was an American scientist and political adventurer who spent most of his active life in England and Germany. He was a member of the Royal Society and one of the founders of the Royal Institution (see note on lines 9-10, page 14). He left to Harvard University funds for the establishment of the Rumford Professorship.

.43, 3I-32. By worship "for the most part of the silent sort." The thought, if not the form, is from Carlyle, who in his Heroes and Hero-IVorship constantly emphasizes the duty of silence in worship and work.

43, 32. At the altar of the Unknown. See Acts xvii, 23.

45, II-12. Skepticism is the highest of duties. This is not an attack on religion. "The antagonism between science and 
religion appears to me," said Huxley, "to be purely factitious, fabricated on the one hand by short-sighted religious people; and on the other by equally short-sighted scientific people." See

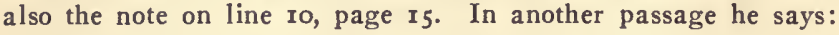
"When I say that Descartes consecrated doubt, you must remember that it was that sort of doubt which Goethe has called 'the active skepticism, whose whole aim is to conquer itself'; and not that other sort which is born of flippancy and ignorance, and whose aim is only to perpetuate itself, as an excuse for idleness and indifference."

\section{A Liberal Education: and Where to Find It (See Introduction xxii-xxiii)}

48, 5. Ichabod. See $I$ Samuel iv, $2 \pi$.

48 , ro. The people perish for lack of knowledge. Hosea iv, 6: "My people are destroyed for lack of knowledge."

49, 22. Our public schools. These are not to be confounded with our American public schools. Huxley had in mind such schools as Rugby and Eton.

49, 29. Senior wranglership, or a double-first. These are English academic terms, the first meaning the highest honors in mathematics at Cambridge University, the second the highest honors in mathematics and the classical languages at $\mathrm{Ox}$ ford University.

5I, I. Raveled skein. To ravel is one of the few verbs in English that may mean two contradictory things: to tangle or to untangle. Huxley uses it in the first sense.

5I, 18. Gambit: an opening play by which a pawn is sacrificed to gain a better position.

52, 10. Retzsch: Friedrich August Moritz Retzsch (17791857), a German etcher and painter.

53, 29. Test-Acts. The English Test-Act of 1673 , repealed in 1828 , forbade any one to hold public office who did not swear loyalty to the Church of England.

53, 33. The "Poll": students who pass (get through) but take no honors. The term is in vogue at Cambridge University and is derived from the Greek of $\pi 0 \lambda \lambda$ l, "the many," "the mass."

54, 1. Plucked: pitched, "flunked," dropped from the roll.

56 , 2. Law of the inverse squares. According to this law 
the attraction of two bodies varies inversely as the square of the distance.

56, 7. The hundred: a division of the county, not very different from our township.

56, 22. Falstaff's bill. See I Henry IV, II, iv, 550.

57, 20-21. "Circumbendibus": a humorous formation from circum + bend with the ending of a Latin ablative plural and meaning circumlocution. The word seems to have been coined by Dryden in r681. As here used "a thief with a circumbendibus" is equivalent to "another name for thief."

60, 8. Euclid. The Elements of Geometry by Euclid (about 300 B.c.) is still used as a text-book and the name of Euclid has become a synonym for geometry.

60, 31-32. Chaucer, Shakespeare . . Schiller. Geoffrey Chaucer (1340-1400), the first great English poet and the author of many books, is best known through The Canterbury Tales, the supreme masterpiece of Middle English. William Shakespeare (1564-1616) needs no comment. For Milton, see note on line 6, page 30. François Marie Arouet Voltaire (1694-1778), the last being an assumed name of unknown origin, was the most versatile, prolific, and influential writer that France has produced, the best edition of his works numbering seventy-two volumes. Johann Wolfgang von Goethe (1749-1832) and Johann Christoph Friedrich von Schiller (1759-1805) are the two greatest names in German literature, Goethe being probably the most fruitful thinker of modern times.

6I, 4. The few righteous. See Genesis xviii, 23-32.

62, 7-8. Tasmania . . New South Wales. The first, discovered by Tasman in 1642 , is an island and British colony in Australasia. It was a dependency of New South Wales until 1825. The second, named from a fancied resemblance to the northern shores of the Bristol Channel, is a British colony in Australia. Huxley spent several years in Sydney, the capital of this colony.

62, 17. Crœsus: a Lydian king who lived about $55^{\circ}$ B.C., and whose name has become a synonym for boundless wealth.

64, 3. A Niebuhr, a Gibbon, or a Grote? Paleontology is a branch of biology, both dealing constructively with the former life of the globe. In each of these great paleontologists, therefore, Huxley hails a kindred spirit. Barthold Georg Niebuhr 
(1776-1831), a German historian, reconstructed our ideas of ancient history in his History of Rome. Edward Gibbon (1737-1794), the English historian, did an equal service for later Roman history in his Decline and Fall of the Roman Empire. George Grote (1794-187r), also an Englishman, wrote an authoritative History of Greece. Huxley commended the example of Grote and Faraday in declining all titular honors offered them by the government.

65, 13-14. Cicero, or Horace. Marcus Tullius Cicero (ro643 B.c.), the Roman critic, orator, and philosopher, is here cited as the exemplar of the purest Latin prose, and Quintus Horatius Flaccus $(65-8$ B.c.) as the poet of the purest lyric style in Roman literature.

65, 14. Sixth form: the senior class in an English public school.

65, 15. Terence. Publius Terentius Afer (I85-159 B.c.) was the master of Latin comedy.

65, 30. Parnassus: classical studies. Parnassus, a mountain ridge in Greece, was the fabled abode of the Muses.

66, 22. These be your gods. See Exodus xxxii, 4.

$66,27$. This is the stone he offers. See Mattherv vii, 9 .

66,31 .This is an awful subject: perhaps a reminiscence of Burke's "Surely it is an awful subject" (beginning of the second paragraph of his speech on Conciliation with America.

67, 3. Rector of Lincoln College: Mark Pattison (18131884), referred to below.

69, 17-19. Grote . . Mill . . Faraday . . Robert Brown . . Lyell . . Darwin. For Grote, see note on line 3, page 64. John Stuart Mill (1806-1873), a celebrated English logician and political economist. Michael Faraday (1791-1867), an English chemist, famous for his discoveries in electricity and magnetism. Robert Brown (1773-1858), an English botanist. Sir Charles Lyell (1797-1875), an English geologist, author of Principles of Geology, Elements of Geology, and The Antiquity of Man. For Darwin, see note on line 8 , page $2 \mathrm{r}$.

70, 34. La carrière ouverte aux talents. "For I take it that the real essence of democracy was fairly enough defined by the First Napoleon when he said that the French Revolution meant 'la carrière ouverte aux talents'-a clear pathway for merit of whatever kind" (Lowell's Democracy). 
7I, x. Bursch: a German student.

72, 2x. "Erdkunde ": "earth-knowledge."

\section{On a Piece of Chalk}

(See Introduction, pp. xxiii-xxiv)

[A map should be used in the study of this lecture.]

74, 17. Albion: literally "white land," so called from the chalk cliffs of the southern coast.

74, 26. Weald. The Weald (pronounced wield and meaning originally the wilds) is an oval-shaped area bounded by a line that begins near the Straits of Dover and passes through the counties of Kent, Surrey, Hants, and Sussex, meeting the sea again at Beachy Head.

76, 29-30. Though ignorant of all other history. Could not this clause be better placed? Try it after that or man or know in line 27 .

77, 31-32. Stalagmites and stalactites. Both are conelike, but the former rise from the floor of the cavern while the latter hang from the roof.

78, 13. Laminated: having lamina, that is, thin plates or scales.

80,4 . Globigerina. The second $g$ is pronounced as $j$ and the accent is on the next to the last syllable, the $i$ having the usual English long sound.

81, 7. Lieut. Brooke: John Mercer Brooke (1826-1906), the inventor also of the Brooke gun.

81, 16. Ehrenberg: Christian Gottfried Ehrenberg (17951876), a German naturalist, noted for his study of minute water-plants and animals.

81, 17. Bailey: Jacob Whitman Bailey (1811-1857), a West Point graduate and professor.

81, 25. Telegraph-cable. Cyrus W. Field (1819-1892), of New York, stretched a cable from the American coast to Newfoundland in 1856 . Ten years later he continued it to England. 8I, 32. Captain Dayman: one of the lieutenants of the Rattlesnake. See Introduction ix.

85, 30. Star-fish. Notice that in this note Huxley uses the two plurals, star-fish and star-fishes $(86,28)$, interchangeably. 
85, 33. Dr. Wallich: George Charles Wallich (1815-1899), an English authority in marine biology.

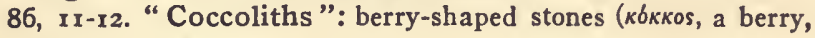
$+\lambda($ Oos, a stone $)$.

86, 16. "Coccospheres": a round mass of coccoliths (кбккоs,

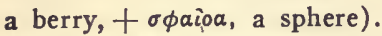

86, 19. Mr. Sorby: Henry Clifton Sorby (1826- ), a fellow of the Royal Society and later president of Frith College, Sheffield.

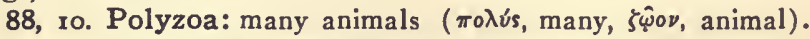
The singular is polyzoön, sometimes polyzoum (Latin).

88, Ir. Brachiopoda: arm-footed ( $\beta \rho a \chi i \omega \nu$, arm, $+\pi b u s\left(\pi 0 \delta_{-}\right)$, foot).

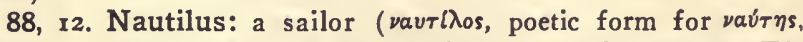
sailor). See Oliver Wendell Holmes's popular poem, The Chambered Nautilus.

90, 8. Lyell. See note on lines $\mathbf{7} 7-\mathbf{r g}$, page 69.

93, r. Hoxne . . Amiens. The first is in Suffolk, England, the second in northern France. As early as 1800 rude flint instruments, belonging to prehistoric man, were unearthed in both places.

94, 7. Rev. Mr. Gunn: Robert Campbell Gunn (1808-1881), a noted English naturalist. He emigrated to Tasmania at the age of twenty-one and helped to found the Royal Society of Tasmania.

94, 15. Writing upon the wall. See Daniel v, 5.

94, 22. "The whirligig of time." See Twelfth Night, V, r, 379.

95, 28. "The river of Babylon." This phrase does not occur in the Bible; but the Euphrates, on which Babylon was situated, is called "the great river" in Genesis $x v, 18$.

97, 14. Australia. The zoology of Australia and Tasmania is in many respects different from that of any other region.

98, 5-6. Pterodactyl . . . ich thyosaurus . . plesiosaurus. The first means wing-fingered ( $\pi \tau \epsilon \rho \delta \nu$, wing, $+\delta \dot{\alpha} \kappa \tau u \lambda o s$, finger), the second fish-lizard (lॄous, fish, + oavpos, lizard), the third near-lizard ( $\pi \lambda \eta \sigma l o s$, near, $+\sigma a$ ivpos, lizard). Note that the prefix plesio- in scientific terms is exactly analogous to the prefix near in such humorous compounds as near-beer, nearpoetry, etc. 
98, 23-24. Foraminifera: hole-bearing organisms (Latin foramen (foramin-), a hole, +ferre, to bear).

98, 28. Lamp-shell. These all belong to the family of the terebratúlida, or bored-through organisms (Latin terebrare, to bore).

98, 32-33. Diminished head. See Milton's Paradise Lost, iv, 33-34:

\section{"At whose sight all the stars}

Hide their diminished heads."

99, I. Battle of Hastings. In this battle, fought October 14, 1066, the Normans under William the Conqueror defeated the Saxons or English under King Harold.

Ioo, 23. "Older tertiary." With the coming of life the geological record is classified into four divisions: 1 . The Primary or Palæozoic (ancient life) Period, 2. The Secondary or Mesozoic (middle life) Period, 3. The Tertiary or Cainozoic (recent life) Period, 4. The Quaternary or Post-Tertiary Period.

I02, I-2. "Without haste, but without rest." This was one of Huxley's favorite quotations from Goethe. See Sprüche in Reimen: Zahme Xenien, II. J. S. Blackie translates the complete passage as follows:

"Like the star

That shines afar,

Without haste

And without rest,

Let each man wheel with steady sway

Round the task that rules the day,

And do his best."

\section{On Science and Art in Relation to Education (See Introduction, p. xxiv)}

103, 5. In the Gospel. See Matthew xxii, 2-IO.

I04, 6. "Hansardization": the process of comparing a man's past and present records. Luke Hansard (1752-1828) was the official printer of the English parliamentary reports.

105, 12. To particularly emphasize. Note the so-called "split infinitive." There are cases where this idiom is justified by the demands of euphony or clearness, but this hardly seems one of them. 
I05, 28. Cerberus: the three-headed watch-dog at the entrance to the infernal regions. See Swift's reference in his lines On Poetry:

"To Cerberus they give a sop,

His triple barking mouth to stop."

I06, 10-Ir. Nothing human comes amiss to it: a reference to the famous saying of Terence: "I am a man, and I consider nothing human foreign to me" ("Homo sum; humani nihil a me alienum puto").

107, 34. Clifton: Clifton College, in Gloucestershire, one mile west of Bristol.

I09, 34. Mr. Freeman: Edward Augustus Freeman (18231892), author of the famous History of the Norman Conquest.

IIO, I5. The be-all and end-all: the sum total. See Macbeth I, vii, 5 .

IIO, 19-20. William Harvey. See note on line 28, page 32. I12, 23. The rub. See Hamlet III, i, 65.

II3, 26. Francis Bacon. See note on line ro, page 31. The reference is probably to a sentence in Bacon's Latin essay on Promptitude: "He who errs quickly is quick in correcting the error" ("Qui cito errat, cito errorem emendat").

II6, 24. Sebastian Bach: Johann Sebastian Bach (1685r750), a German musician, who shares with Händel the honor of being the Shakespeare of the fugue.

II7, 20. Shakespeare . . Goethe. See note on lines $3^{\text {I- }}$ 32 , page 60 .

II7, 26. Intellectual content. This is a truth of prime importance at all times but especially now when literature is popularly regarded as merely a dainty pastime. David Masson expresses the same truth as follows: "Every artist is a thinker, whether he knows it or not; and ultimately no artist will be found greater as an artist than he was as a thinker."

122, 4. Chaucer and Shakespeare. See note on lines $3^{\mathrm{r}-}$ 32, page 60 .

122, 4. Milton. See note on line 6, page 30.

122, 5. Hobbes and Bishop Berkeley. Thomas Hobbes (1588-1679), an English philosopher, advocated in his Leviathan the doctrine that the power of the state over the individual is absolute. George Berkeley (1685-1753), an Irishman and Bishop of Cloyne, believed that there is no such thing as matter but that everything is spirit. Of Berkeley's doctrine of 


\section{Notes and Comment}

idealism Huxley wrote: "It is that idealism which declares the ultimate fact of all knowledge to be a consciousness, or in other words, a mental phenomenon; and therefore affirms the highest of all certainties, and indeed the only absolute certainty, to be the existence of mind."

123, 25. Locke: John Locke (1632-1704), an English philosopher and author of an Essay Concerning the Human Understanding.

124, 18. Franciscus Bacon. See note on line ro, page 3 r. The meaning of the sentence is "Thus thought Francis Bacon"; sic cogitavi means "thus I thought." 


\section{QUESTIONS AND TOPICS FOR STUDY}

Before taking up these questions let us read some of the things that have been said about Huxley's writings. Do not accept blindly the opinions of others but compare your own impressions with theirs. If they say something that you had not thought of, do not accept it or reject it until you have tested it by a more careful reading of Huxley himself. Above all do not be satisfied with mere words or phrases. Seek for illustrations in Huxley's writings of every point made for or against him. Mrs. Huxley, for example, edited a small volume of selections from her husband's writings and prefaced it with these words: "Some of the passages were picked out for their philosophy, some for their moral guidance, some for their scientific exposition of natural facts, or for their insight into social questions; others for their charms of imagination or genial humor, and many-not the least-for their beauty of lucid English writing." Can you illustrate each of these points by sentences or paragraphs from the selections that you have read? The attempt to do so would greatly increase your appreciation of the distinctive excellences of Huxley's writings.

Huxley's scientific friend, E. Tay Lankester, wrote of him as follows: "In Professor Huxley's work . . . we never miss his fascinating presence; now he is gravely shaking his head, now compressing the lips with emphasis, and, from time to time, with a quiet twinkle of the eye, making unexpected apologies, or protesting that he is of a modest and peaceloving nature. . . Everything which has entered the author's brain by eye or ear . . . comes out again to us clarified, sifted, arranged, and vivified by its passage through the logical machine of his strong individuality." Can you find passages that help you to visualize Huxley as Lankester has visualized him?

A writer in a leading American magazine criticised Huxley's 
essays as follows: "In form his essays are often rambling, sometimes disconnected, occasionally prolix. He plunges into the midst of a subject and, discovering there an almost limitless number of things which are apropos of the last thing he said, frequently skips about hither and thither, trusting to good luck and his own mother wit to guide him safely to some suitable conclusion." From what you have read of Huxley do you consider this a just criticism?

\section{Autoblography (pages $3^{-1} \mathbf{5}$ )}

Autobiography is a modern form of literature. A study of the greatest autobiographies will show that they grew out of the desire not so much to perpetuate the names of the writers as to be helpful to others. A typical example is Benjamin Franklin's Autobiography. Huxley's Autobiography, which was written to take the place of a merely formal sketch of his life by another, is the shortest autobiography on record and is not as intimate a revelation as most autobiographies are.

x. How many paragraphs are devoted to merely introductory matter? How many to the conclusion?

2. Name some important events in Huxley's life omitted in the Autobiography.

3. What does Huxley say are the two objects that he has "had more or less definitely in view" (page 14)? Enumerate some of his achievements under each of these heads. (See Introduction xiii-xix.)

4. Cite examples of humor in the Autobiography. Of exaggeration.

5. Explain the hope expressed in the last sentence of the last paragraph.

\section{LETTERS（pages r6-27)}

Of all the kinds of discourse letters are the freest and most informal. They should not leave the impression that they were written with too great pains or with too minute consideration of words or sentences. They should be fresh, unstudied, spontaneous. They should suggest a conversation rather than an essay. In fact, the letter is a sort of long- 
I48 Questions and Topics for Study

distance conversation. Letters are interesting also not only because they contain autobiographical material but because they frequently throw light on the times in which they were written. Huxley's letters serve both of these ends.

\section{To Miss Heathorn (pages $16-18$ )}

x. Express in your own language how Huxley felt about the Royal Medal.

2. How was it the "turning-point" of his life?

\section{To Miss Heathorn (pages 18-19)}

x. Does Huxley attempt to tell what happened at the funeral or only what he saw and felt?

2. Had he been writing an essay instead of a letter, how would he have treated the subject?

3. Read Tennyson's Ode on the Death of the Duke of Wellington and pick out some of the passages that you think Huxley marked.

\section{To Miss Heathorn (pages $\mathrm{x9-2 \textrm {x } )}$}

$x$. What "three years" does Huxley mean?

2. What difference between man's love and woman's love does Huxley dwell upon in this letter?

\section{To Charles Darwin (pages 21-22)}

x. Why is 1859 one of the most significant dates in Huxley's life?

2. What were the relations between Huxley and Darwin?

\section{To John Tyndall (pages 22-24)}

x. Which of the first two paragraphs gives you the clearex picture of the scenes described?

2. Reproduce the picture in your own language.

3. Explain the reference to Élie de Beaumont. 


\section{Questions and Topics for Study}

\section{To the Lord Mayor of London (pages 24-26)}

I. Is this a real letter, or is it the outline of the speech that Huxley would have delivered if he could have attended the meeting?

2. What two kinds of service had Pasteur rendered?

\section{To John Tyndall (page 26)}

x. How did the sunshine suggest Tennyson's poems?

2. Can you name any poem or cite any passages in which Tennyson shows his familiarity with science?

\section{To a Young Man (pages 26-27)}

r. Write the letter that you suppose the young man wrote.

2. What sentence in Huxley's letter puts drudgery in a new light?

3. What does the Scotch proverb mean?

\section{On the Advisableness of Improving Natural Knowledge (pages 28-46)}

The selections that follow, whether called lay sermons, addresses, or lectures, are really essays and were so considered by Huxley when he included them in his Collected Essays. There are, however, two kinds of essay, - the chatty, humorous, personal essay as written by Addison, Steele, Lamb, and Thackeray, and the more carefully constructed and more seriously expository essay as written by Macaulay, Carlyle, Arnold, and Lowell. Huxley's essays belong to the second class: they are studied attempts to expound important truths. It will be found that each essay presents some central thought or thoughts. Each essay, in other words, has unity. It will be found also that the structure of each essay is determined solely by the desire to present these central thoughts as clearly and as vividly as possible. The questions that follow, therefore, are intended to help you to appreciate, (x) the thoughtcontent of each essay, and (2) the architecture by which the thought-content is made clear. 
I. What are the two central thoughts in this essay (see especially pages 38 and 44 )?

2. What are some of the "great ideas" that you have obtained from science (botany, physiology, physics, or chemistry) ?

3. How does Huxley use the "two fearful calamities" to introduce the subject of this essay?

4. Does the conclusion (page 45 , line 27 to close) merely sum up, or does it make an appeal, or does it do both?

\section{A Liberal Education: and Where to Find It (pages 47-73)}

r. What two questions does Huxley endeavor to answer in this essay (see especially pages $5 \mathrm{I}$ and 55 )?

2. Memorize the answer to the first question as given in the paragraph on pages 54-55.

3. Where did Huxley think a liberal education could be found?

4. If you do not play chess, see if you cannot substitute some game that you do understand in place of the metaphor employed in the paragraph on pages 5i-52.

5. What is the subject discussed in the introductory part of this essay (see end of page 50 and beginning of page $5 \mathrm{I}$ )? How do these introductory remarks lead up to the essay proper?

\section{On a Piece of Chalk (pages 74-ro2)}

r. What is the great lesson which, 'after much deliberation' (page 76), Huxley endeavors to teach by a piece of chalk?

2. How does he show (I) "that we have as strong grounds for believing that all the vast area of dry land, at present occupied by the chalk, was once at the bottom of the sea, as we have for any matter of history whatever" (pages 8889 ); (2) "that the chalk sea existed during an extremely long period" (page 92); and (3) "that the earth, from the time of the chalk to the present day, has been the theater of a series of changes as vast in their amount, as they were slow in their progress" (pages 95-96)?

3. What is the purpose of the introductory part of this essay?

4. With what striking comparison does Huxley close the essay? 


\section{Questions and Topics for Study I 5 I}

On Science and Art in Relation to Education (pages 103-124)

x. What are the four "points which must be attended to" (page 109 ) in the teaching of science?

2. Into what two groups does Huxley classify "all our mental furniture" (page II4)?

3. Why do music, painting, and literature belong to both groups?

4. What kind of training would Huxley give if he "could make a clean sweep of everything and start afresh" (page I20)?

5. What defense of himself does Huxley make in the introductory part of this essay (to page 107, line 12) ?

6. What is the effect of the concluding short paragraph ? 



\section{IEnglísb TReadings for ฐcbools}

Wilbur L. Cross, Yale University, General Editor

Addison: Sir Roger de Coverley Papers.

Edited by Nathaniel E. Griffin, Princeton University.

Arnold: Sohrab and Rustum, and Other Poems.

Edited by Walter S. Hinchman, Groton School.

Browning: Selections.

Edited by Charles W. Hodell, Goucher College, Baltimore. Bunyan: Pilgrim's Progress, Part I.

Edited by John H. Gardiner.

Burke: On Conciliation.

Edited by Daniel V. Thompson, Lawrenceville School.

Byron: Prisoner of Chillon and Other Poems.

Edited by Hardin Craig, University of Minnesota.

Carlyle: Essay on Burns.

Edited by Sophie C. Hart, Wellesley College.

Defoe: Robinson Crusoe.

Edited by WILbUR L. Cross, Yale University.

Dickens: Tale of Two Cities.

Edited by E. H. Kemper McСомв, Manual Training High

School, Indianapolis, Ind.

Eliot: Silas Marner.

Edited by Ellen E. Garrigues, De Witt Clinton High

School, New York City.

English Lyrics from Dryden to Burns.

Edited by MORris W. Croll, Princeton University.

Franklin: Autobiography.

Edited by Frank W. Pine, Gilman Country School, Baltimore.

Hughes: 'Tom Brown's School Days.

Edited by W. H. Lillard, Phillips Andover Academy.

Huxley: Selections.

Edited by Charles Alphonso Smith, University of Virginia. Irving: Sketch Book.

Edited by ARthur W. Leonard, Phillips Academy, Andover, Mass.

Macaulay: Life of Johnson.

Edited by Chester N. Grzenough, Harvard University.

Macaulay: Lord Clive and Warren Hastings.

Edited by Frederick E. Pierce, Yale University, and Samuel Thurber, Jr., Technical High School, Newton, Mass. 
Milton: L'Allegro, Il Penseroso, Comus, and Lycidas. Edited by Martin W. Sampson, Cornell University.

Old Testament Narratives.

Edited by George H. NetTleton, Yale University.

Scott: Quentin Durward.

Edited by Thomas H. Briggs.

Scott : Ivanhoe.

Edited by Alfred A. MaY, High School of Commerce, New York City.

Scott: Lady of the Lake.

Edited by Alfred M. Hitchcock, Public High School, Hartford, Conn.

Shakespeare: Macbeth.

Edited by Felix E. Schelling, University of Pennsylvania. Shakespeare: Merchant of Venice.

Edited by Frederick E. Pierce, Yale University.

Shakespeare: Julius Cæsar.

Edited by Ashley H. Thorndike, Columbia University. Shakespeare: As You Like It.

Edited by JoHN W. CunLiffe, Columbia University, and GeORge RoY ELLlotT, University of Wisconsin.

Stevenson: Inland Voyage and Travels with a Donkey.

Edited by EDwin Mims, Vanderbilt University.

Stevenson: Treasure Island.

Edited by Stuart P. Sherman, University of Illinois.

Tennyson: Idylls of the King.

Edited by JOHN ERSKINE, Columbia University.

Thackeray: English Humorists.

Edited by William Lyon Phelps, Yale University.

Washington: Farewell Address, with Webster: First Bunker Hill Oration. Edited by Wrlliam E. Simonds, Knox College, Galesburg, Ill.

Wordsworth: Selections. Also from Coleridge, Shelley, and Keats. Edited by JAMES W. LiNN, University of Chicago.

\section{HENRY HOLT AND COMPANY, PUBLISHERS}



UNIVERSITY OF CALIFORNIA LIBRARY

\section{Los Angeles}

This book is DUE on the last date stamped below. 


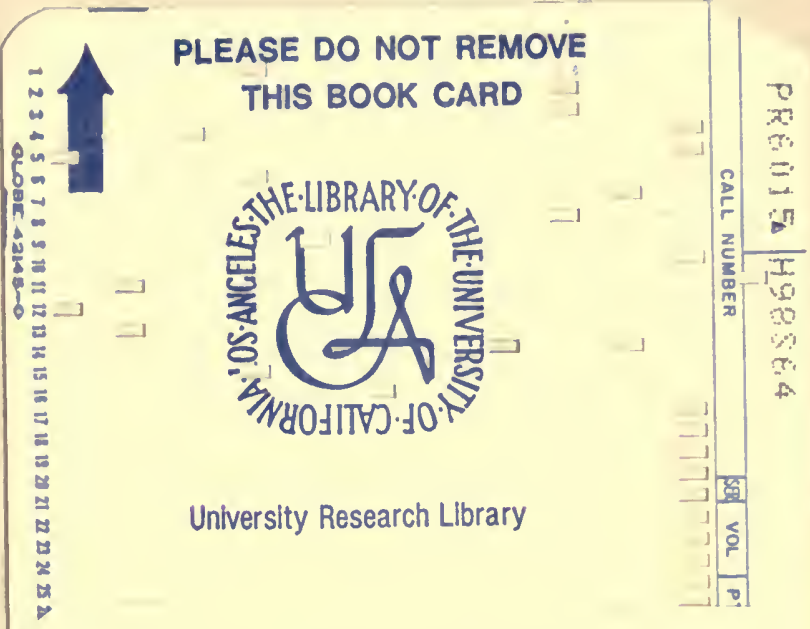


